\title{
IDENTIFICAÇÃO DE QTLs NOS CROMOSSOMOS 2 E 4 QUE CONTROLAM CARACTERÍSTICAS DE DESEMPENHO E CARCAÇA EM AVES (Gallus gallus)
}

\author{
ERICA ELIAS BARON \\ Zootecnista
}

Orientador: Prof. Dr. LUIZ LEHMANN COUTINHO

Tese apresentada à Escola Superior de Agricultura "Luiz de Queiroz", Universidade de São Paulo, para obtenção do título de Doutor em Agronomia, Área de Concentração: Ciência Animal e Pastagens.

PIRACICABA

Estado de São Paulo - Brasil

Agosto - 2004 
ERRATA:

ERICA ELIAS BARON. Idenificação de QTLs nos cromossomos 2 e 4 que controlam caracteristicas de desempenho e carcaça em aves (Gallus gallus)

\begin{tabular}{|c|c|c|c|c|}
\hline p. & item & parágrafo & linha & onde se lê \\
\hline$x$ & 15 & & segunda & $\begin{array}{l}\text {... e carcaça que tiveram ligação } \\
\text { sugestiva na análise de "linecross" ... }\end{array}$ \\
\hline$x$ & 16 & & segunda & $\begin{array}{l}\text {... e carcaça que tiveram ligação } \\
\text { sugestiva na análise de "halfsib" ... }\end{array}$ \\
\hline xii & resumo & & vigésima primeira & $\begin{array}{l}\text {...consistentes com os publicados em } \\
\text { outras espécies. }\end{array}$ \\
\hline 2 & introdução & & décima segunda & $\begin{array}{l}\text {...a seleção para caracteres com fácil } \\
\text { identificação fenotipica ... }\end{array}$ \\
\hline 8 & 2.2 .1 & sexto & sexta & ... de populaçōes "outbred"pequenas... \\
\hline 13 & 2.3 & & Tabela 1. & ${ }^{\star}$ Recombinantes que são informativos... \\
\hline 17 & 2.5 & quarto & quinta e sexta & $\begin{array}{l}\text {.. onde pelos genótipos claramente } \\
\text { pode-se inferir os fenótipos extremos. }\end{array}$ \\
\hline 18 & 2.5 & sexto & nona & $\begin{array}{l}\text {... experimento inclui várias } \\
\text { caracteristicas ou... }\end{array}$ \\
\hline 20 & 2.6 .2 & segundo & segunda & ... entre os alelos o marcador.... \\
\hline 30 & 3.6 & & Tabela 2. & n. alelos \\
\hline 31 & 3.6 & & Tabela 3. & n. alelos \\
\hline
\end{tabular}

33 terceiro quarta

$34 \quad 3.8 \quad$ quarto décima primeira

... para a caracteristica de peso vivo aos 42 dias da população.

leia-se

... e carcaça na análise de "linecross" ...

.. e carcaça na análise de "halfsib" ...

...consistentes com os publicados em outras populaçōes.

....a seleção para caracteres com dificil identificação fenotipica ...

... de populações não endogâmicas pequenas...

*Recombinantes que não são informativos...

... onde pelos fenótipos extremos claramente pode-se inferir os genótipos.

... experimento inclui várias caracteristicas não altamente correlacionadas ou...

... entre os intervalos dos marcadores ...

n.alelos descritos para o marcador

n.alelos descritos para o marcador

... para todas as caracteristicas coletadas da população.

... análise de correlação das 19 caracteristicas pelo procedimento "CORR"do SAS...

... análise de correlação fenotipica das 19 caracteristicas pelo procedimento "CORR" do SAS e uma análise de correlação genotipica realizada por Melo et al. (2004) utilizando-se o programa REMLF90 (Misztal, 1999)

$\begin{array}{lllll}40 & 3.14 & \text { primeiro } & \text { décima terceira } & \ldots \text { p. para um total de } k \text { grupos. } \\ 40 & 3.16 & \text { primeiro } & \text { segunda } & \ldots \text { significativos }(P>0,10) \text {, associados... } \\ 42 & 3.17 & \text { segundo } & \text { nona e décima } & \begin{array}{l}\ldots \text { marcadores com melhores } \\ \text { recombinaçōes ... }\end{array}\end{array}$

$43 \quad 3.18$

$\begin{array}{llll}46 & 3.19 & \text { nono } & \text { segunda } \\ 55 & 4.5 & & \text { Tabela } 8 . \\ 55 & 4.5 & & \text { Tabela } 8 . \\ 60 & 4.7 & & \text { Tabela 11. } \\ 61 & 4.7 & & \text { Tabela 13. } \\ 62 & 4.8 & \text { terceiro } & \text { primeira } \\ 66 & 4.8 & & \text { Figura 4, sétima }\end{array}$

72 Conclusão terceiro oitava

... como covariáveis os pesos vivos ao
nascer, aos 35 dias e aos 42 dias de
idade, de acordo com a caracteristica
influenciada por esses pesos.
influenciada por esses pesos.

... de QTLs pelo programa QTL Express...

Não significativo

Significativo a $\mathrm{n} \%$ ( $\mathrm{n}$ indica os diferentes valores)

Fam = número de familias

Posição obtida no CRI-MAP (cM)

... QTLs significativos a $1 \%$ no...

1) $F I F W=$ consumo... (incluir)

Para nossa estrutura populacional...no genoma.
... para um total de $k$ classes genotipicas.

... significativos $(P<0,10)$, associados...

... marcadores com maior número de meioses informativas ...

...como covariáveis: 1) o peso vivo ao nascer para as caracteristicas PV42, PV35 e PV41; 2) o peso vivo aos 42 dias para peso da cabeça, pés, figado, coração, moela, comprimento do intestino, asa, coxa, peito, costas, gordura abdominal e pulmão; 3 ) o peso vivo aos 35 dias para ganho de peso, consumo de ração, conversão alimentar e eficiência alimentar medidos no intervalo de 35 à 41 dias.

... de QTLs pelo programa descrito por De Koning et al. (1999)...

$(P>0,10)$

$(P<0,10)$

Fam = número de familias de mãe

Posição obtida na população da EMBRAPA

... QTLs significativos a $5 \%$ no...

(incluir no item 1 ) LS= "score" de pernas

Na população estudada foram encontrados no cromossomo 2 os seguintes QTLs significativos à $5 \%$ no genoma para PV35, PV41, PV42 e peso de peito. Para o cromossomo 4 foram encontrados os QTLs PV35, peso de peito, peso ao nascer e \% de gordura abdominal, tambem à $5 \%$ no genoma para a analise de F2. Para a analise de meios-irmãos, somente foram encontrados QTLs sugestivos, tanto para o cromossomo 2 como para o cromossomo 4. 
Dados Internacionais de Catalogação na Publicação (CIP) DIVISÃO DE BIBLIOTECA E DOCUMENTAÇĀO - ESALQ/USP

\section{Baron, Erica Elias}

Identificação de QTLs nos cromossomos 2 e 4 que atuam em caracteristicas de desempenho e carcaça em aves Gallus gallus / Erica Elias Baron. - - Piracicaba. 2004

$96 \mathrm{p}$.

Tese (doutorado) - Escola Superior de Agricultura Luiz de Queiroz, 2004

Bibliografia.

1. Carcaça 2. Cromossomo 3. Galinha 4. Genoma 5. Mapeamento genético 6. Marcador molecular I. Titulo

CDD 636.50824

"Permitida a cópia total ou parcial deste documento, desde que citada a fonte $-\Theta$ autor" 
Aos meus familiares

E amigos

\section{DEDICO}

Àqueles que participaram diretamente

nas atividades realizadas e possibilitaram

que esta fosse realizada

OFEREÇO 


\section{AGRADECIMENTOS}

- Ao Prof. Dr. Luiz L. Coutinho pela orientação técnica, disponibilidade e auxílio que me ajudaram na realização deste trabalho, bem como pela amizade nesses anos de convivência.

- Aos professores do Departamento de Zootecnia e Departamento de Genética pelas instruções técnicas necessárias à realização desta tese.

- Aos amigos de laboratório pela amizade e ajuda quando esta foi necessária.

- À Prof. Dra. Ana Silvia Moura pela disponibilidade e ajuda na redação desta tese.

- Às secretárias do Departamento de Zootecnia pela disponibilidade e atenção.

- À ESALQ/USP pela oportunidade da realização deste doutoramento.

- À EMBRAPA, Centro Nacional de Pesquisa em Suínos e Aves pela extensa colaboração, principalmente a Dra. Monica C. Ledur.

- Agradeço aos meus pais que continuam me apoiando nos meus projetos profissionais e pessoais.

- Agradeço aos meus familiares, sempre presentes inclusive nas horas difǐceis.

- Agradeço aos amigos pelo estímulo e a mizade.

- E a todos que de forma direta ou indireta contribuíram de maneira relevante para a elaboração deste trabalho.

- À FAPESP pela concessão da bolsa de estudos e reserva técnica. 


\section{SUMÁRIO}

Página

LISTA DE FIGURAS.......................................................................... viii

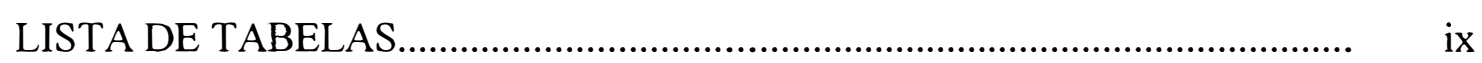

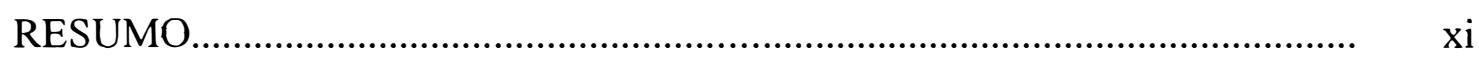

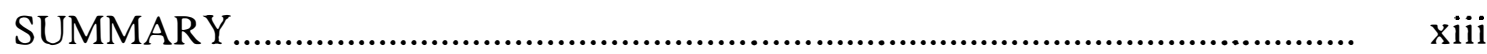

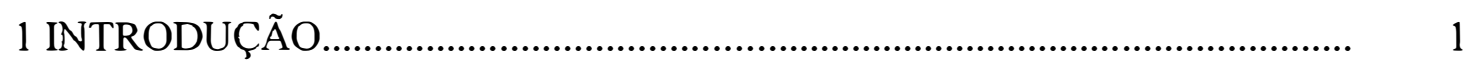

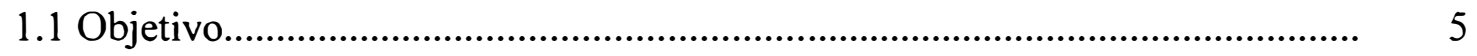

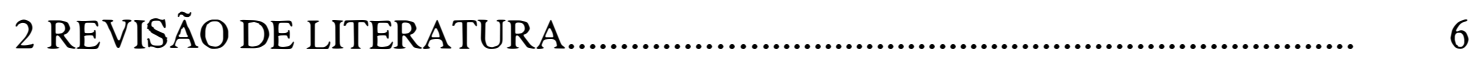

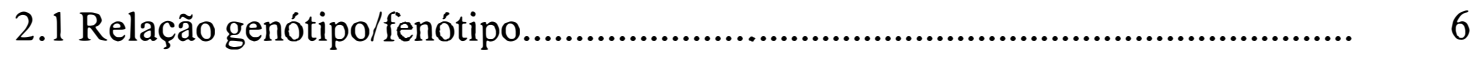

2.2 Mapeamento de QTLs por marcadores moleculares microssatélites.............. 7

2.2.1 Marcadores moleculares................................................................. 7

2.2.2 PIC e Heterozigosidade.................................................................... 10

2.3 Desequilíbrio de ligação e delineamentos populacionais............................ 11

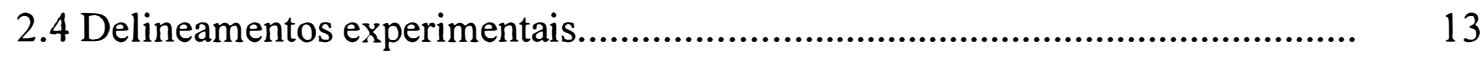

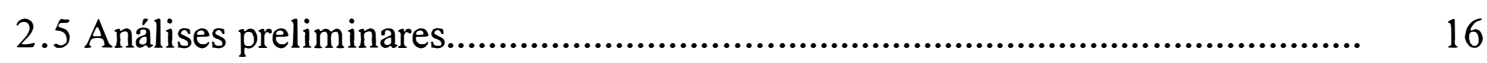

2.6 Métodos estatísticos....................................................................... 19

2.6.1 Análise de variância usando marcas simples........................................... 19

2.6.2 Métodos de regressão e mapeamento por intervalo.................................. 20

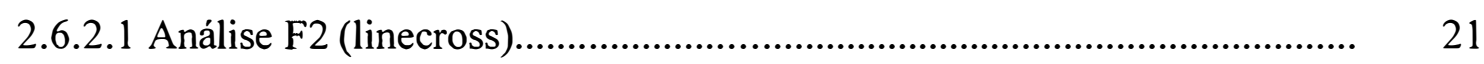

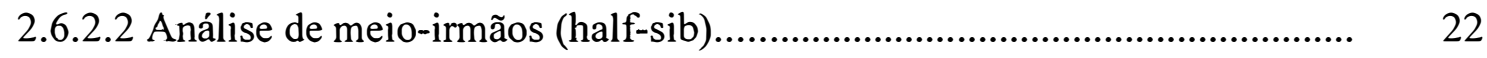

2.6.2.3 Modelos mistos............................................................................ 23

2.7 Resultados de mapeamento de QTLs em Gallus gallus.......................... 23 


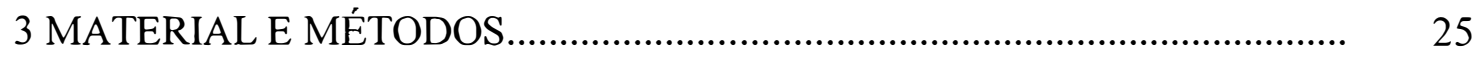

3.1 População Experimental............................................................................. 25

3.2 Colheita de dados fenotípicos..................................................................... 26

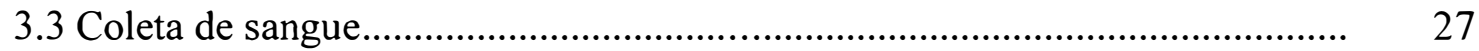

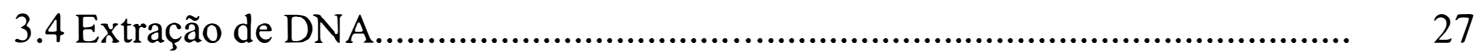

3.5 Leitura em Espectrofotômetro......................................................................... 29

3.6 Escolha dos 53 microssatélites dos cromossomos 2 e 4.................................. 29

3.7 Eletroforese em sequenciador automátic o ABI377 e genotipagem inicial do animais

3.8 Genotipagem seletiva - Escolha dos indivíduos F2 ...................................... 33

3.9 Montagem das placas para amplificação e corrida no sequenciador............... 34

3.10 Genotipagem seletiva - Amplificação pela PCR para os marcadores microssatélites infromativos dos cromossomos 2 e 4 .................................... 35

3.11 Eletroforese dos produtos da PCR ........................................................... 37

3.12 Precipitação dos produtos da PCR.............................................................. 37

3.13 Eletroforese em sequenciador automático MegaBACE e genotipagem seletiva dos animais............................................................................. 38

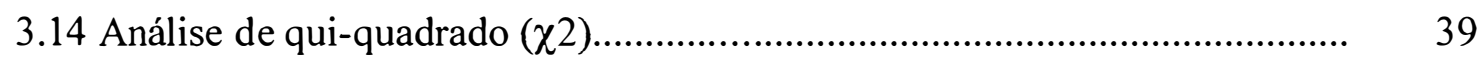

3.15 Determinação de PIC e heterozigosidade.................................................... 40

3.16 Genotipagem das famílias completas para os marcadores significativos no teste de qui-quadrado........................................................................... 40

3.17 Construção do mapa de ligação.................................................................... 41

3.18 Análise dos dados fenotípicos........................................................................ 43

3.19 Mapeamento de QTLs............................................................................... 43

4 RESULTADOS E DISCUSSÃO.................................................................. 48

4.1 Extração de DNA dos indivíduos F2 ............................................................ 48

4.2 Amplificação pela PCR..................................................................................... 49

4.3 Análise de dados fenotípicos - correlações fenotípicas e genéticas................. 51

4.4 PIC e heterozigosidade..................................................................................... 52 


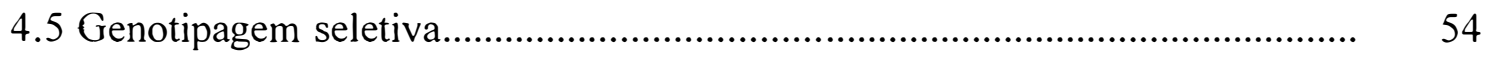

4.6 Escolha de marcadores informativos e genotipagem completa...................... 59

4.7 Construção do mapa de ligação......................................................................... 61

4.8 Análise de QTLs......................................................................................... 62

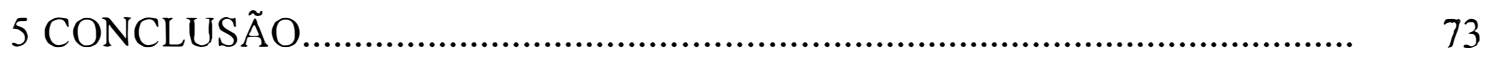

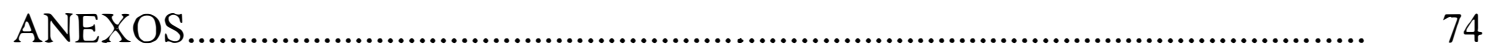

REFERÊNCIAS BIBLIOGRÁFICAS......................................................... 85 


\section{LISTA DE FIGURAS}

Página

1 Esquema do delineamento de família de filhas ou F2 utilizado........................ 26

2 Marcadores microssatélites testados na genotipagem seletiva para o cromossomo 2

3 Marcadores microssatélites testados na genotipagem seletiva para o cromossomo 4

4 Mapa dos marcadores e QTLs encontrados no cromossomo 2

5 Mapa dos marcadores e QTLs encontrados no cromossomo 4.

6 Curvas de mapeamento de QTLs para o cromossomo 2................................. 71

7 Curvas do mapeamento de QTLs para o cromossomo 4.................................. 72 


\section{LISTA DE TABELAS}

Página

1 Possíveis genótipos recombinantes para um marcador e QTL com dois alelos....

2 Marcadores microssatélites para o cromossomo 2 com suas respectivas posições em $\mathrm{cM}$, tamanho em pares de bases, marcação fluorescente e número de alelos

3 Marcadores microssatélites para o cromossomo 4 com suas respectivas posições em $\mathrm{cM}$, tamanho em pares de bases, marcação fluorescente e número de alelos.

4 Condições da reação de PCR ................................................................................. 36

5 Resultados obtidos na extração de DNA utilizando DNAzol................................ 49

6 Análise de correlação das carcaterísticas fenotípicas mensuradas na população..

7 Valores de PIC e heterozigosidade dos marcadores microssatélites dos cromossomos 2 e 4 .

8 Resultado da análise de qui-quadrado $(\chi 2)$ após genotipagem seletiva para os marcadores do cromossomo 2

9 Resultado da análise de qui-quadrado $(\chi 2)$ para os marcadores microssatélites do cromossomo 4 .

10 Categoria criadas por Hillel (1997).

11 Marcadores utilizados para a construção do mapa de ligação, famílias empregadas, e número de aves F2 genotipadas por marcador para o cromossomo 2 
12 Marcadores utilizados para a construção do mapa de ligação, famílias empregadas, e número de aves F2 genotipadas por marcador para o

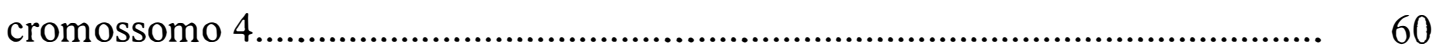

13 Mapa de ligação para os marcadores do cromossomo 2....................................... 61

14 Mapa de ligação para os marcadores do cromossomo 4....................................... 62

15 Localização e caracterização dos QTLs afetando características de desempenho e carcaça que tiveram ligação sugestiva na análise de "line cross" para os cromossomos 2 e 4 ............................................................................ 63

16 Localização e caracterização dos QTLs afetando características de desempenho e carcaça que tiveram ligação sugestiva na análise de "half-sib" para os cromossomos 2 e 4 


\title{
IDENTIFICAÇÃO DE QTLS NOS CROMOSSOMOS 2 E 4 QUE CONTROLAM CARACTERÍSTICAS DE DESEMPENHO E CARCAÇA EM AVES (Gallus gallus)
}

\author{
Autora: ERICA ELIAS BARON \\ Orientador: Prof. Dr. LUIZ LEHMANN COUTINHO
}

\section{RESUMO}

As avaliações genéticas, dos programas de melhoramento, utilizadas para seleção de animais para uma característica de interesse são comumente baseadas em observações fenotípicas. O interesse no desenvolvimento de técnicas que permitam a identificação de genes é encontrar meios mais eficientes de selecionar uma característica, normalmente de interesse comercial, influenciadas por um grande número de loci com pequeno efeito (teoria poligênica). Esses loci são denominados QTL (quantitative trait loci - loco de característica quantitiva). Com o uso de marcadores microssatélites, foram identificados QTLs para características de desempenho e carcaça, nos cromossomos 2 e 4 de aves. Partindo de uma população (F0) com base genética diferente, onde uma linhagem denominada TT foi selecionada para corte e outra, denominada CC, foi selecionada para postura, foram produzidas as gerações F1 (TC - macho TT acasalado com fêmea de postura). $\mathrm{O}$ acasalamento entre indivíduos $\mathrm{F} 1$ não aparentados produziu a geração $F 2$, e o desequilírio de ligação necessário para o mapeamento de QTL. Foi escolhida a estratégia de genotipagem seletiva nas primeiras genotipagens. Essa escolha permitiu que fossem determinadas regiões nos cromossomos 2 e 4 , com probabilidade de ter um 
QTL, uma vez os marcadores foram significativos a $10 \%$ na análise de qui-quadrado. A partir da seleção dos marcadores informativos, analisados na genotipagem seletiva, foram escolhidas as melhores famílias para serem genotipadas, separadamente nos cromossomos 2 e 4. À essas regiões de interesse nos cromossomos, foram incluídos um número maior de marcadores microssatélites como forma de aumentar a densidade de marcadores naquela região. Para os marcadores da genotipagem seletiva e os demais incluídos, foram genotipadas todas as progênies das famílias escolhidas, que em média eram de 100 indivíduos F2. O mapa de ligação do total de marcadores foi realizado com a utilização do programa CRI-MAP. Os dados fenotípicos foram pré-ajustados para os efeitos não-genéticos que foram signifitcativos para cada característica na análise de variância. A análise de mapeamento de QTLs foi feita por intervalo, usando método de regressão, onde é pré-suposto que as linhagens fundadoras são fixadas para os alelos alternativos do QTL. Essa análise é denominada "line cross". Uma análise complementar denominada "half-sib" foi realizada para analisar o efeito de substituição de alelos. As análises de "line cross" possuem maior poder de deteç̧ão de diferenças fenotípicas entre as linhagens fundadoras ou iniciais (F0) e as "half-sib" para as diferenças existentes dentro das linhagens. Foram encontrados para o cromossomo 2 sob análise de "linecross" 10 QTLs com, pelo menos, ligação sugestiva, e 11 para o cromossomo 4. Sob análise "half-sib" foram identificados 3 e 5 QTLs para os cromossomos 2 e 4 respectivamente. Os resultados dos mapas de ligação são consistentes com os publicados em outras espécies. Os resultados de mapeamento de QTLs utilizando a estratégia de genotipagem seletiva fortalecem a pré-suposição do poder de deteção maior esperado pela análise de "linecross", em relação à análise de "half-sib". 


\title{
IDENTIFICATION OF QTLS IN CHICKEN CHROMOSOMOES 2 AND 4 FOR GROWTH AND CARCASS TRAITS
}

(Gallus gallus)

\author{
Author: ERICA ELIAS BARON \\ Adviser: Prof. Dr. LUIZ LEHMANN COUTINHO
}

\section{SUMMARY}

The goal of animal breeding is to achieve genetic progress. Until recently animals were selected after genetic evaluations based on phenotypic data. Finding new or more efficient ways to select for desirable traits is the most important reason for the interest in developing methods to find genes. Animal breeders are mostly interested in economic traits, which have a quantitative nature. These traits are usually influenced by a number of loci which are named quantitative trait loci or QTLs. The objective of the thesis was to identify QTLs on chromosomes 2 and 4 that affect growth and carcass traits. Two chicken lines, one broiler (TT) and another layer (CC), were used to produced and F2 population. Selective genotyping was used to identify regions containing potential QTL. The selected regions were then typed in all individuals of the most informative families. A total of 614 individual from 06 full-sib families were genotyped. The linkage map were constructed using the CRI-MAP program. Phenotypic data were adjusted to significative non-genetic effects in ANOVA analysis. A interval mapping method were used to map QTLs, under linecross and half-sib analysis. Under the linecross model it is assumed that two lines, although they may segregate at the 
marker loci, are fixed for alternative alleles the QTL affecting the traits of interest. Ten QTLs were found in chromosome 2 with, at least, suggestive linkage under linecross analysis. In chromosome 4, eleven QTLs were found under this same analysis. Under half-sib analysis, 3 and 5 QTLs were identified in chromosomes 2 and 4, respectively. These results support the use of selective genotyping strategy to map QTL and the assumption of linecross analyses are more powerful than half-sib analyses to our population structure. 


\section{INTRODUÇÃO}

O objetivo do melhoramento genético animal é obter progresso genético numa determinada população. Assim, num programa de melhoramento são selecionados aqueles animais que contribuem de forma significativa para uma característica de interesse, com o uso de avaliações genéticas. A seleção genética para um avanço nos processos econômico e produtivo de animais tem obtido sucesso nos últimos 50 anos (Havestein et al., 1994).Inicialmente essas avaliações eram baseadas exclusivamente em observações fenotípicas.

Uma das razões que podemos citar para o interesse na genômica e no desenvolvimento de técnicas que permitam a identificação de genes é encontrar novos ou mais eficientes meios de selecionar uma característica de interesse ou contra uma característica indesejável.

O ganho de peso e o rendimento de carcaça em aves são importantes características fenotípicas para a indústria de frangos de corte. No mercado nacional (Empresa Brasileira de Pesquisa Agropecuária - EMBRAPA, 2004) os principais indicadores da produção avícola apontam um aumento na exportação de carne de frango de $15,5 \%$ e $18,6 \%$ em 2000 e 2001 respectivamente, para $21,4 \%$ em 2003, por exemplo. Esse crescimento se reflete inclusive na demanda interna que chega a atingir 33,7 $\mathrm{kg} / \mathrm{hab} / \mathrm{ano}$. No comércio internacional de carne de frango, permanece o Brasil como segundo no ranking de exportação com 1,625 milhões de toneladas em 2002, sendo que as projeções de crescimento do mercado a médio prazo são de $40 \%$ na quantidade exportada de cortes e $17 \%$ ao ano de carcaças inteiras. 
Para o setor avícola brasileiro é assim, extremamente importante perceber as especificidades atuais e potenciais dos consumidores, desenvolvendo tecnologias que atendam às suas novas exigências. Tal capacitação poderá alavancar não somente o mercado externo como o interno, onde se percebem novos hábitos e valores do consumidor brasileiro. (EMBRAPA, 2004).

No últimos 15 anos técnicas têm sido desenvolvidas, capacitando a detecção de genes e de marcadores genéticos. Esses marcadores genéticos são pequenos segmentos de DNA que possibilitam o estudo de segregação alélica de uma geração à outra.

Vários tipos de marcadores têm sido estudados tanto para o seu uso na seleção assistida por marcadores (MAS) onde as características fenotípicas de interesse comercial são acompanhadas por marcadores, ou seja, o princípio básico é que a seleção para caracteres com fácil identificação fenotípica possam simplesmente ser identificados por marcadores de interesse ligados àquela característica (Arus et al.; 1993); como na construção de mapas genéticos, pois podem ser usados para identificação e localização de loci com maiores efeitos associados à características quantitativas economicamente importantes (QTL), com vantagens e desvantagens.

Entre os diferentes tipos de marcadores até hoje estudados no genoma de aves, os do tipo microssatélites têm sido mais utilizados. Os marcadores microssatélites têm geralmente maior heterozigosidade que os RFLPs, sendo seus resultados mais facilmente interpretados; aém disso são distribuídos aleatóriamente ao longo do genoma (Groenen et al., 2000). O polimorfismo dos microssatélites ocorre devido à diferenças no número de vezes que uma seqüência se repete. Tendo de 100 a 300 nucleotídeos "de comprimento", eles podem ser amplificados pela PCR. Muitos microssatélites têm sido descritos no genoma de aves, (Bumstead \& Palyga, 1992; Cheng \& Crittenden, 1994; Crooijmans et al., 1993; Crooijmans et al., 1994; Groenen et al., 1998; Groenen et al., 2000) e por serem altamente polimórficos, têm sido propostos como marcadores para mapeamento de QTLs em diferentes populações inclusive aves, embora sejam menos frequentes e menores quando comparados aos de mamíferos (Cheng, 1997; Groenen et al., 2000). 
A utilização da informação dos marcadores genéticos requer métodos estatísticos para a reconstrução do genoma e o estudo da relação da segregação de segmentos do cromossomo com o fenótipo. Para a localização de um marcador genético é necessária a construção de um mapa de ligação com outros marcadores. Deste modo a utilização do mapa auxiliará na localização do gene.

No entanto, como dito anteriormente nosso interesse é avaliar características que tenham importância econômica e não um gene aleatório. Essas características são geralmente de natureza quantitativa e influenciadas por um grande número de loci com pequeno efeito (teoria poligênica). No entanto em situações em que um ou poucos pares de genes com um efeito maior ("major gene") sobre o fenótipo, o modelo de herança poligênica não resulta na mesma eficiência. Esses loci são denominados QTL (quantitative trait loci - loco de característica quantitiva), apesar de existir na literatura alguma divergência em relação à QTL e "major gene". Neste caso, segundo Falconer \& Mackay (1996), "maior efeito" não significa necessariamente, um efeito de três desviospadrão em relação à média da população. Com a informação obtida neste tipo de estudo é possível a realização da avaliação genética com informações de parentes por exemplo, assim como a adição de novas informações conforme elas vão sendo coletadas. A velocidade na seleção também é aumentada um vez que é possível a coleta de informação de animais de qualquer idade (van Kaam et al., 2000).

O genoma da galinha consiste de 38 pares de cromossomos autossômicos e 2 sexuais $\mathrm{Z}$ e W. E podem ser divididos em três grupos: 5 pares de macrossomos, 5 intermediários e 29 microcromossomos (Cheng, 1997). Os primeiros mapas genéticos da galinha foram desenvolvidos há 80 anos atrás baseados em características morfológicas. A análise do genoma realizada com o auxílio de marcadores genéticos permite a análise da extensão de conservação do genoma, a ordem funcional dos genes, assim como o interesse evolucionário e as possíveis ligações com o genoma de outros vertebrados e o mapeamento de QTLs (Crittenden et al.; 1993).

A primeira população referência utilizada para a construção do primeiro mapa de ligação para Gallus foi a população referência Compton (C), que consiste de um backcross (BC) de duas linhagens parcialmente endogâmicas White Leghorn (linhas $\mathrm{N}$ e 
151). Estas linhas diferem na susceptibilidade à doenças, mas em particular, a linha $\mathrm{N}$ é resistente à salmonelose enquanto a linha 151 é altamente susceptível. Este mapa foi publicado por Bumstead \& Palyga (1992). Um segundo mapa foi publicado por Levin et al. (1993, 1994), com a população East Lansing (EL). Essa consiste de um retrocruzamento de uma linhagem parcialmente endogâmica Red Jungle Fowl (JF) com uma altamente endogâmica White Leghorn (Crittenden et al., 1993). Uma terceira população para mapeamento, chamada Wageningen resource population (WAU), foi desenvolvida por Groenen et al. (1998) a partir do cruzamento entre duas linhagens comerciais divergentes da Nutreco BV, onde os animais G1 (geração 1) não relacionados, foram cruzados para produzir 10 famílias de irmãos completos, com uma média de 46 progênies por família. A geração F0 consistia de duas linhagens maternas originadas da raça White Plymounth Rock.

As três populações estudadas apresentaram marcadores microssatélites em comum, mas também diferenças em relação à distância em cM (centiMorgam) entre os marcadores, número de alelos e conteúdo de informação de polimorfismo (PIC). Com os marcadores microssatélites em comum, fo i possível a construção de um mapa de ligação consenso, com um total de 1889 locos, cobrindo aproximadamente 3800 centiMorgans (cM) do genoma da galinha (Groenen et al., 2000).

Os diversos experimentos que têm sido realizados com populações de aves mostram que em uma mesma população nós podemos ter variações nas correlações das características, e nas localizações dos QTLs para características correlacionadas. Apesar dessas características de ganho de peso e rendimento de carcaça serem características em que até hoje se obteve um progresso genético por meio da seleção tradicional, o uso de seleção assistida por marcadores ou localização de genes que regulam essas características podem ser mais uma alternativa viável para o aumento da produção de frangos. 


\subsection{Objetivo}

Os objetivo deste estudo são i) construir um mapa de ligação para os cromossomos 2 e 4 a partir da genotipagem com marcadores microssatélites, ii) mapear QTLs, que estejam associados às características de desempenho e carcaça, na população desenvolvida na Embrapa Suínos e Aves. 


\section{REVISÃO DE LITERATURA}

\subsection{Relação genótipo/fenótipo}

O melhoramento é baseado no conhecimento dos parâmetros genéticos para uma característica de interesse, como por exemplo, herdabilidade, variância genética e correlações genéticas numa população. Esses parâmetros são geralmente estimados por análise estatística dos fenótipos dos indivíduos e de indivíduos aparentados. Entretanto essas informações não são suficientes para informar o número de genes que afeta uma característica, os efeitos de um ou dois genes isolados ou sua localização no genoma.

Muitas das características de interesse para produtores e geneticistas são de natureza quantitativa, ou seja, possuem escala contínua de valores, onde o fenótipo representa a soma dos efeitos genéticos e ambientais relacionados à população, bem como sua interação.

Os QTLs são identificados por associações estatísticas significativas entre os genótipos dos indivíduos e a variabilidade fenotípica na progênie segregante. A grande vantagem desse método é que temos hoje publicados um grande número de marcadores para aves, em especial Gallus gallus, que permitem a varredura do genoma completo do animal, e dessa forma a identificação da região que influencia a característica. A desvantagem é que a metodologia fornece apenas a posição no mapa genético, apesar de fornecer também o quanto explica da variação, o efeito aditivo e de dominância, necessitando de um posterior estudo para posicionamento no mapa físico seguido de um estudo de mapeamento comparativo para a identificação do(s) gene(s) que controla (m) a característica. 


\subsection{Mapeamento de QTL por marcadores moleculares microssatélites}

Vários estudos têm indicado que o conhecimento sobre marcadores genéticos ligados a genes que afetam características quantitativas podem aumentar a resposta à seleção de programas de melhoramento animal, utilizando como ferramenta a seleção assistida por marcadores (MAS), especialmente para características de difǐcil mensuração em programas de melhoramento convencionais (Muir, 1996).

Para se detectar QTLs é necessária a existência de desequilíbrio de ligação entre os alelos do loco marcador e do QTL para a característica em estudo. Desta forma, precisamos de duas populações que tenham diferentes alelos, que afetam a característica estudada, fixados; e marcadores microssatélites polimórficos para essas duas populações. Essas duas populações são então acasaladas para gerar uma população F1 a qual é aleatóriamente cruzada para gerar uma população F2 ou uma população de retrocruzamento. Os fenótipos e os genótipos dessa população F2 é determinados e o mapeamento de QTL se dá analisando os marcadores ao longo do genoma, classificando os indivíduos em classes genotípicas e realizando um teste estatístico para verificar se existe diferença significativa no fenótipo dos indivíduos das diferentes classes.

\subsubsection{Marcadores Moleculares}

Por marcador molecular define-se todo e qualquer fenótipo molecular oriundo de um segmento específico de DNA, correspondente a regiões expressas ou não do genoma (Ferreira \& Grattapaglia, 1996).

Os marcadores moleculares podem ser divididos em dois grupos: os do tipo I e do tipo II. Os do tipo I são aqueles que estão inseridos ou adjacentes a genes conhecidos; e os do tipo II são os marcadores compostos de fragmentos de DNA aleatórios (O'Brien \& Graves, 1991, citado por Crooijmans, 2000).

Os mais representativos são os RFLPs ("restriction fragment lenght polymorphisms"), minissatélites, microssatélites, RAPDs ("random amplified 
polymorphic DNA"), AFLPs ("amplified fragment lenght polymorphism"), SSCPs ("single strand conformational polymorphism"), ASOs ("allele specific oligo") e SNPs ("single nucleotide polymorphism").

Os RFLPs foram primeiramente utilizados por Botstein et al. (1980), e como o próprio nome já diz seu polimorfismo é baseado em variações na sequência de DNA de sítios de enzimas de restrição, criando diferentes tamanhos de fragmentos. Esse marcador tem a vantagem de cobrir todo o genoma e possuir expressão co-dominante. Foi primeiramente utilizado com sondas de hibridização pelo processo de "Southern Blot", que tinha como limitação a não existência de uma biblioteca de sondas disponível ao se iniciar um projeto. No entanto, com a PCR foi possível sua adaptação, e uma vez conhecida a região de interesse, um vasto número de enzimas de restrição podem ser utilizadas. Mesmo assim, há uma redução do polimorfismo genético já que apenas a região coberta pela sonda é amplificada (Ferreira \& Grattapaglia, 1996). O primeiro mapa de ligação do genoma de aves foi baseado em polimorfismos desse marcador, publicado por Bumstead \& Palyga (1992).

Os RAPDs são baseados no uso de primers aleatórios, de em média 10 pares de bases. O resultado é um grande número de segmentos de DNA de diferentes tamanhos que podem dificultar a análise do resultado. Seu polimorfismo se dá pela ausência ou presença de um ou mais fragmentos e sua desvantagem é de ter expressão dominante, ou seja, não é possível visualizar os indivíduos heterozigotos (Ferreira \& Grattapaglia, 1996).

AFLPs são considerados como uma técnica de "fingerprint" e seu polimorfismo está baseado numa pré-seleção de fragmentos de restrição. Em aves já foram descritos 552 AFLPs, no entanto, como somente dois alelos são detectados e é um marcador multilocus, não estando clara se sua expressão é dominante ou co-dominante, AFLPs não são muito utilizados em mapeamento de populações "outbred" pequenas (Crooijmans, 2000).

Os marcadores baseados em polimorfismo de conformação da fita simples (SSCPs) são aqueles onde a diferença de mobilidade da fita simples de DNA em 
eletroforese com gel não desnaturante é que determina a variabilidade (Crooijmans, 2000).

Foram mapeados no genoma da galinha 71 marcadores baseados na amplificação de partes específicas de genes (ASOs) (Crooijmans, 2000). Primeiramente os parentais da população tem seus DNAs sequenciados à procura da ocorrência de substituições de base. Encontrado um polimorfismo, a PCR é feita de forma a identificar um alelo específico (Ferreira \& Grattapaglia, 1996).

Um outro tipo de marcador tem sido bastante estudado. Os SNPs têm seu polimorfismo baseado na mudança de um único nucleotídeo na sequência de DNA. Em aves a ocorrência de SNPs é de 1 para 100 pares de bases (pb) segundo Vignal et al. (2000).

Os marcadores minissatélites e microssatélites são caracterizados por seqüências repetidas dispersas pelo genoma. O polimorfismo desse tipo de marcador se dá pelo número de repetições em cada alelo. A diferença entre eles é que os minissatélites são sequências repetidas de 20 a 60 pb e em frangos não são distribuídos aleatoriamente, sendo que vários grupos de ligação consistem de marcadores minissatélites (Groenen et al., 2000). Os microssatélites são repetições de um mono, di ou trinucleotídeo, localizado dentro de regiões de seqüência única no genoma (Tautz, 1989). Em genomas de aves, estas seqüências são mais freqüentes, melhor distribuídas ao acaso e formam locos genéticos muito mais polimórficos que os minissatélites. Estes marcadores geralmente apresentam uma heterozigose superior à fornecida por RFLPs, sendo de interpretação muito mais fácil do que os padrões gerados por minissatélites multilocais. As vantagens associadas aos microssatélites são codominância e facilidade de serem obtidos por reação em cadeia da polimerase (PCR), o que torna possível a padronização dos protocolos entre laboratórios. Outras vantagens são sua distribuição aleatória, facilidade de serem isolados e alta porcentagem dos isolados serem polimórficos. Por essas razões muitos microssatélites têm sido isolados no genoma da galinha, num total de mais de 800 marcadores microssatélites polimórficos (Groenen et al., 2000).

O mapeamento de QTLs por regiões microssatélites loco específico supera muitas das dificuldades associadas a outros tipos de marcadores. Esses marcadores 
geralmente apresentam uma heterozigose superior à fornecida por RFLPs, sendo de interpretação muito mais fácil do que os padrões gerados por minissatélites multilocais.

\subsubsection{PIC e Heterozigosidade}

O uso de marcadores genéticos para mapeamento de QTL é uma nova ferramenta principalmente para os estudos em animais, no entanto o impacto em manejo de aves é relativamente recente e seu uso tem sido aplicado tanto em estudos dentro de determinadas raças como em cruzamentos industriais (Dodgson et al., 1997).

Uma das mais importantes características de um locus é sua heterozigosidade. Esta é definida como a probabilidade de um indivíduo ser heterozigoto para um locus na população. Normalmente seus estimadores são baseados em frequências alélicas. Um marcador que possui heterozigosidade igual ou maior a $70 \%$ é considerado altamente polimórfico (Liu, 1998).

O estudo de QTL vem abrangendo características que afetam o crescimento (Groenen et al., 1997; Van Kaam et al., 1999 a), conversão alimentar (Van Kaam et al., 1999 a), características de carcaça (Van Kaam et al., 1999 b), resistência à salmonelose (Hu et al., 1997) e doença de marek (Vallejo et al., 1998). Há algumas desvantagens em se estudar animais que são de populações resultantes de longos períodos de seleção, porque os loci para as características estudadas ou estão fixados ou em frequências extremas na população, o que reduz o conteúdo de informação dos marcadores e do QTL. Além disso, há outros fatores que afetam o poder de detecção dos QTLs, como número e localização genômica dos genes que afetam a característica, a distribuição dos efeitos dos genes e suas interações, e sua herdabilidade. Também há fatores associados à metodologia como a densidade de marcadores por cromossomo, tipo de população estudada e tamanho da amostragem, número de famílias e tamanho das famílias estudadas, por exemplo, uma família grande com tamanho amostral grande tem maior poder de detectar um QTL com efeito genético menor do que uma família de tamanho pequeno (Lander e Botstein, 1989). Assim aumentando o tamanho das famílias estudadas melhoramos o poder do teste mais do que aumentando o número de famílias 
estudadas. É sabido que o conteúdo de informação de polimorfismo (PIC) é a probabilidade de um dos pais ser heterozigoto para um locus marcador e o outro ter um genótipo diferente (Botstein et al., 1980), e dessa forma seria uma forma eficiente de determinar o número de famílias e tamanho das famílias para experimentos com QTL. Em adição, as famílias poderiam ser escolhidas baseadas na heterozigosidade dos pais de forma a aumentar a informação obtida dos marcadores.

\subsection{Desequilíbrio de ligação e delineamentos populacionais}

Ligação gênica é definida como a associação entre genes localizados num mesmo cromossomo, sendo que para esses genes, as proporções genotípicas esperadas após um determinado cruzamento se afastam das proporções Mendelianas (esperadas caso a segregação fosse independente), isto é, tendem a ser herdados juntos, indicando a existência de associação entre os dois loci estudados. (Liu, 1998). Diferentes tipos de cruzamentos são realizados entre linhagens altamente divergentes para conseguir-se o desequilíbrio de ligação em populações não-endogâmicas (Lynch \& Walsh, 1998), uma vez que a probabilidade de detectar QTLs depende do montante de desequilíbrio de ligação entre o marcador e o QTL. Segundo Yonash et al. (2001) associações entre marcadores e a característica de interesse podem ser estudadas pela comparação do desempenho produtivo dos indivíduos de um delineamento F2 ou retrocruzamento com diferentes genótipos.

Deste modo, vamos considerar um cruzamento entre duas populações endogâmicas ou raças puras (inbred) que possuem os marcadores M1 e M2, os quais estão ligados aos alelos do QTL Q1 e Q2. A população endogâmica l é homozigota para os alelos M1 e Q1 enquanto que a linha 2 é homozigota para os alelos M2 e Q2. Essas populações são cruzadas para obtenção da população F1. A partir desses indivíduos os dois delineamentos experimentais citados acima podem ser utilizados para detectar QTLs, o F2 ou o retrocruzamento (backcross).

No delineamento de retrocruzamento os indivíduos Fl são cruzados com uma das linhas ou raças puras. Considerando que esses indivíduos sejam retrocruzados com a 
linha 1, todos os indivíduos F1 são duplos heterozigotos, podendo produzir 4 tipos de gametas M1Q1, M1Q2, M2Q1 e M2Q2. Os gametas parentais são nesse exemplo, M1Q1 e M2Q2. Durante a meiose as cromátides homológas sofrem um processo de quebra e reunião, e se no processo de reunião ocorrer troca de partes de cromossomos entre cromátides não-irmãs, ocorre o fenômeno chamado crossing over. $\mathrm{O}$ resultado dessa recombinação é o aparecimento de cromossomos não parentais, ou recombinantes, a determinada freqüência, chamada freqüência ou taxa de recombinação (Weller, 2001). Assim, por recombinação meiótica serão geradas combinações gaméticas que não estão presentes em nenhuma das linhagens parentais, sendo chamadas essas novas combinações de recombinantes. A diferença esperada no valor fenotípico das progênies depende da fração de recombinação entre $\mathrm{M}$ e $\mathrm{Q}$, do efeito aditivo do gene (a) e do efeito de dominância desse QTL.

No delineamento experimental ou modelo genético chamado de F2, os indivíduos F1 são cruzados aleatoriamente para a formação de indivíduos F2. Nessa população podem ser distinguidos 3 genótipos, M1M1, M1M2 e M2M2, e a diferença esperada entre os indivíduos M1M1 e M2M2 se deve ao efeito aditivo (a). Informação sobre o efeito de dominância nesse caso é obtido pela informação dos indivíduos F2 M1M2.

Em populações não endogâmicas também chamadas de "outbreds", o desequílibrio de ligação pode ser encontrado dentro de famílias, isso devido à cosegregação do marcador e do QTL, já que elas não estão fixadas para alelos do QTL.

A idéia é traçar a segregação dos pais para as progênies e determinar dentre os indivíduos $\mathrm{F} 2$, se os que receberam alelos para o marcador do pai diferem da média com respeito à característica analisada. Quando consideramos uma população com dois alelos para o marcador e dois alelos para o QTL, podemos diferenciar 10 diferentes recombinantes, como pode ser visto na Tabela 1 (Weller, 2001): 
Tabela 1. Possíveis genótipos recombinantes para um marcador e QTL com dois alelos

\begin{tabular}{cccc}
\hline $\begin{array}{c}\text { Genótipo do } \\
\text { marcador }\end{array}$ & \multicolumn{3}{c}{ Genótipo do QTL* } \\
\hline & Q1Q1 & Q1Q2 & Q2Q2 \\
M1M1 & M1Q1/M1Q1 & M1Q1/M1Q2 & M1Q2/M1Q2 \\
M1M2 & M1Q1/M2Q1 & M1Q1/M2Q2 & M1Q2/M2Q2 \\
& & M1Q2/M2Q1 & \\
M2M2 & M2Q1/M2Q1 & M1Q1/M1Q1 & M2Q2/M2Q2 \\
\hline
\end{tabular}

* Recombinantes que são informativos para a detecção de QTLs em negrito.

Apesar dos vários recombinantes, somente dois são informativos para a detecção de QTL, como pode ser observado também na Tabela 1. Para os dois genótipos observados, pode-se traçar a origem deles e uma diferença é esperada se o QTL estiver ligado ao marcador. Essa diferença é devida à fração de recombinação entre $\mathrm{Me} \mathrm{Q}$; a um efeito aditivo (a) e efeito de dominância (d). Aqui a diferença esperada também depende da frequência alélica de Q1 (p) e Q2 (q) na população (Lynch \& Walsh, 1998).

Quando a ocorrência de determinado marcador é independente da segregação dos alelos do QTL, não é possível sua determinação, e isso acontece quando a população está em equilíbrio de ligação (Falconer \& Mackay, 1996). Dessa forma se utilizam em estudos de mapeamento cruzamentos controlados, chamados de delineamentos genéticos, que visam maximizar o desequilíbrio de ligação.

\subsection{Delineamentos Experimentais}

Em linhagens que não são completamente endogâmcias, como espécies animais, frutas e árvores em reservas florestais, a ligação genética entre QTL e marcador é incompleta, ou seja, a taxa de recombinação é diferente de zero, as estimativas dos efeitos do QTL poderá ser viesada pela taxa de recombinação, reduzindo-se o poder para se detectar a ligação (Weller, 2001). Dessa maneira é necessário utilizar delineamentos 
experimentais para aumentar o poder de detecção de QTLs, assim como minimizar custos derivados da experimentação.

Três diferentes desenhos podem ser distinguidos, cruzamento entre linhagens divergentes; análise dentro de famílias onde as famílias podem ser de irmãos completos ou meio-irmãos e análise de pedigree completo onde são exploradas todas as relações de parentesco dentro da população. Weller et al. (1990) analisou o poder de deteç̧ão de QTLs com duas ou três gerações nos delineamentos de meio-irmãos (half-sib) para populações não endogâmicas (outbreds) de gado leiteiro. Foi verificado pelos autores a influência na deteç̧ão pelo tamanho do efeito do QTL, herdabilidade da característica, tamanho de família e número de família de meios-irmãos. Van der Beek et al. (1995) trabalhando com aves, com delineamentos de duas e três gerações, avaliou o poder de deteç̧ão em experimentos com estrutura de irmãos completos. Num delineamento de meio-irmãos os genótipos dos marcadores foram obtidos para o pai e as progênies, mas não é considerado o cruzamento. No delineamento de irmãos completos os genótipos dos marcadores foram obtidos para ambos os pais e progênies. No delinemento de duas gerações os fenótipos foram obtidos das progênies. Para a obtenção dos resultados foi considerado neste experimento, um QTL que explica $1 \%$ da variância fenotípica, que tem uma heterozigosidade de $50 \%$ e está localizado no meio de um intervalo de $20 \mathrm{cM}$, flanqueado por dois marcadores informativos. Os autores, Weller et al. (1990) como Van der Beek et al. (1995), puderam verificar que o aumento do número de filhas por macho é mais eficiente para a melhoria do poder de teste, do que o aumento do número de famílias, além de exigir menor número de animais genotipados.

Muranty (1996) também estudou o poder de deteç̧ão de QTLs usando famílias de irmãos completos, com os dois tipos de estratégias para populações "outbred": F2 e o back-cross (BC). Uma das conclusões do autor é que marcadores microssatélites multialélicos têm maior poder de detecção do que marcadores bialélicos em populações segregantes "outbred". No entanto o poder aumenta quando além de usar marcadores multialélicos, os parentais utilizados nos cruzamentos são potencialmente heterozigotos para o QTL. Haley et al. (1994), mostraram que em populações "outbred" com o método de marcadores flanqueando o intervalo podem parcialmente melhorar a perda de poder 
por causa dos marcadores serem parcialmente informativos. Muranty (1996) ainda conclui sobre os delineamentos F2 e BC que o nível de poder obtido foi similar considerando as condições ótimas de PIC e heterozigosidade que foram consideradas na simulação, exceto quando o poder atinge o limite nos casos de marcadores bialélicos. Um outro resultado deste estudo é que um dos parâmetros determinantes do poder de detecção é o número de parentais na população e não o número de famílias, entretanto o nível do poder aumenta quando aumentam também o número de parentais.

Ainda segundo Weller et al. (1990) em delineamentos F2 com irmãos-completos cada indivíduo é usado para a estimação de dois contrastes, aqueles entre os alelos da mãe e entre os alelos do pai. Haley \& Knott (1992) também mostraram que o uso de marcadores completamente informativos pode aumentar substancialmente o poder de detecção de QTLs.

Assim em vários estudos foi possível a localização de QTLs em populações obtidas de delineamentos F2 ou retrocruzamento utilizando como parentais linhagens divergentes (Soller et al., 1976; Weller et al., 1990; Lander \& Botstein, 1989; Beckmann \& Soller, 1988; Haley \& Knott, 1992; Zhu et al., 2001).

Todos estes estudos nos mostram que a variância explicada pelo QTL também é importante e depende da heterozigosidade do QTL. Na maioria das simulações foi assumida uma heterozigosidade para o QTL de 0,5 , que é máxima considerando que o QTL possui dois alelos, numa população em equilíbrio de ligação. Para uma heterozigosidade menor, mais famílias são necessárias para a obtenção do mesmo poder. A relação entre heterozigosidade no QTL e número de famílias é aproximadamente linear (Weller et al., 1990).

De qualquer modo, o melhor delineamento experimental para a formação das famílias que serão genotipadas dependerá da espécie a ser estudada, do valor econômico das linhagens que serão estudadas, do custo relativo das genotipagens, do tipo de cruzamento que a espécie permite (autocruzamento ou não), da fecundidade relativa dos dois sexos, quantos indivíduos expressam a característica e em quais circunstâncias e a possiblidade de explorar a variância genética de dominância. Segundo Weller (2001), o delineamento F2 é o único delineamento que pode ser usado para estimar a dominância 
diretamente. Por meio das médias, ou valores esperados, das classes de marcadores, é possível verificar se o QTL está ligado ao marcador. Os contrastes passam a ser função de a ou d, possibilitando o cálculo desses parâmetros separadamente, sendo esta uma vantagem do delineamento $\mathrm{F} 2$ em relação ao retrocruzamento. $\mathrm{O}$ contraste entre homozigotos fornece o efeito aditivo e o contraste entre o heterozigoto e os dois homozigotos, o efeito de dominância.

\subsection{Análises Preliminares}

Estratégias de mapeamento foram elaboradas com o objetivo de obter o máximo de poder estatístico de detecção do QTL com o mínimo custo possível. Normalmente os custos das análises dos dados são baixos, sendo os custos da genotipagem dos indivíduos a parte mais onerosa dos experimentos de mapeamento.

Replicação de progênies (aplicadas somente à espécies vegetais cultivadas), genotipagem seletiva e "sample pooling" (SP) podem aumentar o poder de detecção por indivíduo genotipado. Essas três técnicas requerem um aumento no número de indivíduos fenotipados e são aplicadas quando os custos de fenotipagem são menores que os de genotipagem. Segundo Weller (2001), exceto a replicação de progênies, as demais estratégias são mais apropriadas para experimentos onde será analisado um pequeno número de características, ou que essas sejam correlacionadas.

Michelmore et al. (1991) propuseram que genes de maior efeito causadores de doenças poderiam ser identificados por "bulk segregant analysis". Nessa estratégia, grupos de indivíduos que possuíam um mesmo fenótipo tinham seus DNAs misturados e posteriormente os grupos para os diferentes fenótipos eram genotipados. Se houvesse uma diferença significativa na intensidade de uma banda, seria possível deduzir que o marcador está ligado a um gene afetando a característica de interesse. Essa metodologia tem sido chamada de "sample pooling" e pode ser aplicada para a detecção de QTL com as seguintes observações segundo Lipkin et al. (1998): deve ser possível determinar o número de indivíduos de cada genótipo em cada grupo; "sample pooling" deve ser usada junto com a genotipagem seletiva. Weller (2001) afirma que há perda de informação 
com o uso dessa técnica pelos dois seguintes fatores inexatidão na determinação da frequência alélica a partir da intensidade da bandas genotipadas e não identificação do específico valor fenotípico de cada indivíduo genotipado especificadamente.

Lebowitz et al. (1987) desenvolveram a estratégia de genotipagem seletiva (SG selective genotyping) que mais tarde foi melhorada por Lander \& Botstein (1989) e Darvasi \& Soller (1992). O raciocínio por trás do método é que numa população segregante, algumas progênies contribuem com maior informação de ligação que outras. Os primeiros, que possuem maior informação de ligação são aqueles onde pelos genótipos claramente pode-se inferir os fenótipos extremos.

A genotipagem seletiva também pode ser aplicada a populações nãoendogâmicas, contudo a seleção deve ser aplicada dentro de famílias segundo Bovenhuis \& Spelman, (2000) devido ao fato de nessas populações os marcadores e QTLs possivelmente não segregarem igualmente em todas as famílias. Muranty et al. (1997) afirmaram que o valor quantitativo de cada indivíduo é o resultado de um efeito de família, que pode ser separado em i) efeitos geral e de habilidade de combinação específica, ii) efeito de genótipo dentro de família e iii) efeito ambiental. Se os indivíduos forem escolhidos nos extremos da população, todos os indivíduos de algumas famílias poderiam ser escolhidos e nenhum indivíduo de algumas outras famílias poderiam ser escolhidos, justamente pelo efeito de família. Dessa forma nas populações não-endogâmicas os indivíduos devem ser escolhidos nos extremos dentro de cada família. Também Hillel (1997) afirma que a genotipagem seletiva é a escolha de indivíduos de maior ou menor valor, que pode ser realizada dentro de cada família F1. Da mesma maneira, Falconer \& Mackay (1996) afirmam que é melhor ter um maior número de famílias representadas do que poucas famílias com um grande número de indivíduos, pois quando temos um alelo de efeito principal representado poucas vezes até podemos detectar um QTL, porém quando temos um alelo de efeito menor se perdermos alguma família em que ele está presente podemos não detectar o QTL. No entanto, se ajustarmos para o efeito de machos e fêmeas F1 perdemos o efeito de família, podendo assim não detectar QTLs de efeito menor (falsos negativos). 
Segundo Weller (2001) se a quantidade de dados fenotípicos é grande, o poder por indivíduo genotipado pode ser aumentado pela genotipagem seletiva daqueles indivíduos com os maiores e os menores valores para a característica estudada. Segundo Liu (1998), este procedimento pode tendenciar os resultados dos testes de hipótese e a estimação de parâmetros, principalmente quando são utilizadas nas análises programas computacionais que não levam em consideração o processo de seleção dos indivíduos. No entanto, quando o tamanho populacional é grande ( $>200$ indivíduos), e o experimento é delineado para um estudo preliminar ele pode ser utilizado, não sendo recomendado inclusive quando o objetivo do experimento inclui várias características ou múltiplos QTLs; nem quando é necessário obter estimações precisas de efeitos genéticos e localizações de loci.

Darvasi \& Soller (1992) consideram que não há um limite absoluto para o número de indivíduos que precisam ser genotipados, e o número ótimo seria aquele compatível com os custos da genotipagem. Desse modo a diferença observada nos valores da característica quantitativa associada com o genótipo do marcador na população selecionada pode ser muito maior que o efeito do QTL quando a população toda é considerada. Entretanto, para estudos de uma única característica, é aconselhável manter o limite entre 5 e $25 \%$ da população (Weller, 2001). No caso da avaliação de peso corporal em frangos (ou qualquer condição que permita formar populações grandes) a proporção ótima estaria entre 5 e $10 \%$ dos indivíduos, devido aos custos de genotipagem em relação à fenotipagem.

Como a proporção ótima de seleção depende dos custos de genotipagem em relação aos custos de crescimento e mensuração de um indivíduo, se a proporção ótima estimada de genotipagens fosse de $25 \%$, isso implicaria em uma quantidade quatro vezes maior de indivíduos fenotipados em relação aos genotipados (Weller, 2001).

Em estudos com animais (Muranty, H. 1996 e 1997; Muranty et al. 1997; Lebowitz et al. 1987; Vallejo et al. 1998; Ohno et al. 2000), têm sido demonstrada a eficiência do uso de genotipagem seletiva para a detecção de QTL tanto em populações endogâmicas quanto não-endogâmicas para diferentes delineamentos. 
Segundo Moody et al. (1999), a genotipagem seletiva é feita dentro de famílias de irmãos completos para eliminar os efeitos que podem ser atribuídos ao "background" genético específico de uma determinada combinação de parentais. Foram selecionados os extremos dentro de famílias de irmãos completos depois de ajustar os dados para efeitos de sexo e lote. Já Yonash et al. (2001) realizaram a genotipagem seletiva dentro da família de fêmeas, utilizando 1 macho F1 com 11 fêmeas. Kirkpatrick et al. (1998) testaram o efeito de fêmeas $F 1$ e ninhada de cada fêmea reprodutora $F 1$ sendo que foi encontrado efeito significativo apenas para a característica de crescimento. A genotipagem seletiva utilizou $12,5 \%$ de cada extremo da população F2.

\subsection{Métodos Estatísticos}

Conceitualmente, no mapeamento de QTL primeiro se faz uma varredura no genoma ou cromossomo com um número grande de marcadores, de forma a selecionar aqueles informativos e com uma análise estatística apropriada identifica-se a região ou regiões que mostram um desvio da média esperada sob hipótese de eventos independentes (Lander \& Kruglyak, 1995). Na prática, diferentes metodologias podem ser utilizadas, sendo que as mais usuais em delineamentos de duas ou três gerações são a análise de variância, regressão e modelos mistos; nas quais a herança do alelo é traçada de pai para progênie. As metodologias para análise são categorizados com base nos modelos genético-estatísticos realizados (Bovenhuis et al., 1997).

\subsubsection{Análise de variância usando marcas simples}

Esta análise é fundamentada na comparação entre as médias das classes genotípicas dos marcadores, podendo ser realizada por meio dos seguintes testes: teste t, regressão linear simples, análise de variância e razão de verossimilhança.

Um método de associação dos marcadores, um a um, com a característica é realizado; uma diferença significativa entre as médias das classes genotípicas dos marcadores indica a existência de pelo menos um QTL associado àquele marcador. Os 
efeitos do marcador genético podem ser testados utilizando-se um teste F. Essas análises são muito simples do ponto de vista computacional uma vez que não é necessário o conhecimento prévio da posição dos marcadores no genoma. Porém apresentam as seguintes desvantagens segundo Liu (1998) e Zeng (1994): o efeito do QTL fica confundido com sua localização, ou seja, não é possível distinguir um QTL de efeito pequeno de um de efeito grande; e não é possível determinar a posição exata do QTL.

Essa metodologia tem sido usada como uma análise preliminar, de modo a determinar regiões potencialmente importantes e eliminar marcas não informativas na população que está sendo estudada.

\subsubsection{Métodos de regressão e mapeamento por intervalo}

O método de mapeamento por intervalo foi proposto por Lander \& Botstein (1989), sendo baseado nas frequências conjuntas de um par de marcas adjacentes e um QTL pontual, flanqueado por essas duas marcas.

$\mathrm{Na}$ derivação dos processos de estimação, a posição do QTL é geralmente representada na forma de sua posição relativa no intervalo entre os alelos o marcador, M1 e M2, (Falconer \& Mackay, 1996).

Os métodos utilizados para o mapeamento por intervalo em populações segregantes são os de regressão e de máxima verossimilhança .

Haley \& Knott (1992) propuseram a utilização de regressão linear múltipla para mapear QTLs no intervalo entre dois marcadores. O modelo proposto pelos autores assume um QTL $Q$, localizado entre dois marcadores co-dominantes (M1 e M2), desenvolvido para mapeamento em geração F2, de um cruzamento entre duas linhagens endogâmicas as quais são carreadoras de diferentes alelos para todos os três loci. A variância dentro das três classes genotípicas do QTL é a mesma e segue a distribuição normal. Assim, a análise é fundamentada na probabilidade de haver um genótipo para o QTL, dados os genótipos dos marcadores flanqueadores.

O método da máxima verossimilhança para a análise de mapeamento por intervalo foi desenvolvida por Lander \& Botstein (1989) e é uma extensão da 
metodologia para marcas simples apresentada por Weller (1986). Esse método utiliza o valor fenotípico para determinar os valores de recombinação, as médias estimadas dos genótipos possíveis no QTL e sua variância, sendo as frequêencias dos genótipos do QTL condicionadas ao genótipo do marcador ligado. Considera que a variância nas 27 classes genotípicas e que os valores fenotípicos do caráter em questão seguem a distribuição normal.

O resultado das duas metodologias, regressão e verossimilhança, são bastante parecidos no entanto o método de regressão é computacionalmente mais simples.

\subsubsection{Análise F2 (linecross)}

Nessa análise, existe a pré-suposição de que duas linhagens fundadoras, mesmo que essas tenham alelos dos marcadores em comum, estão fixadas para alelos alternativos do QTL que está afetando a característica estudada.

Segundo Falconer \& Mackey (1996), considerando uma geração F2 de uma população endogâmica, os efeitos genotípicos dos três possíveis genótipos do QTL serão $m+a$, $m+d, m-a$, para os genótipos $Q Q, Q q$ e $q q$, respectivamente, onde $m$ é a média dos pais (média dos homozigotos), $a$ é o efeito aditivo e $d$ o efeito de dominância. Os valores genotípicos esperados para o QTL, para a classe genotípica, dos marcadores na F2 são obtidos das freqüências esperadas para a classe correspondente, por exemplo, o genótipo homozigoto para os marcadores M1M1M2M2, cuja freqüência esperada é igual a (1c) $)^{2}$ 4: as freqüências esperadas para os três possíveis genótipos do QTL, são 1/4(1$\mathrm{c} 1)^{2}(1-\mathrm{c} 2)^{2}, 1 / 2(1-\mathrm{c} 1) \mathrm{c} 2(1-\mathrm{c} 2) \mathrm{c} 1$ e $1 / 4 \mathrm{c}^{2} \mathrm{c}^{2}$, para os genótipos QQ, Qq e qq respectivamente (Haley et al., 1994). Este procedimento fornece as estimativas para o efeito aditivo $a$ e de dominância $d$, bem como as somas de quadrados e quadrados médios de regressão e desvios, permitindo assim a realização de testes de hipóteses sobre $a$ e $d$. A posição que gerar o melhor ajuste do modelo (menor soma de quadrados dos resíduos) fornece a posição mais provável do QTL, e as melhores estimativas dos seus efeitos. 
O uso de múltiplos marcadores ou intervalos aumenta o poder do teste, quando comparado com a análise de marcas simples ou marcadores flanqueando um único intervalo. $\mathrm{O}$ uso de marcadores múltiplos também diminui o viés nas estimativas da posição e efeito de um QTL que podem acontecer quando num mesmo grupo de ligação, os marcadores possuem diferentes heterozigosidades nos indivíduos Fl (Haley \& Knott, 1992). Esse tipo de mapeamento também pode ser calculado por meio de duas metodologias: a regressão de Haley \& Knott (1992), que é uma extensão da metodologia desenvolvida para o mapeamento por intervalo; e um modelo baseado na verossimilhança de Zeng (1994), onde ele propõe fixar a posição eventual de um QTL dentro do intervalo e em seguida estimar os demais parâmetros.

\subsubsection{Análise de meio-irmãos}

Uma metodologia utilizando mapeamento por intervalo, utilizando vários marcadores, para análise de meios-irmãos foi descrita por Knott et al. (1996). Nesta forma de análise é considerada apenas a relação entre o pai e as progênies, sendo desconsideradas as demais informações de parentesco dentro e entre famílias. A regressão é ajustada dentro de famílias de meio-irmãos porque a associação com o primeiro gameta do pai é aleatória e nem todos os progenitores são heterozigotos para o QTL. Além disso, a fase de ligação entre QTL e marcador pode diferir entre as famílias. $\mathrm{O}$ teste estatístico calculado é um teste $\mathrm{F}$ para cada posição no mapa (intervalo entre o primeiro e último marcador) entre e dentro das famílias (Spelman et al., 1996).

De Koning et al. (1999) utilizaram a combinação das duas metodologias, análise de "linecross" numa população não endogâmica, onde as linhagens fundadoras eram supostamente fixadas para os alelos do QTL e um modelo de meio-irmãos, dentro de família, onde um único efeito de substituição de alelos foi ajustado dentro de cada família de meio-irmãos paternos. Eles demontraram que o uso de ambas análises pode resultar num maior acúmulo de informações, apesar da análise de meio-irmãos ter menor poder de detecção em delineamentos populacionais F2 para "outbreds". 


\subsubsection{Modelos mistos}

Este modelo foi sugerido por Weller (1986) para cruzamentos entre linhagens endogâmicas . As soluções são obtidas pela maximização da função de verossimilhança. Este método pode ser aplicado nas situações em que as informações sobre o genótipo de um indivíduo são incompletas (Lander \& Botstein, 1989).

\subsection{Resultados de mapeamento de QTLs em Gallus gallus}

O frango é um excelente animal para a aplicação da tecnologia de mapeamento genético, devido não somente à sua importância econômica, mas também ao fato do curto intervalo de gerações e da possibilidade de se obter um grande número de famílias de meio-irmãos e de irmãos-completos (Crooijmans et al.; 1996).

Até hoje aproximadamente 1889 marcadores moleculares foram encontrados em aves, entre eles, microssatélites, minissatélites, RFLP (restriction fragment lenght polymorphism), RAPD (random amplified polymorphic DNA) e expression sequence tags (EST), sendo que somente os microssatélites respondem por aproximadamente 800 deles (Groenen et al., 2000).

Uma vez disponibilizados um grande número de marcadore microssatélites cobrindo o genoma todo, foi possível a identificação de vários QTLs, para diferentes características, em aves. A maioria dos trabalhos publicados está relacionada à características de baixa a média herdabilidade. Uma vez que a MAS pode ser usada a partir do mapeamento de QTLs, os estudos têm se concentrado não somente em características quantitativas, mas principalmente aquelas de interesse econômico direto, como resposta imunológica, desempenho e rendimento de carcaça.

Vallejo et al. (1998) utilizando 77 marcadores microssatélites ao longo de todo o genoma, encontraram dois QTLs afetando a susceptibilidade à doença de Marek, nos cromossomos 2 e 8. Outros dois QTLs sugestivos foram encontrados nos cromossomos 4 e 7 para a mesma característica. A população utilizada foi de indivíduos $\mathrm{F} 2$ originados de duas linhagens endogâmicas, uma susceptível e outra não susceptível à doença. 
Também Yonash et al. (2001) estudaram resposta imune em frangos, utilizando 25 marcadores microssatélites, cobrindo $25 \%$ do genoma. Foram encontrados 3 QTLs associados nos cromossomos 2,5 e no grupo de ligação 31 . A diferença é que a população F2 era originada de linhagens não endogâmicas.

Van Kaam et al. (1999a, 1999b) estudaram características de desempenho e rendimento de carcaça, utilizando 420 marcadores microssatélites, abragendo todo o genoma. Nos dois estudos foi encontrado um total de 4 QTLs: um significativo para ingestão alimentar em intervalo fixo de idade e sugestivo para peso vivo aos 48 dias e para crescimento, no cromossomo 1; um sugestivo para ingestão alimentar em intervalo fixo de peso, no cromossomo 2; um sugestivo para ingestão alimentar em intervalo fixo de idade no cromossomo 4 e um último sugestivo para ingestão alimentar em intervalo fixo de idade no grupo de ligação WAU26.

Tatsuda \& Fujinaka (2001) encontraram dois QTLs afetando o peso corporal às 13 e 16 semanas de idade nos cromossomos 1 e 2, numa população também F2 originada de duas linhagens nativas com diferentes ritmos de crescimento, uma 'rapida e outra de crescimento lento. O QTL posicionado no cromossomo 1 encontrado por Tatsuda confirma os resultados encontrados por Van Kaam et al. (1999a) para peso vivo aos 48 dias de idade.

Sewalem et al. (2002) utilizando o peso corporal às 3, 6 e 9 semanas de idade encontraram QTLs significativos em nível de genoma afetando o peso corporal em duas das três idades estudadas, nos cromossomos 1, 2, 4, 7 e 8; e um QTL no cromossomo 13 afetando o peso corporal nas três idades estudadas. Foram utilizados 101 marcadores microssatélites numa população F2 originada de cruzamentos entre uma linhagem de corte e outra de postura.

McElroy et al. (2002), encontraram um QTL no cromossomo 2 para peso da carne do peito à $125 \mathrm{cM}$, identificando um segundo QTL no cromossomo 2. Este último foi diferente dos resultados obtidos para o cromossomo 2 por Tatsuda \& Fujinaka (2001), que encontraram o QTL para peso corporal à $60 \mathrm{cM}$, e por Van Kaam (1999a) à $40 \mathrm{cM}$. 


\section{MATERIAL E MÉTODOS}

\subsection{População experimental}

A população experimental foi desenvolvida na Embrapa Suínos e Aves (Concordia/SC), para mapeamento do genoma avícola. Foram realizados cruzamentos de linhagens diferentes, corte (TT - selecionada por 6 gerações para cracterísticas de corte) e postura (CC - selecionada por 8 gerações com enfase em características de postura), na proporção de um macho para uma fềmea, sendo utilizados 7 machos e 7 fềmeas como "avós". As aves foram mantidas em gaiolas individuais com controle de pedigree e os ovos identificados para possibilitar o anelamento dos pintos da primeira geração, chamados de F1, ao nascer.

Para a formação da segunda geração chamada de F2, a geração F1 constou de 6 famílias de irmãos completos, cada uma contendo 3 machos e 6 fêmeas escolhidos ao acaso da população Fl. As aves foram criadas como matrizes de frango de corte e alojadas em gaiolas individuais. Na fase de reprodução esta população foi reduzida para um macho e três fêmeas aleatoriamente, por família. Cada macho foi acasalado com 3 fêmeas, não parentes próximos, através de inseminação artificial. Cerca de 100 pintos por família foram produzidos num total de 3600 aves (metade de cada sexo), sendo cerca de 1800 por tipo de cruzamento (TC ou CT), ou seja, fềmea de postura com macho de corte, e macho de postura com fêmea de corte, durante 17 incubações. Essa população F2 foi numerada, com controle de pedigree individual, e avaliada para características de crescimento e carcaça (banco de dados do Setor de Melhoramento de Aves da 
EMBRAPA - Suínos e Aves). A estrutura da população pode ser visualizada na Figura 1.

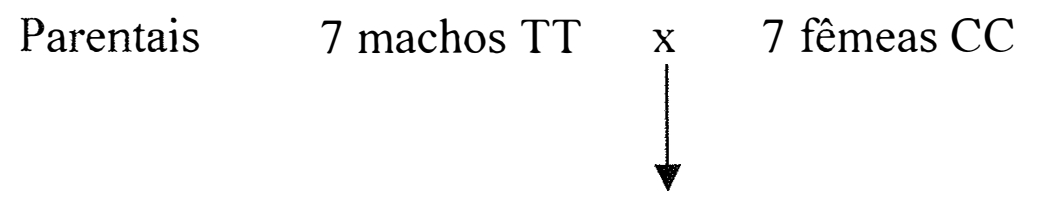

F1

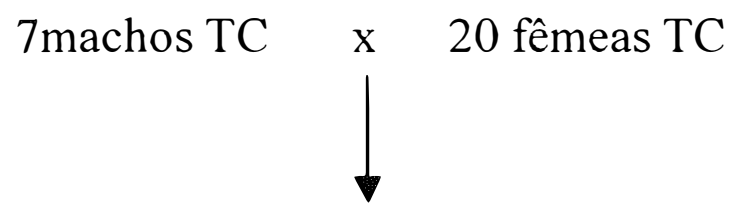

F2
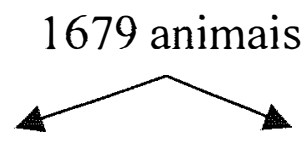

871 machos 808 fêmeas

Figura 1 - Esquema do delineamento de famílias de filhas ou F2 utilizado

Neste estudo foram avaliados somente os animais F1 e F2, provenientes do cruzamento entre machos da linhagem TT, selecionada para corte, e fêmeas da linha CC selecionada para postura, chamado de cruzamento TC.

\subsection{Colheita de dados fenotípicos}

Os dados de desempenho obtidos durante a criação das aves foram: peso vivo aos 35 dias de idade, peso vivo aos 41 dias de idade, e peso vivo aos 42 dias de idade (equivalente ao peso vazio), ganho de peso entre o $35^{\circ}$ e $41^{\circ}$ dias de idade, consumo de ração entre o $35^{\circ}$ e o $41^{\circ}$ dias de idade e conversão alimentar dos 35 aos 42 dias de idade. Após o abate foram colhidos os dados de rendimento da carcaça e partes, pesos dos pulmões, do coração, da moela, e comprimento do intestino. Essa parte do experimento foi conduzida na EMBRAPA - Suínos e Aves. 


\subsection{Coleta de sangue}

Conforme a população experomental referência foi sendo formada, amostras de sangue foram coletadas durante o abate, estocadas em tubos eppendorf $(1,5 \mathrm{~mL})$ e falcon $(15 \mathrm{~mL})$ contendo EDTA $10 \%$ e congeladas para posterior análise de DNA.

Foram coletados $5 \mathrm{ml}$ de sangue da asa (veia braquial, em 3 vezes, aproximadamente $1,6 \mathrm{ml} / \mathrm{semana}$ ou mês) dos parentais e $\mathrm{Fl}$ e ao abate coleta total de sangue após a decapitação das aves F2. O sangue foi coletado em tubos que foram armazenados em freezer a $-80^{\circ} \mathrm{C}$ para posterior extração de DNA. O término dos abates ocorreu em agosto de 2000. Assim que todo o sangue foi coletado foram separadas alíquotas organizadas segundo a família a que pertenciam as aves. Parte desse sangue aliquotado está armazenado no Laboratório de Biotecnologia Animal da ESALQ/USP em Piracicaba, SP, e o restante permanece na EMBRAPA - Suínos e Aves.

\subsection{Extração de DNA}

O processo de extração no início seguiu-se como proposto no projeto, pelo protocolo modificado de Hillel et al.(1989), que consiste de colocar $20 \mu \mathrm{L}$ de sangue em um tubo eppendorf de 1,5 mL. Adicionou-se a cada alíquota $200 \mu \mathrm{L}$ SSC 1X. As amostras foram centrifugadas por 2 minutos a $12000 \mathrm{rpm}$ e descartado o sobrenadante.

As células foram ressuspendidas em mais $200 \mu \mathrm{L}$ de SSC $1 \mathrm{X}$ e repetida a centrifugação descartando em seguida o sobrenadante. Ao pelete foi adicionado $500 \mu \mathrm{L}$ de acetato de sódio sob agitação cuidadosa até dissolver o precipitado. Foram adicionados $50 \mu \mathrm{L}$ de SDS 10\%, misturados por inversão. Em seguida foram adicionados $500 \mu \mathrm{L}$ de PCI (fenol/clorofórmio/isoamil). Os tubos foram invertidos de modo a misturar seu conteúdo e centrifugados a $12000 \mathrm{rpm}$ por 10 minutos. A fase aquosa foi transferida para um tubo novo e extraída novamente com $500 \mu \mathrm{L}$ de PCI. Este procedimento de extração com PCI foi repetido e as amostras centrifugadas novamente. Foi adicionado $1 \mathrm{~mL}$ de álcool absoluto, misturado por inversão; seu conteúdo foi 
deixado para precipitar por uma hora e meia a $-20{ }^{\circ} \mathrm{C}$ ou meia hora a $-80{ }^{\circ} \mathrm{C}$. Os tubos foram centrifugados a $12000 \mathrm{rpm}$ por 2 minutos e descartado o sobrenadante. Foram adicionados $500 \mu \mathrm{L}$ de etanol $70 \%$ sob agitação. Novamente os tubos foram centrifugados a $12000 \mathrm{rpm}$ por 5 minutos e o sobrenadante descartado. Os tubos foram colocados à temperatura ambiente ou $37^{\circ} \mathrm{C}$ por meia hora para secar. $\mathrm{O}$ precipitado foi ressuspendido em $300 \mu \mathrm{L}$ de água ultra pura.

Como esta metodologia não forneceu bons resultados a extração que foi utilizada posteriormente foi a extração por DNAzol ® Reagente (Invitrogen Life Technologies), que consiste aliquotar $15 \mu \mathrm{L}$ de sangue conservado em EDTA e adicionar $1 \mathrm{~mL}$ de DNAzol. O conteúdo do tubo foi agitado manualmente e dividido em dois tubos novos. Foram adicionados novamente a cada tubo $500 \mu \mathrm{L}$ de DNAzol, os tubos foram agitados e seu conteúdo dividido em dois outros tubos. Em cada tubo novo foram adicionados $500 \mu \mathrm{L}$ de etanol absoluto. Os tubos foram invertidos várias vezes, e o DNA foi "recuperado" através de sucção por pipetas para um tubo novo. Em seguida procederam duas lavagens com $1 \mathrm{~mL}$ de etanol 95\%, centrifugando os tubos a $1000 \mathrm{~g}$ por dez minutos entre as lavagens. Na última lavagem, o sobrenadante foi descartado, e os tubos foram colocados para secar o pelete por meia hora a $37^{\circ} \mathrm{C}$ e estes ressuspendidos com $300 \mu \mathrm{L}$ de TE ou água (Ally \& Chomczynski, 1997).

Quando as amostras não solubilizavam em água, mesmo após meia hora a $37^{\circ} \mathrm{C}$, foi feita uma lavagem com clorofórmio:álcool isoamílico (CI), onde foi colocado o mesmo volume ressuspendido $(300 \mu \mathrm{L})$ de CI na proporção 24:1. Foi feita uma centrifugação por cinco minutos a $13.000 \mathrm{rpm}$. A fase aquosa foi retirada para um tubo novo e acrescentados 0,1 vezes o volume de $\mathrm{NaCl} 5 \mathrm{M}(0,1 \times 300=30 \mu \mathrm{L})$. Foi adicionado 2 vezes o volume de etanol absoluto $(660 \mu \mathrm{L})$ e centrifugado por dez minutos a $13.000 \mathrm{rpm}$. O pelete foi seco por meia hora a $37{ }^{\circ} \mathrm{C}$ e ressuspendido nos 300 $\mu \mathrm{L}$ iniciais. Mas somente algumas amostras necessitaram deste processo.

Para amostras onde não se recuperava boa quantidade de DNA (entre 100 e 300 $\mathrm{ng} / \mu \mathrm{L}$ ) optou-se pelo uso de protocolo utilizando proteinase-K e fenol. Esse foi utilizado como última tentativa uma vez que a recuperação de DNA é menor do que nos métodos 
anteriores, no entanto a qualidade compensa, quando a amostra de sangue não é nova ou foi congelada e descongelada várias vezes.

\subsection{Leitura em espectrofotômetro}

Todas as amostras de DNA extraídas foram quantificadas em espectrofotômetro (HITACHI, modelo U-2000) para determinação da concentração segundo instruções do aparelho. Com uma média de extração de $100 \mathrm{ng} / \mu \mathrm{L}$, essas amostras foram padronizadas para a diluição de $20 \mathrm{ng} / \mu \mathrm{L}$. Todo o DNA extraído era submetido à eletroforese em gel de agarose a $1,5 \%$, para ser testado quanto à sua integridade.

\subsection{Escolha dos 53 microssatélites dos cromossomos 2 e 4}

Uma vez que as amostras foram recebidas no laboratório, foi-se procedendo à extração de DNA e sua leitura como descrito acima. Essas amostras eram aliquotadas para a amplificação dos diferentes microssatélites.

Os primers foram escolhidos de acordo com sua disposição nos cromossomos 2 e 4, e seu número variou conforme o tamanho do cromossomo. No entanto, manter o intervalo de 20 cM de distância entre os marcadores como sugerido por Cheng (1997) e Ferreira \& Grattapaglia (1996) nem sempre foi possível, pela indisponibilidade de marcadores moleculares nessas posições ou por não serem os marcadores informativos. Assim, a distância entre eles variou de 2,5 a 49 cM, para o cromossomo 2 e 2,0 a 34 cM para o cromossomo 4. A lista completa dos marcadores escolhidos para os cromossomos 2 e 4, com seus respectivos número de alelos, posição no mapa de ligação e marcação fluorescente estão nas Tabelas 2 e 3.

Os pares de "primers" (também chamados iniciadores) para amplificação de marcadores microssatélites posicionados no mapa consenso 2000 foram doados pelo Chicken Genome Project. 
Os marcadores utilizados foram MCW (Wageningen Agricultural University), LEI (University of Leicester) e ADL (Avian Disease and Oncology Laboratory) tanto para o cromossomo 2 como para o 4 .

Tabela 2. Marcadores microssatélites para o cromossomo 2 com suas respectivas posições em $\mathrm{cM}$, tamanho em pares de bases, marcação fluorescente e número de alelos

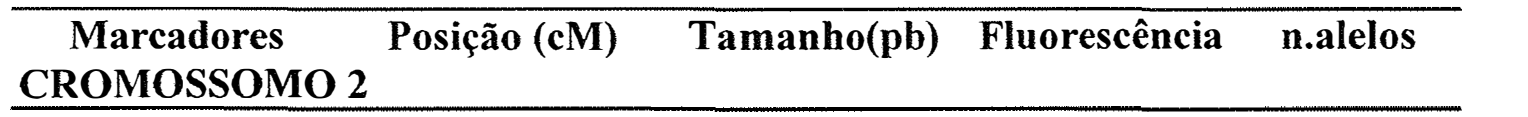

LEI0163

MCW0205

MCW0184

LMU0013

MCW0220

LEI0117

MCW0247

MCW0063

LEI0086

MCW0239

LEI0089

MCW0293

LEI0096

MCW0173

MCW0290

MCW0291

MCW0087

MCW0027

MCW0009

LEI0127

MCW0288

MCW0257

LEI0147

MCW0185

MCW0234

MCW0264

MCW0245

MCW0310

MCW0314

MCW0282

LEI0070

\section{3}

4

60

65

67

70

74

119

114

135

165

182

233

243

245

246

252

255

261

270

275

276

282

304

315

320

364

372

375

378

379
189-207

282-290

240-293

270-280

251-261

192-217

200-212

134-153

233-285

258-170

180-189

224-232

228-246

250-273

190-202

183-191

272-287

123-155

162-174

217-249

118-122

288-301

263-273

200-226

262-269

227-241

284-290

318-320

278-284

287-308

185-223
FAM

HEX

TET

FAM

FAM

FAM

TET

HEX

HEX

FAM

HEX

TET

FAM

HEX

TET

TET

HEX

HEX

FAM

HEX

TET

TET

HEX

TET

TET

HEX

FAM

FAM

TET

HEX

HEX
3

4

6

4

4

4

3

6

5

5

5

3

7

5

2

4

7

6

3

6

3

4

4

3

3

5

2

2

2

3

6 
Tabela 2. Marcadores microssatélites para o cromossomo 2 com suas respectivas posições em $\mathrm{cM}$, tamanho em pares de bases, marcação fluorescente e número de alelos

\begin{tabular}{ccccc}
\hline $\begin{array}{c}\text { Marcadores } \\
\text { CROMOSSOMO 2 }\end{array}$ & Posição (cM) & Tamanho(pb) & Fluorescência & n.alelos \\
\hline & & & & \\
LEI0141 & 382 & $226-250$ & TET & 5 \\
MCW0320 & 392 & $169-177$ & FAM & 4 \\
MCW0324 & 412 & $279-285$ & TET & 3 \\
LEI0104 & 418 & $223-234$ & TET & 4 \\
\hline
\end{tabular}

Tabela 3 - Marcadores microssatélites para o cromossomo 4 com suas respectivas posições em cM, tamanho em pares de bases, marcação fluorescente e número de alelos

\begin{tabular}{ccccc}
\hline $\begin{array}{c}\text { Marcadores } \\
\text { CROMOSSOMO 4 }\end{array}$ & Tam(pb) & Fluorescência & n.alelos & Pos.(cM) \\
\hline MCW0295 C & $94-108$ & HEX & 5 & 75 \\
MCW0251 & $175-177$ & TET & 2 & 87 \\
LEI0100 & $242-274$ & FAM & 2 & 98 \\
MCW0308 & $201-207$ & TET & 2 & 131 \\
LEI0122 C & $289-301$ & HEX & 6 & 132 \\
LEI0144 C & $261-275$ & TET & 4 & 152 \\
MCW0284 C & $238-246$ & TET & 2 & 167 \\
LEI0076 C & $254-280$ & HEX & 5 & 182 \\
LEI0081 & $218-260$ & TET & 5 & 188 \\
MCW0240 & $172-197$ & FAM & 8 & 205 \\
MCW0122 C & $267-277$ & HEX & 6 & 210 \\
LEI0094 & $253-285$ & TET & 5 & 225 \\
LEI0063 C & $206-290$ & HEX & 7 & 227 \\
LEI0085 C & $259-273$ & HEX & 5 & 231 \\
LEI0062 & $81-113$ & FAM & 7 & 239 \\
MCW0099 & $279-310$ & TET & 6 & 242 \\
LEI0073 C & $163-221$ & HEX & 8 & 243 \\
MCW0174 & $261-278$ & HEX & 7 & 252 \\
\hline
\end{tabular}




\subsection{Eletroforese em sequenciador automático A.B.I.377 (Perkin-Elmer) e genotipagem inicial dos animais}

Em uma fase preliminar todos os segmentos amplificados a partir do DNA dos sete machos e vinte fêmeas Fl foram genotipados para os 53 marcadores escolhidos inicialmente, para escolha dos marcadores informativos a serem genotipados nas aves da geração F2.

Assim que foram feitas as amplificações e confirmada a presença das bandas esperadas, de acordo com o intervalo em pares de bases, em eletroforese em gel de agarose $3 \%$, as amostras foram preparadas para a leitura em gel de seqüenciamento e eletroforese no aparelho A.B.I. 377.

Inicialmente, o gel de poliacrilamida $5 \%$ foi feito segundo o protocolo divulgado no curso sobre utilização do sequenciador automático A.B.I. 377 em outubro de 2000. O protocolo consiste em misturar $18 \mathrm{~g}$ de uréia; $26 \mathrm{~mL}$ de água deionizada; "stock solution" de acrilamida Long Ranger TM Gel solution (FMC Bio products); 5,0 $\mathrm{mL}$ de TBE 10X (Tris $\mathrm{HCl}$ 0,9 M; EDTA 0,02 M; ácido bórico 0,9 M); $250 \mu \mathrm{L}$ de persulfato de amônia 10\%; $35 \mu \mathrm{L}$ de TEMED (GIBCO-BRL) para um volume total de solução de $50 \mathrm{~mL}$.

Foram utilizados até 3 marcadores por canaleta do gel. A escolha destes marcadores foi efetuada de modo a combinar fluorescências de marcação e tamanhos esperado em pares de bases da amplificaçãodiferentes. Os primers foram marcados com fluorescência nas cores: azul representada pela marcação "FAM", amarelo "HEX" e verde "TET". O padrão de peso molecular, incluído em todas as amostras para posterior cálculo do tamanho das bandas utilizado pelo programa GENESCAN (Perkin-Elmer), foi indicado pela cor vermelha representado pela marcação "TAMRA". Essas cores correspondiam às denominadas marcações desde que o filtro utilizado no programa $\mathrm{ABI}$ PRIS 377 COLLECTION fosse o filtro C. Foram colocados no início $0,5 \mu \mathrm{L}$ de cada amostra, somando um total de $1,5 \mu \mathrm{L}$ para os 3 marcadores utilizado por canaleta além do padrão de peso molecular TAMRA 350 (pares de bases: 50, 75, 100, 139, 150, 160, $200,250,300,340,350)$ já diluído no "loadding buffer" na quantidade de 4,5 $\mu \mathrm{L}$ (250 
$\mu \mathrm{L}$ de formamida deionizada; $50 \mu \mathrm{L}$ do padrão de peso molecular TAMRA; $50 \mu \mathrm{L}$ de blue dextran). Dessa mistura, que era desnaturada a $95{ }^{\circ} \mathrm{C}$ por 5 minutos e colocada imediatamente no gelo, foram aplicados $1,5 \mu \mathrm{L}$ no gel. Como os primeiros resultados não deram um resultado confiável, as proporções de amostra utilizada foram modificadas. Para este resultado passaram a ser utilizados $1,5 \mu \mathrm{L}$ de cada amostra de cada marcador, e utilizados $9,0 \mu \mathrm{L}$ de padrão de peso molecular TAMRA, sendo aplicado no gel até 2,0 $\mu \mathrm{L}$ dessa mistura após ter sido desnaturada e colocada no gelo.

\subsection{Genotipagem seletiva -Escolha dos indivíduos F2}

Em seguida ao processo de genotipagem dos F1, o produto da PCR foi preparado para eletroforese em gel de poliacrilamida, em seqüenciador automático A.B.I. 377 (Perkin-Elmer), analisado e genotipado pelos programas GeneScan e Genotyper respectivamente (Perkin-Elmer).

Com os alelos presentes nos indivíduos $\mathrm{F} 1$ que formaram a população $\mathrm{F} 2$, identificados (ANEXOS A, B, C, D) foi possível reconhecer os marcadores informativos e assim escolher os melhores marcadores para proceder à genotipagem seletiva.

Assim que os dados fenotípicos dos animais F2 foram recebidos, foi feita uma detalhada conferência com o objetivo de verificar sua consistência, além de conduzir uma análise de estatística descritiva para determinação da média e desvio padrão para a característica de peso vivo aos 42 dias da população.

Os dados corrigidos foram analisados com o auxílio do procedimento "GLM" do pacote estatístico SAS (SAS Institute Inc. Cary, NC, USA), para saber se tínhamos efeitos significativos de sexo, incubação e família para a variável peso vivo aos 42 dias. Todos os efeitos foram encontrados. Para corrigir os pesos e eliminar os efeitos, os animais foram separados em dois diferentes arquivos, um de machos e outro de fêmeas. Os dois arquivos foram analisados com o auxílio do procedimento "GLM" do SAS para ajustar para o feito de incubação tanto em machos como em fềmeas. $\mathrm{O}$ ajuste para incubação foi feito por dois métodos diferentes: 1) ajuste por intercepto para todas as 
incubações de forma geral; 2) ajuste por média de incubação, individualmente. Os dois ajustes deram o mesmo resultado. Em seguida foi realizada uma análise de correlação das 19 características pelo procedimento "CORR" do SAS para determinar qual a melhor característica para ser aplicada na fase preliminar de genotipagem seletiva. $\mathrm{O}$ arquivo de trabalho com os dados devidamente corrigidos e ajustados para o peso vivo aos 42 dias foi assim definido.

Foram então escolhidos $10 \%$ da população, correspondendo a $5 \%$ dos animais mais leves aos 42 dias e os $5 \%$ dos animais mais pesados à mesma idade, dentro de cada família, como pode ser visto no ANEXO E. O número de animais selecionados de 10\% da população foi escolhido também para facilitar as análises de genotipagem no seqüenciador MegaBACE.

Nesta etapa onde só os F2 e os parentais foram genotipados, apenas os marcadores considerados informativos para o maior número de famílias possível, segundo as categorias apresentadas por Hillel (1997), foram posteriormente amplificados e genotipados para os parentais, F1 e parte da progênie F2.

\subsection{Montagem das placas para amplificação e corrida no seqüenciador}

Foram amplificadas e genotipadas duas placas de 96 poços, contendo os produtos amplificados dos 85 animais mais leves e os 85 mais pesados de cada família (2 a 6 animais/família, dentro de cada sexo, dependendo do tamanho da família). Foram genotipados juntos os animais parentais TT e CC formadores da população $\mathrm{F}$ 1, de modo que os alelos presentes nos animais F2 fossem confirmados nos parentais. Este passo é muito importante uma vez que a análise das freqüências dos alelos determinará o próximo passo do projeto. Isso totalizou 192 animais (22 parentais - que se repetiam nas duas placas - e 170 animais F2). Esse número de animais está representando 10,12\% da população de 1679 animais (5,06\% em cada extremo de cada família). 


\subsection{Genotipagem Seletiva - Amplificação pela PCR para os marcadores microssatélites informativos dos cromossomos 2 e 4}

Uma vez que as amostras dos animais F2 foram escolhidas dentro dos $10 \%$ extremos da população, foram feitas as extrações de DNA e sua leitura de concentração no espectrofotômetro como descrito acima. Essas amostras eram aliquotadas para a amplificação dos diferentes microssatélites.

Inicialmente foi realizada a otimização dos programas de PCR segundo as reações apresentadas no site http://www.genome.iastate.edu para que fossem obtidos produtos de PCR em grande quantidade e de qualidade suficiente para serem visualizados no seqüenciador automático com segurança, ou seja, com quantidade de material suficiente para obter uma intensidade de fluorescência dos iniciadores no seqüenciador que permitisse a repetição dos resultados e certeza do genótipo dos animais. Foram escolhidos os protocolos de Cheng et al. (1995) e Crooijmans (2000) para iniciar a otimização da PCR.

Os marcadores foram escolhidos de acordo com o genótipo obtido nos animais F1 e quantidade de famílias em que foram informativos, ou seja, em que o genótipo dos animais $\mathrm{F} 1$ possibilitassem o acompanhamento de determinado alelo, vindo de um ou outro parental, da linhagem TT (corte) ou CC (postura). Foram amplificados todos os microssatélites escolhidos para as 20 famílias, montadas nas duas placas de 96 poços, somando um total de 33 marcadores, sendo que 22 foram do cromossomo 2 e 11 do cromossomo 4.

Os programas de PCR foram otimizados novamente para a genotipagem no seqüenciador MegaBACE. De modo que o programa final com as condições de PCR que melhor obteve resultados para os marcadores microssatélites LEI, MCW e ADL listados nos ANEXOS F e G foi otimizado para o que se segue na Tabela 4: 
Tabela 4. Condições da reação de PCR

\begin{tabular}{cc}
\hline Temperatura $\left({ }^{\circ} \mathrm{C}\right)$ & Tempo \\
\hline 1.94 & 3 minutos \\
2.94 & 1 minuto \\
$3.50 / 55$ & 1 minuto \\
4.72 & 1 minuto \\
5.72 & 5 minutos \\
6.4 & Por tempo indeterminado \\
Número de ciclos & 30 (somente os passos 2 a 4 são repetidos) \\
\hline
\end{tabular}

A temperatura de anelamento (passo 3) variou entre 50 e 55 graus para o grupo de microssatélites de acordo com o respectivo par de iniciadores .

Os iniciadores liofilizados foram diluídos para concentração estoque de 25 pmoles/ $\mu \mathrm{L}$, com a adição de 200 a $400 \mu \mathrm{L}$ de TE (Tris $\mathrm{HCl}$ - EDTA pH 8,0), como recomendado.(Groenen, 2000) As soluções estoque foram diluídas em água milli Q, para uma concentração final de 2,5 pmoles/ $\mu \mathrm{L}$. As condições iniciais de PCR foram: $12 \mu \mathrm{L}$ de reação total; 25-50 ng de DNA genômico; 2,5 pmol de cada primer reverso e direto; 0,2 mM de dNTP; 0,25 unidades de Taq DNA polimerase; $1,5 \mathrm{mM}$ de $\mathrm{MgCl} 2$ e tampão de PCR 1X (Crooijmans et al., 1997). Como a amplificação não foi satisfatória, foram necessárias modificações nas concentrações da reação de PCR, como o aumento no volume de reação para $25 \mu \mathrm{L}$ ao invés de 12 e na quantidade de DNA genômico de 25$50 \mathrm{ng}$ para $100 \mathrm{ng}$ aproximadamente. Além disso para os marcadores $\mathrm{MCW}$ a concentração de primers foi aumentada para 5,0 pmol de cada primer. Essas condições foram mantidas para as amplificações dos animais F2, sendo que somente as condições de temperatura e tempo da PCR foram alteradas para melhor resultado no seqüenciador MegaBACE. 


\subsection{Eletroforese dos produtos da PCR}

Todo o material amplificado foi testado em eletroforese, em gel de agarose variando de $1 \%$ a $2,5 \%$, para verificação do tamanho, da intensidade das bandas obtidas, e o possível aparecimento de bandas inespecíficas. Foram aplicados $10 \mu \mathrm{l}$ de produto da PCR para $2 \mu \mathrm{L}$ de azul de bromofenol por canaleta e $5 \mu \mathrm{L}$ do marcador de peso molecular $\varnothing \mathrm{X} 174$ (Promega ${ }^{\circledR}$ ) era aplicado em cada gel, para comparação do tamanho esperado das bandas.

$\mathrm{O}$ material amplificado era mantido a $-20{ }^{\circ} \mathrm{C}$ até a genotipagem e posterior confirmação dos resultados.

\subsection{Precipitação dos produtos da PCR}

Após a amplificação foi feita a precipitação dos produtos de PCR, que consistia de uma purificação dos fragmentos de PCR para obtenção de melhores resultados na eletroinjeção no seqüenciador MEgaBACE.

Inicialmente foram realizados quatro testes: com protocolo de precipitação utilizando acetato de sódio, protocolo utilizando acetado de amônio, produto de PCR sem precipitação e produto de PCR purificado pelo método de coluna de GFX (GIBCO). As amostras foram aplicadas no seqüenciador e as únicas que deram resultado foram as precipitadas com acetato de amônio.

Dessa forma, os produtos de PCR seguiram o seguinte protocolo: tomar 2,5 $\mu \mathrm{L}$ de cada produto de PCR a ser aplicado em conjunto (até três marcadores poderiam ser genotipados no mesmo capilar); adicionar $1 / 10$ do volume de produto de PCR de acetato de amônio 7,5 M; em seguida adicionar 2,5 volumes de etanol absoluto; misturar bem e deixar descansando por 30 minutos fora da luz; centrifugar por 30 minutos a $3100 \mathrm{~g}$; remover o sobrenadante por inversão; adicionar $150 \mu \mathrm{L}$ de etanol $70 \%$; centrifugar por 10 minutos a $3100 \mathrm{~g}$; remover novamente o sobrenadante por inversão; secar o precipitado por meia hora à temperatura ambiente; ressuspender o precipitado em 4,75 $\mu \mathrm{L}$ de tampão "loading solution" (com formamida) e $0,25 \mu \mathrm{L}$ de marcador de peso 
molecular segundo instruções do aparelho, e vortexar por um minuto para permitir a ressuspensão completa.

As placas foram armazenadas em freezer a $-20^{\circ} \mathrm{C}$, vedadas por adesivo plástico e embrulhadas em papel alumínio até o momento da eletroforese.

\subsection{Eletroforese em seqüenciador automático MegaBACE (Amersham}

\section{Biosystems) e genotipagem dos animais}

Foi realizado em setembro de 2001 o treinamento para a utilização do aparelho, que consiste de um seqüenciador automático com 96 capilares. Nele é possível a genotipagem de 96 amostras em duas horas aproximadamente, com a injeção de até três marcadores por capilar, desde que esses tenham produtos de amplificação de tamanhos diferentes e/ou sejam marcados com fluorescências diferentes. Para o início da eletroforese, um polímero denominado "matrix LPA" é injetado no capilar por pressão de nitrogênio. Ocorre em seguida a eletroinjeção das moléculas de produtos de PCR contidas na placa que está sendo aplicada. É utilizado somente um padrão de peso molecular, e os testes de otimização concentraram-se no tipo de protocolo de precipitação a ser utilizado para preparar as amostras para a corrida, quantidade de DNA a ser utilizado em cada precipitação, voltagem e tempo de eletroinjeção das amostras.

Eram utilizados até três marcadores por capilar por placa, combinados de tal forma que esses tivessem produtos de amplificação de tamanhos diferentes e/ou fossem marcados com fluorescências diferentes. Os iniciadores foram marcados com fluorescência nas cores azul representada pela marcação "FAM", amarelo "HEX" e verde "TET". No entanto, o seqüenciador MegaBACE somente identifica as cores azul e verde, correspondendo aos padrões FAM para a primeira cor e TET e HEX como verdes. Isso ocorre devido aos marcadores microssatélites serem marcados para um tipo de filtro virtual que era utilizado em outro seqüenciador, e o filtro utilizado neste novo seqüenciador reconhecer a cor amarelo com outro tipo e marcação chamada NED. O padrão de peso molecular foi incluído em todas as amostras para posterior cálculo do tamanho das bandas utilizado pelo programa GENETIC PROFILER (Amersham 
Biosystems) e indicado pela cor vermelha representado pela marcação "ROX". Foram colocados no início $3,0 \mu \mathrm{L}$ de cada amostra, somando $9,0 \mu \mathrm{L}$ para os três marcadores utilizados por capilar além do padrão de peso molecular "MegaBACE ET400-R Size Standard" (60, 90, 100, 120, 150, 160, 170, 190, 200, 220, 250, 270, 290, 300, 310, 330, $350,360,380,400$ pares de bases) já diluído no tampão chamado "loadding buffer" na quantidade de $0,5 \mu \mathrm{L}$ de padrão de peso molecular para $4,5 \mu \mathrm{L}$ de tampão. Dessa solução eram misturados $5,0 \mu \mathrm{L}$ com a amostra que foi precipitada, que era então desnaturada a $95{ }^{\circ} \mathrm{C}$ por 1 minuto e colocada imediatamente no gelo até o momento da eletroinjeção. Após otimização, as condições ideais de eletroinjeção dos $5,0 \mu \mathrm{L}$ de amostra precipitada foram $2 \mathrm{kv}$ por 60 segundos, seguidos de $9 \mathrm{kv}$ durante todo o tempo de corrida que foi em média 75 minutos para a entrada do último fragmento do marcador de peso molecular.

Como os primeiros resultados não foram satisfatórios, ocorrendo problemas principalmente de não entrada de amostras nos capilares, ou na análise tamanhos de picos, que identificaram os alelos, muito baixos e de qualidade duvidosa, as proporções de amostra utilizada foram modificadas de forma que se conseguiu um resultado melhor. Para isto, passaram a ser utilizados $2,5 \mu \mathrm{L}$ de cada amostra de cada marcador.

\subsection{Análise de $\chi 2$ (Qui-quadrado)}

Após colheita dos dados de genotipagem no programa GENETIC PROFILER, sua organização em tabelas que permitiam a identificação dos animais $\mathrm{F} 2$ em suas respectivas famílias, verificação da correspondência dos alelos dos parentais com os F2 e identificação dos animais que pertenciam ao grupo dos mais pesados e mais leves, foi feito um teste de dispersão de freqüência que permitisse a identificação de alelos que estivesse segregando de forma diferente para os $5 \%$ mais leves ou mais pesados. O teste usado foi o de Qui-quadrado, por ser um teste que permite caracterizar a freqüência probabilística de uma determinada resposta, que no nosso caso é conhecer se a dispersão da resposta "freqüência dos alelos de um determinado marcador para os subgrupos 
animais leves e animais pesados" se apresenta igualmente ou se a dispersão parece variar dependendo do grupo onde a resposta foi obtida (leves ou pesados). O $\chi 2$ foi calculado da seguinte maneira:

$$
\chi^{2}=\sum_{i=1}^{k} \frac{\left(f o_{i}-f e_{i}\right)^{2}}{f e_{i}}
$$

onde, fo $_{\mathrm{i}}$ e fe $\mathrm{f}_{\mathrm{i}}$ são as freqüências observada e esperada do grupo i, para um total de $\mathrm{k}$ grupos. (Weller, 2001).

\subsection{Determinação de heterozigozidade e PIC}

Para os vinte casais F1 que foram genotipados foram analisadas características como heterozigosidade, número de alelos por marcador e conteúdo de informação de polimorfismo (PIC) para 34 marcadores no cromossomo 2 e 13 marcadores no cromossomo 4, para estudo do comportamento dos marcadores e utilização dessa informação para escolha das famílias a serem genotipadas posteriormente com o objetivo de mapear QTLs.

Utilizou-se o programa CERVUS, versão 2.0, (Copyright Tristan Marshall 19982000) (http://helios.bto.ed.ac.uk/evolgen/cervus/cervus.html).

\subsection{Genotipagem das famílias completas para os marcadores significativos no teste de $\chi 2$ (Qui-quadrado)}

A partir do teste de Qui-quadrado, onde foram identificados os marcadores significativos $(\mathrm{P}>0,10)$, associados a peso vivo aos 42 dias de idade, foram escolhidas as famílias que possuíam os alelos mais informativos para estes marcadores. Dessa forma as famílias utilizadas para a genotipagem do cromossomo 2 não necessariamente eram as mesmas para o cromossomo 4. Esta combinação totalizou 10 famílias de F2 genotipadas para o cromossomo 4 e 9 para o cromossomo 2, para 07 marcadores no 
cromossomo 2 e 06 no cromossomo 4. As reações de PCR, eletroforese em agarose e precipitação foram realizadas como descrito anteriormente para a genotipagem seletiva. A genotipagem das famílias completas para cada marcador também foi realizada no sequenciador automático MegaBACE. A montagem das placas de 96 poços para cada família, seguiu a seguinte ordem: eram colocados primeiramente os quatro parentais, dois da linhagem dos machos (TT) e dois da linhagem das fêmeas (CC); os outros animais eram dos animais $\mathrm{F} 1$, ou seja o casal TC, que correspondia à família escolhida; e por último forma colocados os animais F2. Os F2 foram escolhidos de acordo com a numeração e a incubação a que pertenciam, assim se em uma determinada família existiam muitos F2 na incubação a, mas somente dois na incubação b, eram tomados os dois da incubação b, e o restante da incubação a, de modo a ter sempre o maior número de incubações representadas dentro das famílias. Quando o número de animais F2 disponíveis ultrapassava o número de poços disponíveis, esse critério de equilibrar as incubações era também adotado, assim como o de procurar equilibrar dentro das incubações o número de machos e fêmeas.

\subsection{Construção dos mapas de ligação}

Inicialmente os resultados obtidos eram os da genotipagem seletiva, ou seja, vinte famílias representadas por 6 a 10 filhos por família, para todos os marcadores testados nos cromossomos 2 e 4. Mapas de ligação preliminares foram então construídos utilizando o programa CRI-MAP (Green et al., 1990) somente com estes dados. Em seguida, a identificação dos marcadores mais informativos para as famílias levou a genotipagem dessas famílias, somente para os marcadores que eram siginificativos nos cromossomos 2 e 4 . Com os dados completos das 10 famílias escolhidas para o cromossomo 4 e 9 do cromossomo 2, foi montado o arquivo do programa CRI-MAP (Green et al., 1990). Cada família escolhida possuía em média 100 F2. Como as famílias escolhidas nem sempre eram informativas para todos os marcadores que foram siginificativos, dentro de cada grupo, cromossomo 2 ou 4, foram genotipadas entre quatro e seis famílias, de tal forma que houvesse de 400 a 600 indivíduos genotipados 
por marcador. O programa CRI-MAP foi usado para determinação da ordem do marcadores, de acordo com o maior o valor de LOD score para a respectiva ordem gerada, e as distâncias em cM entre os marcadores para os cromossomos 2 e 4 separadamente, utilizando a função de mapeamento de Kosambi. O programa tem por objetivo a construção rápida e automatizada de mapas de ligação, testando vários marcadores simultaneamente. Para isso se utiliza de genótipos de indivíduos de uma população para marcadores, ordenando e determinando as distâncias entre as marcas - se estiverem em um mesmo grupo de ligação - utilizando as taxas de recombinação.

Primeiramente é necessário que se tenha um computador com sistema linux, para a obtenção da versão gratuita do programa, e sua seguida compilação. Em seguida, foram montados os arquivos no formato requerido pelo programa e utilizada a opção de comando "prepare". Esta opção gera arquivos de ordem e parâmetros que serão utilizados pelo programa, e que podem a qualquer momento, ser alterados pelo usuário. Uma vez detectados os erros de arquivo, e gerados os arquivos necessários, foi utilizado o comando build que ordena os marcadores de um mesmo grupo, ou seja, num mesmo cromossomo, inserindo cada marcador em um intervalo preestabelecido. Esse intervalo é gerado quando utilizamos a opção "prepare" onde os dois marcadores com melhores recombinações e que podem fornecer as melhores informações são primeiramente fixados. Em seguida à ordenação dos demais marcadores, que é feita com a inserção desses na linha de comando "inserted_loci", são verificado os valores de LOD para as ordens encontradas. Quando não foi possível o ordenamento de todos os marcadores, foi utilizado o comando twopoint, opção que pega cada par de marcadores e cria um intervalos para eles, dando o respectivo valor de LOD score. Os valores são analisados de forma a aceitarmos como ordem possível aquela onde esse valor de LOD é maior ou igual a 3. A opção build foi refeita, com a ordem fixada dos marcadores encontrados na opção twopoint com o melhor valor de LOD, e os outros marcadores foram inseridos. Sempre que necessário a ordem dos marcadores foi alterada, para permitir a inserção de todos eles. Quando uma distância do mapa era muito maior do que a esperada pelo mapa consenso, a opção chrompic era utilizada uma vez que ela apresenta para cada indivíduo analisado, as respectivas fases de recombinação, para cada marcador ordenado. Quando 
o número de recombinações era muito maior do que a esperada na população, o genótipo do indivíduo era conferido no programa GENETIC PROFILER (Amersham Biosciences).

\subsection{Análise dos dados fenotípicos}

Antes da análise de QTLs, os dados fenotípicos foram ajustados para os efeitos fixos, sendo testados diferentes modelos. Dentre os modelos utilizados foram testados ajustes utilizando todos os indivíduos F2 das 20 famílias F1 de irmãos completos, somente os animais correspondentes às famílias escolhidas para o cromossomo 2 ou somente os animais correspondentes às famílias escolhidas para o cromossomo 4. Os dados fenotípicos foram analisados considerando um modelo de herança poligênica contendo efeitos fixos de incubação, sexo, família de mães, e as interações desses efeitos fixos. Foram utilizados como covariáveis os pesos vivos ao nascer, aos 35 dias e aos 42 dias de idade, de acordo com a característica influenciada por esses pesos. Os ajustes foram feitos utilizando o procedimento GLM do pacote estatístico SAS.

\subsection{Mapeamento de QTLs}

Dois modelos genéticos foram utilizados para mapeamento por intervalo, ambos empregando métodos de regressão. O primeiro denominado "line cross" (análise de F2), segue a metodologia de Haley et al. (1994), onde se assume que as linhagens fundadoras estão fixadas para os diferentes alelos do QTL. Já a análise de famílias de meio-irmãos chamada "half-sib" segue a metodologia de Knott et al. (1996) onde não há as présuposições sobre o número de alelos do QTL e frequências desses alelos dentro das linhagens fundadoras.

No modelo "line cross", existe a suposição de que as linhagens fundadoras possuem bases genéticas diferentes e possuem alelos alternativos do QTL fixados, mesmo que elas compartilhem alelos dos marcadores. Assim, para todos os indivíduos F2 é analisada a probabilidade de seu genótipo ter sido herdado da linhagem materna ou 
paterna ao longo do cromossomo. Ainda no modelo de "line cross" um efeito aditivo (a) e um efeito de dominância (d) foram estimados utilizando regressão dos fenótipos, onde o efeito aditivo é definido como sendo metade da diferença fenotípica entre os homozigotos e o efeito de dominância como o desvio entre os animais heterozigotos da média dos homozigotos. Para cada $\mathrm{cM}$ do cromossomo o modelo utilizado para a regressão foi:

$$
Y_{j}=m+a p_{a j}+d p_{d j}+e_{j}
$$

Onde Yj é o valor da característica (ajustada para os efeitos fixos e interações correspondentes) para o animal $\mathrm{j}, \mathrm{m}$ é a média da população utilizada, a e $\mathrm{d}$ são os efeitos aditivo e de dominância estimados para um provável QTL numa dada posição, Paj é a probabilidade do animal $\mathrm{j}$ possuir os dois alelos provenientes da linhagem paterna, Pdj é a probabilidade do animal j ser heterozigoto e ej é o erro residual. (Haley et al., 1994).

Um teste para efeitos de um QTL sexo específico foi realizado segundo Knott et al. (1998). O modelo com QTL sexo específico foi aceito se o teste F contra o modelo com efeitos iguais para ambos os sexos foi significativo $(\mathrm{P}<0,05)$.

Além disso foi realizado um teste para efeito de imprinting segundo Knott et al. (1998). O modelo para imprinting foi reparametrizado para realizar um teste direto da contribuição dos alelos paternos ou maternos (De Koning et al., 2000). Para separar a contribuição dos pais foi adicionada uma probabilidade condicional do indivíduo ter herdado alelos do pai ou da mãe, assim o modelo utilizado foi:

$$
Y_{j}=m+a_{p a t} p_{p a t j}+a_{m a t} p_{m a t j}+d p_{d j}+e_{j}
$$

O modelo genético para um provável QTL foi avaliado de acordo com as contribuições dos componentes individuais do modelo completo (efeito materno + paterno + dominância) e a variância residual. A contibuição de um dos componentes foi 
mensurada pelo valor da redução na soma de quadrados total, causada pela adição de cada componente no modelo depois de fixados os demais. A estatística $\mathrm{F}$ foi utilizada para avaliar a significância de cada componente. Essa avaliação permitiu a discriminação entre um QTL com efeito exclusivamente paterno, materno ou com expressão mendeliana. O efeito de imprinting foi aceito se somente um dos parentais teve contribuição significativa e o efeito de dominância não estava presente, ou seja, comparando o modelo completo com o modelo contendo somente um dos componentes. Em seguida o nível de significância e o efeito do QTL foi calculado para o modelo escolhido.

Para o modelo "half-sib" os animais F2 foram agrupados por família paterna, assim foram ignoradas relações de parentesco entre e dentro dos grupos de half-sib. Esta análise utiliza o mapeamento por intervalo para famílias de meios irmãos descrita por Knott et al. (1996). Nesta metodologia os contrastes são feitos entre dois haplótipos de cada macho Fl. Assim, dentro de cada família um QTL com um efeito de substituição alélica é testado para cada cM do cromossomo analisado, seguindo o modelo:

$$
Y_{i j}=m_{i}+b_{i} P_{i j}+e_{i j}
$$

Onde, Yij é o valor para a característica (ajustada para os efeitos fixos e interações correspondentes) para o indivíduo $\mathrm{j}$, que herdou um alelo do macho $\mathrm{i}$, mi é a média para a família de meio irmãos i, bi é o efeito de substituição para um provável QTL, Pij é é a probabilidade condicional do indivíduo j ter herdado o primeiro haplótipo parental e eij é o efeito residual. A regressão é ajustada dentro de famílias porque o primeiro haplótipo considerado é escolhido ao acaso, nem todos os macho são heterozigotos para o QTL e a fase de ligação entre o marcador e o QTL podem diferir entre as famílias. O teste estatístico é calculado como um $\mathrm{F}$ ratio para cada posição no mapa dentro e entre as famílias (De Koning et al., 1999). Uma vez detectado um QTL entre as famílias, valores tabulados de $\mathrm{F}(\mathrm{P}<0,05)$ para cada família individualmente foram utilizados para avaliar qual ou quais famílias estavam segregando para o QTL.

Apesar de calculado como um "F ratio", a distribuição do teste estatístico sob hipótese de nulidade de não existir um QTL é desconhecida tanto para a análise de 
"linecross" como "half-sib". Por essa razão, o nível de significância (threshold) "chromosome-wide" foi determinado empiricamente por permutação para o cromossomo analisado (Churchill \& Doerge, 1994). Dois níveis de significância foram utilizados: 1) nível de significância sugestivo, onde um falso positivo é esperado numa análise do genoma (Lander \& Kruglyak, 1995); 2) nível significativo foi aceito quando o QTL era siginificativo a 5\% para "genome-wide" (Lander \& Kruglyak, 1995).

O P valor em nível de cromossomo para uma ligação sugestiva para o cromossomo analisado igual à contribuição " $r$ " desse cromossomos em relação ao genoma total é obtido pela divisão do tamanho do cromossomo em $\mathrm{cM}$ pelo tamanho total do genoma. O nível de significância no genoma foi obtido a partir do nível de significância no cromossomo seguindo a correção de Bonferroni:

$$
\text { Pgenome }- \text { wide }=1-(1-\text { Pcromosome }- \text { wide })^{\frac{1}{r}}
$$

Onde,

Pgenome-wide $=$ probabilidade de $\alpha$ escolhida (normalmente 5 ou $1 \%$ );

$r=$ tamanho do genoma testado/tamanho do genoma total.

O resultado foi então pareado com os valores de permuta resultantes da análise de QTLs pelo programa QTL Express, e tomado esse valor como referência, chegamos pelos resultados do programa, ao valor da estatística teste, nesse caso teste $\mathrm{F}$, do valor de corte que proporcionará um nível de significância genômico.

Determinado se existe ou não um QTL, se ele foi significativo ou não segundo o ponto de corte estabelecido, verificamos o quanto o QTL explica da variância fenotípica $\left(r^{2}\right)$. Tomamos o melhor modelo estabelecido anteriormente, de acordo com a significância do teste $\mathrm{F}$ para o cromossomo e do menor valor do resíduo, e calculamos da seguinte forma Churchill \& Doerge (1994):

$$
\frac{\text { MSfull } \bmod e l}{\text { MSreduced } \bmod e l}=X \quad \longrightarrow \quad(1-X) x 100=Y \% \text { da variância }
$$


Esta metodologia é computacionalmente mais eficiente que fazer permutações para "genome-wide", já que no método proposto só teriam que ser considerados os cromossomos que tenham evidência de QTL.

Estes níveis de significância são baseados nas análises realizadas para a densidade de marcadores utilizada na população estudada e não no mapa proposto por (Lander \& Kruglyak, 1995). 


\section{RESULTADOS E DISCUSSÃO}

\subsection{Extração de DNA dos indivíduos F2}

$\mathrm{Na}$ extração de DNA de aves pelo processo proposto por Hillel et al.(1989), ocorreram problemas de qualidade e quantidade de DNA extraídos que foram solucionados com a mudança de metodologia.

Devido às hemácias de aves serem nucleadas, segundo o protocolo de Hillel et al. (1989), a quantidade de material liberado devido ao rompimento das células é grande, o que provoca dificuldades na hora de isolar o DNA das proteínas lisadas e consequente recuperação deste DNA. No processo de separação das fases com adição de fenol:clorofórmio, a primeira fase que se forma ficou muito densa, e não foi possível a separação da primeria com a segunda fase, ficando o DNA com impurezas que impediam que esse ressuspendesse nos $300 \mu \mathrm{L}$ de TE $(10 \mathrm{mM}$ de Tris- $\mathrm{HCl}$ e $1 \mathrm{mM}$ EDTA) adicionados no final, nem mesmo quando colocado em banho maria a $37{ }^{\circ} \mathrm{C}$. Assim a otimização desta técnica, de forma a conseguirmos maior quantidade possível de material de boa qualidade, ou seja, livre de proteínas e inibidores de PCR, foi através da extração com o reagente DNAzol @ (Life Technologies INVITROGEN).

Relacionando os dois processos de extração (o inicial e por DNAzol), o protocolo com a utilização de DNAzol se mostrou mais prático, mais barato, mais rápido e eficiente. Isto, considerando a quantidade de amostras que foram extraídas para o estudo que envolve parentais, F1 e F2 genotipados para marcadores dos cromossomos 2 e 4, necessitando muitas vezes de não apenas uma, mas até duas extrações de DNA de cada animal. 
Assim, a extração de DNA dos indivíduos F2 utilizados para a genotipagem foi feita utilizando-se DNAzol ® Reagente (Life Technologies INVITROGEN), o qual obteve os resultados apresentados na Tabela 5:

Tabela 5. Alguns resultados obtidos da extração de DNA utilizando DNAzol

\begin{tabular}{ccc}
\hline Amostras (animais F1) & Concentração de DNA (ng/uL) & Relação 260/280 nm \\
\hline 7972 & 362,6 & 1,720 \\
7971 & 88,6 & 1,718 \\
7812 & 157,5 & 1,825 \\
7978 & 360,6 & 1,904 \\
7810 & 316,7 & 1,726 \\
7709 & 269,8 & 1,795 \\
7816 & 245,8 & 1,823 \\
7755 & 95,2 & 1,940 \\
7771 & 156,8 & 1,807 \\
7975 & 134,3 & 1,794 \\
7977 & 139,5 & 1,776 \\
7822 & 156,2 & 1,816 \\
7797 & 144,0 & 1,833 \\
7769 & 75,6 & 1,816 \\
7716 & 403,2 & 1,764 \\
\hline
\end{tabular}

\subsection{Amplificação pela PCR}

As amplificações por PCR foram satisfatórias para a maioria dos marcadores após os ajustes nas condições para amplificação, que determinaram quantidades adequadas nas reações e programas de temperatura apropriados para cada marcador: ADL, LEI ou MCW. Contudo, nem todos os marcadores apresentados puderam ser utilizados no experimento, visto que alguns se mostraram informativos em um número pequeno de famílias, outros foram homozigotos na população e alguns não amplificaram 
posteriormente à fase inicial de identificação de marcadores informativos. Dentre os iniciadores ("primers") disponíveis, alguns não puderam ser utilizados e portanto não estão apresentados, pois ainda no período de otimização das condições de PCR, o emprego desses iniciadores não resultou em amplificação, a despeito de várias tentativas.

Alguns marcadores foram empregados satisfatoriamente durante a fase preliminar de escolha de marcadores informativos ou durante os testes de condições para amplificação, mas posteriormente se mostraram ineficientes. De forma semelhante, Zhu et al. (2001) relataram dificuldades em amplificar marcadores utilizando iniciadores LEI e MCW sugerindo que talvez o problema fosse ocasionado pelo tempo de estocagem de cerca de dois anos. Os "primers" utilizados no presente estudo foram adquiridos em setembro de 2000 e mantidos liofilizados, sendo que sua síntese havia ocorrido em 1998.

As concnetrações de $\mathrm{MgCl}_{2}$ empregadas neste estudo foram superiores às utilizadas em outros trabalhos, porém a tentativa de redução na maioria das vezes comprometeu a amplificação, confirmando a existência de estreito equilíbrio nas concentrações dos componentes da reação de PCR. A elevada concentração de $\mathrm{Mg}^{++}$ baixou a estringência da PCR, o que possivelmente permitiu que uma grande proporção dos marcadores disponíveis tenha sido amplificada com sucesso, comparativamente aos cerca de dois terços de marcadores amplificados por Zhu et al. (2001).

As amplificações foram conferidas em agarose e em diversas ocasiões foram observadas presenças de bandas inespecíficas. Essas bandas quando presentes em várias posições e com forte intensidade levaram ao descarte das amostras e à nova amplificação do marcador, utilizando temperatura de anelamento mais elevada nos ciclos de PCR. A redução na quantidade de $\mathrm{MgCl}_{2}$ objetivando aumentar a especificidade do "primer" surtiu pouco efeito quando comparada ao ajuste na temperatura.

Quando foi constatada a presença de banda inespecífica pouco intensa, essa amplificação foi aproveitada sendo corrida no seqüenciador automático. No entanto essa amplificação ficava restrita a correr com outros dois marcadores que não estivessem marcados com a mesma cor de fluorescência, evitando assim qualquer tipo de confundimento entre bandas inespecíficas de um marcador e fragmentos de outro de 
Esta análise foi importante para a escolha da estratégia de genotipagem seletiva e para a escolha da característica a ser utilizada para a genotipagem seletiva. De forma geral as correlações genéticas foram maiores do que as fenotípicas para características como PV42 versus PV35, PV41, peito, gordura, fïgado e carcaça. Somente para a característica hematócrito foram observadas correlações genéticas negativas, e correlação fenotípica negativa com figado.

\subsection{PIC e heterozigosidade}

Existem fatores que afetam o poder de deteç̧ão dos QTLs, como número e localização dos genes que afetam a característica, a distribuição dos efeitos dos genes e suas interações, e sua herdabilidade. Também há fatores associados à metodologia como a densidade de marcadores por cromossomo, tipo de população estudada e tamanho da amostragem, número de famílias e tamanho das famílias estudadas (Lander e Botstein, 1989). Assim aumentando o tamanho das famílias estudadas melhoramos o poder do teste mais do que aumentando o número de famílias estudadas. O conteúdo de informação de polimorfismo (PIC) é a probabilidade de um dos pais ser heterozigoto para um locus marcador e o outro ter um genótipo diferente (Botstein et al., 1980). Utilizando o PIC, ou seja, a informação do quanto os marcadores utilizados na análise estão contribuindo seria possível determinar o número de famílias e tamanho das famílias necessários para aumentar o poder de deteç̧ão em experimentos com QTL. Em adição as famílias poderiam ser escolhidas baseadas na heterozigosidade dos pais de forma a aumentar a informação obtida dos marcadores.

Para os 27 animais estudados e os 47 marcadores presentes nos cromossomos 2 e 4 a média de heterozigosidade foi de $71,35 \%$ para os dois cromossomos em conjunto (Tabela 7) (Baron et al., 2001). Quando comparamos com a literatura, vemos que essa média é bastante alta. Zhu et al. (2001) obteve num estudo com 25 indivíduos F1 e 27 marcadores uma média de heterozigosidade de 58,5\%, e Crooijmans et al. (1996) com 17 marcadores microssatélites e 60 animais de linhagens comerciais, obteve frequências alélicas por volta de $5,8 \%$ e porcentagem de heterozigosidade $42 \%$. O polimorfismo 
obtido pelos autores, assim como no presente estudo, foi relativamente alto quando comparado com outra espécies comerciais como suínos e vacas leiteiras. A heterozigosidade estimada foi muito mais alta que a observada, o que foi explicado pelo pequeno número amostral e porque linhagens comerciais não estão em equilíbrio de Hardy-Weinberg, pré-requisito para os cálculos de heterozigosidade, devido ao longo tempo de seleção. Isso mostra a importância de se utilizar para mapeamentos de QTL cruzamentos de duas linhagens distintas. A freqüência de muitos alelos foi baixa também e dois terços deles tinham frequência menor que 0,3 . Selecionando 12 pares de machos e fêmeas com marcadores altamente heterozigotos de uma população de 25 machos e fêmeas, o número de acasalamentos não informativos pode ser reduzido em até 5\%. A falha na genotipagem dos pais originais pode resultar numa diminuição de famílias com marcadores heterozigotos e assim uma redução no número de famílias que serão utilizadas para o mapeamento dos QTLs. Assim a genotipagem dos pais é essencial para análises de mapeamento, e não significa trabalho a mais uma vez que o genótipo dos pais e das progênies são necessários para a construção dos mapas de ligação das populações estudadas e a determinação da segregação na famílias. Os nossos resultados mostraram que no cromossomo 2 para 27 indivíduos $F 1$ genotipados e 34 loci o número de alelos foi de 6,71 e a heterozigosidade média esperada de 0,702 e para o cromossomo 4, 7,85 e 0,725 respectivamente. No estudo de Zhu et al. (2001) o número de alelos por locus ficou em torno de 3,6. Como vemos, apesar dos números serem um pouco altos quando comparados com a literatura, estes são compatíveis. A densidade de marcadores por cromossomo é compatível com a literatura. As médias de PIC para os cromossomos 2 e 4 foram 0,645 e 0,672 respectivamente, indicando que pelo menos $60 \%$ dos loci marcadores são informativos, ou seja, um dos parentais é heterozigoto e o outro possui um genótipo diferente, e isso é confirmado pelo alto número médio de alelos por locus encontrado com os marcadores utilizados. Esses valores são maiores inclusive que os encontrados por Zhu et al. (2001) onde para os 25 animais Fl e 27 microssatélites o PIC foi de 0,45. Estudos futuros podem ser feitos no sentido de verificar se as heterozigosidades esperadas são compatíveis com as observadas, ou se 
ficarão como nos estudos de Zhu et al. (2001) e Crooijmans et al. (1996) mais baixas que as calculadas.

Tabela 7. Valores de heterozigosidade e PIC dos marcadores microssatélites dos cromossomos 2 e 4

Cromossomos N. Microssatélites N.médio de alelos Heterozigosidade

\begin{tabular}{ccccc}
\hline 2 & 34 & 6,71 & 0,702 & 0,645 \\
4 & 13 & 7,85 & 0,725 & 0,672 \\
Média Geral & - & 7,28 & 0,7135 & 0,658 \\
\hline
\end{tabular}

Essa avaliação foi feita utilizando o programa Cervus 2.0 - Allele Frequency Analysis (C) Copyright Tristan Marshall 1998-2001, para o qual foram fornecidos o número de alelos de cada marcador.

\subsection{Genotipagem Seletiva}

A característica escolhida para a genotipagem seletiva foi o PV42 por estar altamente correlacionado com as demais características estudadas (tabela 6). Assim, os marcadores que foram informativos, foram utilizados para genotipagem nos indívíduos F2, selecionados a partir da curva de distribuição normal para a variável PV42. Outras característica estudadas mostraram correlação positiva com PV42, o que permitiria, conforme afirmaram Muranty \& Goffinet (1997) e Bovenhuis \& Spelman (2000), a detecção de QTLs para essas características com alguma redução no poder de teste.

$O$ resultado da análise de $\chi 2$ para a genotipagem seletiva, para 11 marcadores do cromossomo 4 e para 22 marcadores do cromossomo 2 podem ser vistos nas Tabelas 8 e 9. 
Tabela 8. Resultado da análise de Qui-quadrado $(\chi 2)$ para os marcadores do cromossomo 2

\begin{tabular}{|c|c|c|}
\hline Nome do marcador & Posição (cM) & Resultado $\chi 2$ \\
\hline LEI163 & 03 & Não significativo \\
\hline MCW205 & 05 & Não significativo \\
\hline MCW082 & 30 & Não significativo \\
\hline LMU013 & 65 & Significativo a $5,2 \%$ \\
\hline LEI1 17 & 70 & Não significativo \\
\hline MCW063 & 119 & Não significativo \\
\hline MCW239 & 135 & Significativo a $8,8 \%$ \\
\hline LEI089 & 165 & Não significativo \\
\hline MCW293 & 182 & Não significativo \\
\hline ADL373 & 215 & Significativo a $14,3 \%$ \\
\hline LEI096 & 233 & Significativo a $1 \%$ \\
\hline MCW291 & 246 & Significativo a $2,8 \%$ \\
\hline MCW09 & 261 & Não significativo \\
\hline LEI147 & 282 & Significativo a $2,7 \%$ \\
\hline MCW185 & 304 & Significativo a $2,9 \%$ \\
\hline MCW234 & 315 & Não significativo \\
\hline MCW264 & 320 & Significativo a $1 \%$ \\
\hline GCT02 & 349 & Não significativo \\
\hline MCW245 & 364 & Não significativo \\
\hline MCW314 & 370 & Não significativo \\
\hline LEI070 & 379 & Não significativo \\
\hline MCW320 & 392 & Não significativo \\
\hline TOTAL: 22 & & Significativos: 07 \\
\hline
\end{tabular}


Tabela 9. Resultado da análise de Qui-quadrado $(\chi 2)$ para os marcadores do cromossomo 4

\begin{tabular}{ccc}
\hline Nome do marcador & Posição (cM) & Resultado $\chi \mathbf{2}$ \\
\hline MCW295 & 75 & Não significativo \\
MCW251 & 83 & Significativo a 13,9\% \\
LEI100 & $\mathbf{9 8}$ & Significativo a 1,9\% \\
LEI122 & $\mathbf{1 3 2}$ & Significativo a 4, 1\% \\
LEI144 & 152 & Não significativo \\
LEI076 & 182 & Não significativo \\
MCW240 & $\mathbf{2 0 5}$ & Significativo a 2,1\% \\
LEI063 & $\mathbf{2 2 7}$ & Significativo a 1\% \\
LEI085 & $\mathbf{2 3 1}$ & Significativo a 1\% \\
LEI062 & 233 & Significativo a 13,6\% \\
MCW174 & $\mathbf{2 4 6}$ & Significativo a 6,8\% \\
TOTAL:11 & & Significativos: 06 \\
\hline
\end{tabular}

Foram observados para o cromossomo 4 seis marcadores significativos até o limite de 10\%, distinguindo duas regiões possivelmente ligadas a QTLs. Pode ser observado pelo resultado da análise de Qui-quadrado, que os marcadores escolhidos e a estratégia de genotipagem seletiva conseguiu sinalizar algumas possíveis regiões de ligação do QTL com os marcadores compatíveis com as publicações de Tatsuda and Fujinaka (2001), Van Kaam et al. (1999a; 1999b) e McElroy et al (2002).

Para o cromossomo 2 foram cobertos $389 \mathrm{cM}$ de um total de $464 \mathrm{cM}$ durante genotipagem seletiva, sendo o primeiro marcador utilizado LEI163 posicionado a $3 \mathrm{cM} \mathrm{e}$ o último MCW320, a $392 \mathrm{cM}$. No entanto, somente 7 dos 22 marcadores foram significativamente associados a peso vivo aos 42 dias no teste de qui-quadrado $(\mathrm{P}<0,10)$, para regiões com intervalos que variaram de 13 a $98 \mathrm{cM}$ (Figura 2). Pode ser observado que diferentes regiões apareceram, com valores de significância que variaram de 1 a $8,8 \%$. 
Foram cobertos no cromossomo $4,171 \mathrm{cM}$ de um total de $282 \mathrm{cM}$, sendo o primeiro marcador MCW295 posicionado a $75 \mathrm{cM}$ e o último, $\mathrm{MCW} 174$, posicionado a $246 \mathrm{cM}$. Os intervalos entre os marcadores significativos variaram de 4 a $73 \mathrm{cM}$. No cromossomo 4, 6 dos 11 marcadores utilizados foram significativos (Figura 3). Podemos visualizar nesse cromossomo duas regiões distintas com possíveis ligações a QTLs, a primeira entre os marcadores LEI100-LEI122 com intervalos entre eles de $34 \mathrm{cM}$, e em seguida com um intervalo de $73 \mathrm{cM}$ da primeira entre os marcadores MCW174MCW240 com intervalo entre eles de $41 \mathrm{cM}$, com outros 3 marcadores significativos dentro deste intervalo.

Apesar dos diferentes marcadores terem se comportado de maneira significativa, essa pode ser considerada uma análise de marca simples, onde o efeito genético do QTL e sua posição em relação ao marcador ficam confundidos (Liu, 1998). Na análise por intervalos, pelo método de regressão do fenótipo sobre o tipo de mrcador, as estimativas de distâncias do mapa e do efeito do QTL são obtidas pelo genótipo esperado de um suposto QTL como uma função dos genótipos de seus marcadores flanqueadores e sua frequência de recombinação. A posição em que for obtido o maior coeficiente de determinação com o menor quadrado médio do resíduo, será a localização mais provável do QTL e a estimativa do parâmetro "a" é o efeito aditivo do QTL sobre a característica. A significância de tal efeito pode ser testada por valores de $\mathrm{F}$, que indicam se a ligação do marcador com o QTL foi significativa a 1 ou $5 \%$, ou se foi apenas uma ligação sugestiva. Obtido esse valor de decisão, é possível saber se a região está mesmo ligada a um QTL ou está sendo influenciada por um outro QTL presente no mesmo cromossomo.

As localizações em $\mathrm{cM}$ dos marcadores microssatélites para a análise da genotipagem seletiva são aquelas presentes no mapa consenso 2000 (Groenen et al., 2000). Uma vez que a população em estudo possui número de meioses informativas diferente das populações estudadas anteriormente, foram encontradas diferenças na posição desses mesmos marcadores microssatélites. De qualquer forma, segundo Dr. Bovenhuis (comunicação pessoal) é melhor fazer uso do mapa consenso uma vez que esse está baseado num maior número de populações para a estimativa da posição do marcador, e não somente a população estudada. 


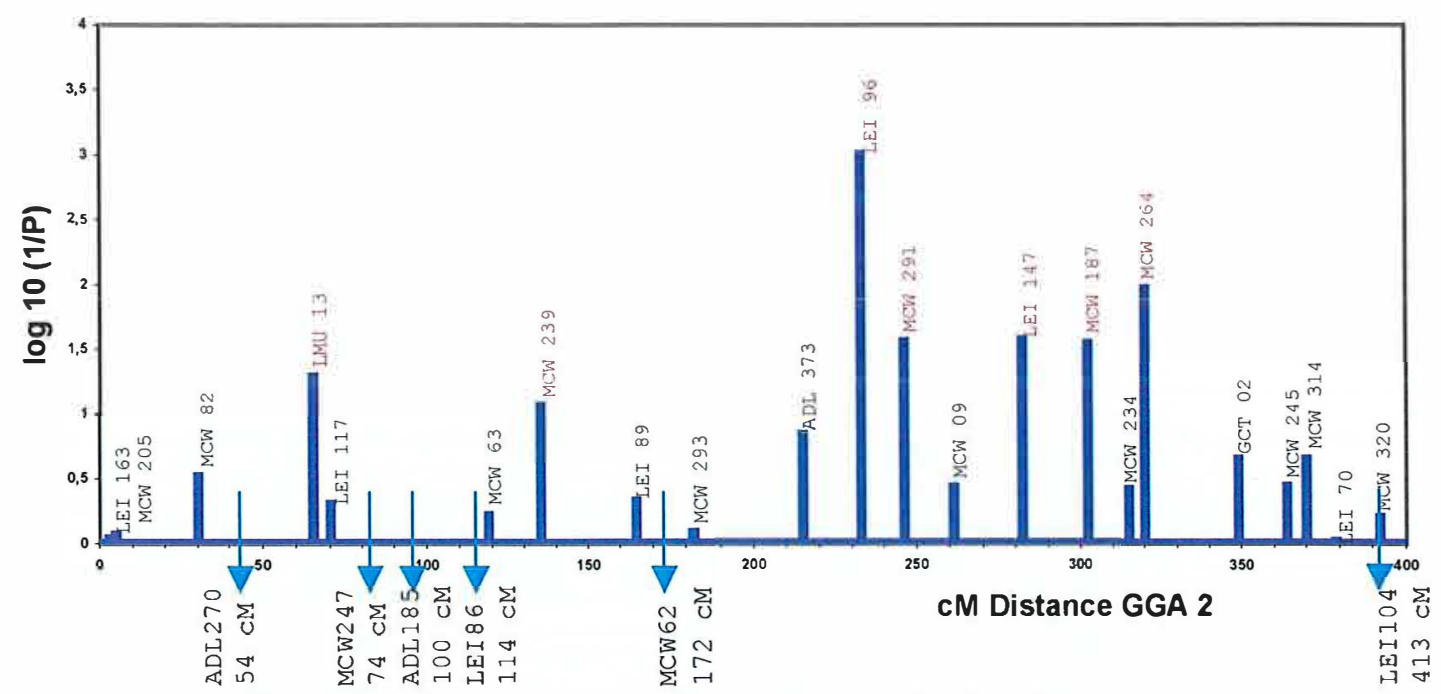

Figura 2 - Marcadores microssatélites testados na genotipagem seletiva para 0 cromossomo 2. Em vermelho estão representados os marcadores que foram significativos no teste de Qui-quadrado $(\mathrm{P}<0.10)$. Em azul estão representados os marcdores que foram testados e incluídos posteriormente na análise de mapeamento para diminuir intervalos entre os marcadores e flanquear marcadores significativos

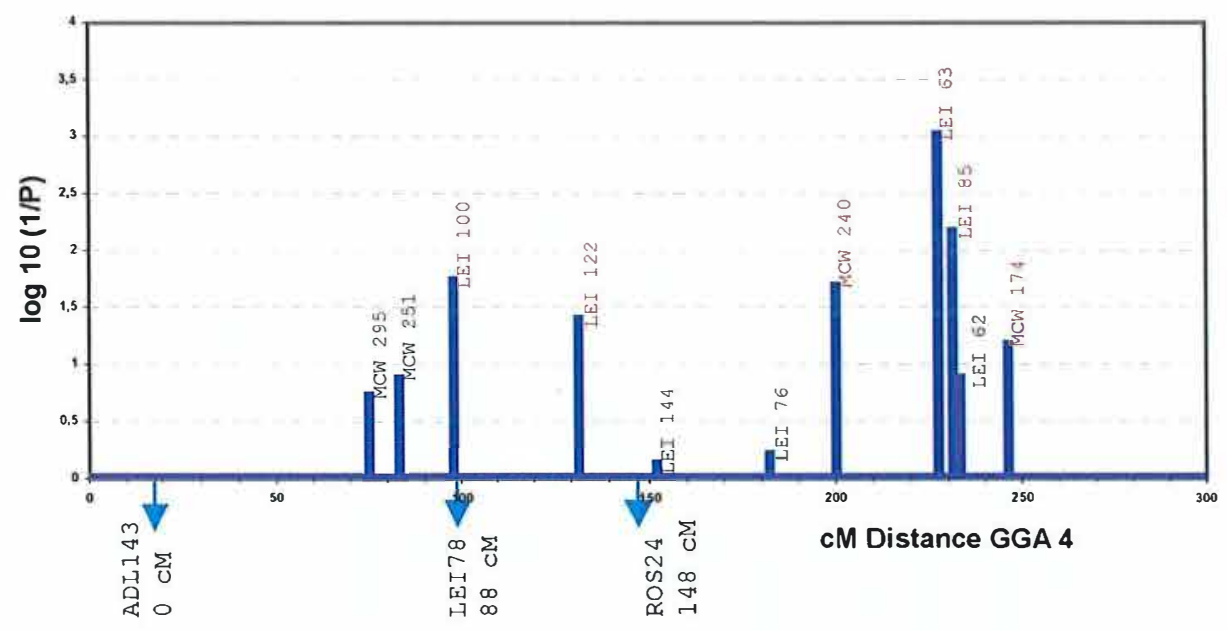

Figura 3 - Marcadores microssatélites testados na genotipagem seletiva para o cromossomo 4. Em vermelho estão representados os marcadores que foram significativos no teste de Qui-quadrado $(\mathrm{P}<0.10)$. As setas em azul indicam os marcadores incluídos para a análise de mapeamento 


\subsection{Escolha de marcadores informativos e genotipagem de famílias completas}

A avaliação da informação dos alelos presentes nos indivíduos F0 e F1, foi feita segundo tabela e critérios de Hillel (1997). Assim nosso objetivo foi escolher famílias para as quais os marcadores significativos fossem informativos, e assim pudessem detectar ligação com o QTL nas análises futuras. Recentes evidências indicam que o nível de heterozigosidade dos microssatélites em linhagens comerciais é menor que 50\% (Crooijmans et al., 1996). De modo a reduzir o número de marcadores a serem genotipados com o mínimo efeito de diminuição do poder do teste, foram criadas categorias para identificar os melhores marcadores dentro de cada família para serem genotipados. Na Tabela 10 são apresentadas as categorias publicadas por Hillel (1997) e que foram utilizadas como base para a escolha de nossos marcadores. Para se obter uma quantidade de meioses informativas que representasse adequadamente as taxas de recombinação, pois com poucos animais esta pode ocorrer de forma tendenciosa, foram selecionadas até seis famílias $\mathrm{F} 1$, ou se não fosse possível, um mínimo de quatro famílias, que possuíam em média 100 filhos cada. Houve preferência pela seleção de famílias aparentadas próximas, ou seja, que o pai F1 fosse comum, obtendo-se assim também famílias de meios-irmãos. Os marcadores significativos, as famílias selecionadas e o número total de F2 para cada marca são apresentados nas Tabelas 11 e 12, para os cromossomos 2 e 4 respectivamente.

Tabela 10. Categorias criadas por Hillel (1997)

\begin{tabular}{cccccc}
\hline \multirow{2}{*}{ Categoria } & Macho & Fêmea & Alelos comuns & \multicolumn{2}{c}{ Informação (\%) } \\
\cline { 5 - 6 } & & & & Macho & Fêmea \\
\hline A & Heterozigoto & Heterozigoto & 0 ou 1 & 100 & 100 \\
B & Heterozigoto & Homozigoto & 0 ou $~$ & 100 & 0 \\
C & Heterozigoto & Heterozigoto & 2 & 50 & 50 \\
D & Homozigoto & Heterozigoto & 0 ou 1 & 0 & 100 \\
E & Homozigoto & Homozigoto & 2 & 0 & 0 \\
F & Homozigoto & Homozigoto & 0 & 0 & 0 \\
\hline
\end{tabular}


Tabela 11. Marcadores utilizados para construção do mapa de ligação, famílias empregadas e número de aves F2 genotipadas por marcador, para o cromossomo 2

\begin{tabular}{cccccccccccc}
\hline Marcador & $\mathbf{7 9 7 2}$ & $\mathbf{7 9 7 1}$ & $\mathbf{7 8 1 2}$ & $\mathbf{7 9 7 8}$ & $\mathbf{7 8 1 0}$ & $\mathbf{7 7 0 9}$ & $\mathbf{7 8 1 6}$ & $\mathbf{7 7 5 5}$ & $\mathbf{7 7 7 1}$ & Fam. & Ind \\
\hline LEI96 & 105 & 107 & 103 & 110 & 88 & $\mathrm{X}$ & $\mathrm{X}$ & $\mathrm{X}$ & 103 & 06 & 616 \\
LMU13 & 105 & 107 & $\mathrm{X}$ & 110 & 88 & $\mathrm{X}$ & $\mathrm{X}$ & 103 & $\mathrm{X}$ & 05 & 513 \\
MCW239 & 105 & $\mathrm{X}$ & 103 & 110 & $\mathbf{8 8}$ & 107 & $\mathrm{X}$ & $\mathrm{X}$ & 103 & 06 & 616 \\
LEI147 & $\mathrm{X}$ & 107 & $\mathrm{X}$ & 110 & 88 & $\mathrm{X}$ & 98 & 103 & 103 & 06 & 609 \\
MCW291 & 105 & 107 & $\mathrm{X}$ & 110 & 88 & $\mathrm{X}$ & $\mathrm{X}$ & $\mathrm{X}$ & $\mathrm{X}$ & 04 & 410 \\
MCW264 & 105 & 107 & 103 & $\mathrm{X}$ & $\mathrm{X}$ & $\mathrm{X}$ & 98 & 103 & 103 & 06 & 619 \\
MCW185 & 105 & 107 & 103 & $\mathrm{X}$ & 88 & $\mathrm{X}$ & 98 & 103 & 103 & 07 & 707 \\
Marcador & & & & & & & & & & & \\
Por família & $\mathbf{0 6}$ & $\mathbf{0 6}$ & $\mathbf{0 4}$ & $\mathbf{0 5}$ & $\mathbf{0 6}$ & $\mathbf{0 1}$ & $\mathbf{0 3}$ & $\mathbf{0 4}$ & $\mathbf{0 5}$ & $\mathbf{x}$ & $\mathbf{X}$ \\
\hline
\end{tabular}

Fam = número de famílias Ind = número de indivíduos

Tabela 12. Marcadores utilizados para construção do mapa de ligação, famílias empregadas e número de aves F2 genotipadas por marcador, para o cromossomo 4

\begin{tabular}{cccccccc}
\hline Famílias & LEI63 & LEI122 & LEI85 & MCW240 & LEI100 & MCW174 & N.marcadores \\
\hline 7972 & $\mathrm{X}$ & $\mathrm{X}$ & $\mathrm{X}$ & $\mathrm{X}$ & $\mathrm{X}$ & 105 & 01 \\
7971 & $\mathrm{X}$ & $\mathrm{X}$ & $\mathrm{X}$ & $\mathrm{X}$ & $\mathrm{X}$ & 107 & 01 \\
7812 & $\mathrm{X}$ & 103 & 103 & $\mathrm{X}$ & $\mathrm{X}$ & $\mathrm{X}$ & 02 \\
7978 & 110 & 110 & $\mathrm{X}$ & 110 & 110 & $\mathrm{X}$ & 04 \\
7810 & 88 & 88 & 88 & 88 & 88 & $\mathrm{X}$ & 05 \\
7709 & 107 & $\mathrm{X}$ & 107 & $\mathrm{X}$ & $\mathrm{X}$ & $\mathrm{X}$ & 02 \\
7816 & 98 & 98 & $\mathrm{X}$ & 98 & 98 & $\mathrm{X}$ & 04 \\
7755 & 103 & 103 & 103 & $\mathrm{X}$ & $\mathrm{X}$ & 103 & 04 \\
7771 & $\mathrm{X}$ & 103 & 103 & 103 & 103 & 103 & 05 \\
7765 & $\mathrm{X}$ & $\mathrm{X}$ & $\mathrm{X}$ & 81 & 81 & $\mathrm{X}$ & 02 \\
N.famílias & $\mathbf{0 5}$ & $\mathbf{0 6}$ & $\mathbf{0 5}$ & $\mathbf{0 5}$ & $\mathbf{0 5}$ & $\mathbf{0 4}$ & $\mathbf{X}$ \\
N.indivíduos & $\mathbf{5 0 6}$ & $\mathbf{6 0 5}$ & $\mathbf{5 0 4}$ & $\mathbf{4 8 0}$ & $\mathbf{4 8 0}$ & $\mathbf{4 1 8}$ & $\mathbf{X}$ \\
\hline
\end{tabular}




\subsection{Construção do mapa de ligação}

Para a construção do mapa de ligação foram utilizados os genótipos das aves submetidas à genotipagem seletiva para os marcadores significativos e também as aves das famílias completas que foram genotipadas para os marcadores significativos no teste de Qui-quadrado. A família 7765 foi a única que esteve presente com 81 progênies no cromossomo 4 e com somente 06 indivíduos da genotipagem seletiva no cromossomo 2; as demais tiveram número igual de progênies nos dois cromossomos.

Os mapas obtidos, como pode ser visto nas Tabelas 13 e 14, foram um pouco diferentes, no que diz respeito às distâncias dos marcadores, daquele publicado como consenso. Isso pode ocorrer devido às diferentes meioses informativas para a população estudada e devido às distâncias entre os marcadores que foram genotipados. Uma forma de conseguir um mapa mais preciso seria adensar, ou aumentar, o número de marcadores (mesmo que não significativos para o teste de Qui-quadrado) nas famílias completas genotipadas.

Tabela 13. Mapa de ligação para os marcadores do cromossomo 2

\begin{tabular}{ccc}
\hline Marcador & $\begin{array}{c}\text { Posição no mapa consenso } \\
\text { (cM) }\end{array}$ & $\begin{array}{c}\text { Posição obtida no } \\
\text { CRI-MAP (cM) }\end{array}$ \\
\hline LMU13 & 62.8 & 62.8 \\
MCW247 & 73.6 & 73.6 \\
LEl86 & 114.4 & 102.5 \\
MCW239 & 126.7 & 127.5 \\
MCW62 & 172 & 170.5 \\
ADL373 & 215.6 & 218.5 \\
LEI96 & 233 & 243.6 \\
MCW291 & 242.3 & 249.4 \\
LEl147 & 282 & 282.1 \\
MCW185 & 302.5 & 297.8 \\
MCW264 & 320 & 313.4 \\
\hline
\end{tabular}


Tabela 14. Mapa de ligação para os marcadores do cromossomo 4

\begin{tabular}{ccc}
\hline Marcador & $\begin{array}{c}\text { Posição no mapa consenso } \\
\text { (cM) }\end{array}$ & $\begin{array}{c}\text { Posição obtida no } \\
\text { CRI-MAP (cM) }\end{array}$ \\
\hline LEI78 & 82.9 & 82.9 \\
LEl100 & 98.4 & 84.3 \\
LEl122 & 132 & 139.2 \\
ROS24 & 148 & 164.2 \\
MCW240 & 200.8 & 198.7 \\
LE163 & 227 & 235.2 \\
LE185 & 231 & 250.1 \\
MCW174 & 246.3 & 280.4 \\
\hline
\end{tabular}

\subsection{Análise de QTLs}

O primeiro marcador utilizado na análise do cromossomo 4 foi o LEI 78, situado a $83 \mathrm{cM}$, flanqueando o marcador LEI100, situado a $98 \mathrm{cM}$ que foi significativo na análise de Qui-quadrado. O último marcador, MCW174, estava situado, pelo mapa consenso a $246 \mathrm{cM}$. Para o cromossomo 2 o primeiro marcador analisado foi o LMU13, situado a $63 \mathrm{cM}$ e o último MCW264, situado a $320 \mathrm{cM}$.

$\mathrm{O}$ intervalo médio entre os marcadores do cromossomo 2 foi de $25,7 \mathrm{cM}$, variando entre 9,3 e 45,3. Para o cromossomo 4 o intervalo médio de 23,4 cM variou entre 4 e $52,8 \mathrm{cM}$.

$\mathrm{Na}$ análise dos resultados foram considerados os QTLs significativos a $1 \%$ no cromossomo, aqueles com ligação sugestiva no genoma, na qual pelo menos 1 falso positivo é esperado no genoma, e os que foram significativoas no genoma a $5 \%$. Para a análise de F2 (linecross), somente os resultados do modelo genético (mendeliano, paterno, materno ou sexo específico) que melhor se adequou aos dados foram apresentados. A escolha do modelo foi baseada na estatística $F$ que avaliou a significância de cada modelo.

Os resultados para a análise de "linecross", indicaram a presença de 10 QTLs no cromossomo 2 e 11 no cromossomo 4 que excediam o nível de significância para ligação sugestiva no cromossomo (Tabela 15). O modelo genético que melhor se adequou aos 
QTLs encontrados foi o modelo mendeliano. Não foi encontrado efeito de imprinting nos QTL apresentados (Figuras 6 e 7).

Tabela 15. Localização e caracterização dos QTLs afetando características de desempenho e carcaça na análise de "linecross", para os cromossomos 2 e 4

\begin{tabular}{|c|c|c|c|c|c|}
\hline Característica & Cromossomo & $\begin{array}{l}\text { Marcadores } \\
\text { (posição, cM) }\end{array}$ & $\begin{array}{c}\text { F-value } \\
(\mathbf{P})^{\mathrm{a}}\end{array}$ & $\mathbf{a}(\mathbf{E P})^{\mathbf{b}}$ & $d(E P)^{c}$ \\
\hline \multirow[t]{2}{*}{ PN } & GGA2 & LEI147-MCW185 (288) & $6,23(0,47)$ & $0,68(0,22)$ & $0,55(0,30)$ \\
\hline & GGA4 & LEI85-MCW174 (237) & $21,06(0,0005)$ & $-1,83(0,29)$ & $2,40(0,59)$ \\
\hline \multirow[t]{2}{*}{ PV42 } & GGA2 & ADL373-LEI96 (216) & $9,06(0,04)$ & $53,45(12,55)$ & $-16,50(20,71)$ \\
\hline & GGA4 & MCW240-LEI63 (224) & $7,48(0,17)$ & $60,65(17,80)$ & $63,88(34,60)$ \\
\hline Pés & GGA4 & MCW240-LEI63 (226) & $7,09(0,24)$ & $0,81(0,21)$ & $0,008(0,39)$ \\
\hline Fígado & GGA4 & LEI100-LEI122 (111) & $4,97(0,82)$ & $0,65(0,27)$ & $-0,99(0,57)$ \\
\hline \multirow[t]{2}{*}{ Moela } & GGA2 & LMU13-MCW247 (63) & $7,60(0,15)$ & $-0,43(0,17)$ & $-0,73(0,25)$ \\
\hline & GGA4 & LEI85-MCW174 (239) & $18,34(0,0005)$ & $1,89(0,31)$ & $-2,03(0,58)$ \\
\hline \multirow[t]{2}{*}{ Peito } & GGA2 & MCW291-LEI147 (280) & $10,00(0,02)$ & $-2,95(0,76)$ & $-3,01(1,11)$ \\
\hline & GGA4 & LEI85-MCW174 (236) & $10,02(0,014)$ & $-4,93(1,10)$ & $3,19(2,35)$ \\
\hline Costas & GGA4 & LEI85-MCW174 (238) & $7,29(0,21)$ & $3,80(1,00)$ & $-2,35(1,97)$ \\
\hline \multirow[t]{2}{*}{ PV35 } & GGA2 & ADL373-LEI96 (217) & $11,23(0,003)$ & $44,81(9,49)$ & $-22,08(16,24)$ \\
\hline & GGA4 & MCW240-LEI63 (224) & $8,91 \quad(0,06)$ & $50,63(13,29)$ & $47,4(25,83)$ \\
\hline \multirow[t]{2}{*}{ PV41 } & GGA2 & ADL373-LEI96 (217) & $8,98(0,046)$ & $54,96(12,96)$ & $-18,40(22,17)$ \\
\hline & GGA4 & MCW240-LEI63 (223) & $7,27(0,16)$ & $54,35(17,45)$ & $78,33(32,56)$ \\
\hline CR35-41 & GGA2 & MCW291-LEI147 (248) & $6,11(0,49)$ & $-14,85(6,01)$ & $21,83(9,80)$ \\
\hline Carcaça & GGA2 & MCW291-LEI147 (280) & $6,99(0,30)$ & $-4,35(1,39)$ & $-4,97(2,03)$ \\
\hline \multirow[t]{2}{*}{$\%$ Gordura } & GGA2 & ADL373-LEI96 (227) & $6,15(0,53)$ & $0,11(0,03)$ & $-0,05(0,05)$ \\
\hline & GGA4 & LEI85-MCW174 (240) & $33,13(0,0004)$ & $0,40(0,05)$ & $-0,43(0,08)$ \\
\hline \multirow[t]{2}{*}{$\%$ Peito } & GGA2 & MCW291-LEI147 (280) & $7,61 \quad(0,19)$ & $0,27(0,07)$ & $-0,002(, 012)$ \\
\hline & GGA4 & LEI85-MCW174 (236) & $6,82(0,34)$ & $-0,39(0,11)$ & $0,18(0,24)$ \\
\hline
\end{tabular}

${ }^{\mathrm{a}}$ Valor de F para cada QTL, sendo o nível de significância de $5 \%$ no cromossomo; P é o nível de significância do QTL no genoma. ${ }^{b} \mathrm{O}$ efeito aditivo é expresso como a metade da diferença fenotípica entre os homozigotos para os alelos da linhagem TT e os animais que são homozigotos para a linhagem CC; EP é o erro padrão para esse efeito. ${ }^{c} \mathrm{O}$ efeito de dominância é expresso como um desvio dos animais heterozigotos em relação à média dos homozigotos das linhagens CC e TT; SE é o erro padrão para esse efeito. 
De modo geral, (Tabela 15) 4 QTLs para o cromossomo 2 foram significativos no genoma, sendo esses para Peito, PV35, PV41 e PV42. O QTL associado com peso nas idades de 35, 41 e 42 dias, foi identificado no intervalo entre os marcadores ADL373 e LEI96 com pelo menos, 5\% de significância no genoma. Esse QTL explicou em média 3,0\% da variação fenotípica para peso corporal. O QTL para peso de peito está entre os marcadores MCW291 e LEI147, explicando 3,4\% da variância fenotípica. No cromossomo 4 as características de peso ao nascer (PN), peso do peito, moela e porcentagem de gordura foram significativas a $1 \%$ no genoma; o peso vivo aos 35 dias (PV35) somente a 6\%. Esses QTLs aparecem no intervalo entre os marcadores LEI85 e MCW174, explicando em média 8\% da variância fenotípica. O QTL para peso vivo aos 35 dias está no intervalo entre MCW240 e LEI63, explicando 3,7\% da variância fenotípica.

Nas análises de meio-irmãos (half-sib), os efeitos dos QTL são alocados dentro de cada família de meio-irmãos e os testes estatísticos foram calculados de um conjunto de soma de quadrados das 4 famílias de meio irmãos. Consequentemente, os valores do teste estatístico, assim como os QTL que alcançaram os níveis de significância foram menores quando comparados àqueles da análise de "linecross". As análises de "half-sib" identificaram 5 QTls no cromossomo 4, sendo que, para as características de peso de fígado, moela e porcentagem de peito os QTL foram confirmados com a análise de "linecross", aparecendo outros dois não identificados anteriormente para comprimento do intestino e hematócrito. Para o cromossomo 2, o QTL para peso vivo foi identificado novamente e apareceram outros dois para pés e gordura, não identificados anteriormente (Tabela 16). O QTL para peso ao nascer, no cromossomo 2 foi identificado à $18 \mathrm{cM}$, podendo ser considerado outro QTL, no entanto temos o marcador LEI147 participando dos dois intervalos. O QTL identificado para figado teve uma mudança significativa de posição, de aproximadamente $40 \mathrm{cM}$, o mesmo aconteceu para o QTL de porcentagem de peito; já para moela temos o mesmo intervalo apesar da posição também ter mudado ligeiramente. As posições em cM para os QTLs são diferentes, entretanto como não foi possível estabelecer um intervalo de confiança para os QTLs, não podemos julgar se estes são os mesmo QTL ou não. 
Tabela 16. Localização de QTLs afetando características de ganho de peso e carcaça que tiveram ligação sugestiva na análise de "half-sib", para os cromossomos 2 e 4

\begin{tabular}{cccc}
\hline Característica & Cromossomo & $\begin{array}{c}\text { Marcadores } \\
\text { (posição, cM) }\end{array}$ & $\begin{array}{c}\text { F-value } \\
(\mathbf{P})^{\mathbf{b}}\end{array}$ \\
\hline PN & GGA2 & MCW291-LEI147 (270) & $4,53(0,17)$ \\
Pés & GGA2 & MCW62-ADL373 (188) & $4,31(0,40)$ \\
Fígado & GGA4 & ROS24-MCW240 (159) & $2,86(0,20)$ \\
Moela & GGA4 & MCW240-LEI63 (201) & $4,11(0,21)$ \\
Comp. Intestino & GGA4 & ROS24-MCW240 (166) & $3,01(0,82)$ \\
Gordura & GGA2 & MCW185-MCW264 (309) & $3,89(0,53)$ \\
Hematócrito & GGA4 & LEI85-MCW174 (238) & $4,64(0,08)$ \\
\%Peito & GGA4 & LEI78-LEI100 (93) & $3,05(0,81)$ \\
\hline
\end{tabular}

${ }^{a}$ Melhor posição no genoma incluindo todas as famílias. ${ }^{b}$ Valor de $\mathrm{F}$ para cada QTL, sendo o nível de significância de 5\% no cromossomo; P é o nível de significância do QTL no genoma.

A concordância de posição e tipo de expressão mendeliana, sugerem um único QTL no cormossomo 2, no intervalo entre os marcadores ADL373 e LEI96 influenciando as características de PV42, PV35, PV41 e porcentagem de gordura. Do mesmo modo, ocorre concordância de posição entre os marcadores MCW291 e LEI147, para peito, porcentagem de peito na carcaça, consumo de ração dos 35 aos 41 dias e peso da carcaça. Para o cromossomo 4 temos duas regiões que parecem apresentar um único QTL cada. A primeira entre os marcadores LEI85 e MCW174 para as características PN, moela, peito, porcentagem de peito, costas e porcentagem de gordura. E a segunda entre LEI63 e MCW240 para PV35, PV42, PV41 e pés. O que está de acordo com as correlações fenotípicas e genotípicas encontradas. Os QTLs, com as respectivas características, posicionados nos intervalos entre marcadores podem ser visualizados nas Figuras 4 e 5. 


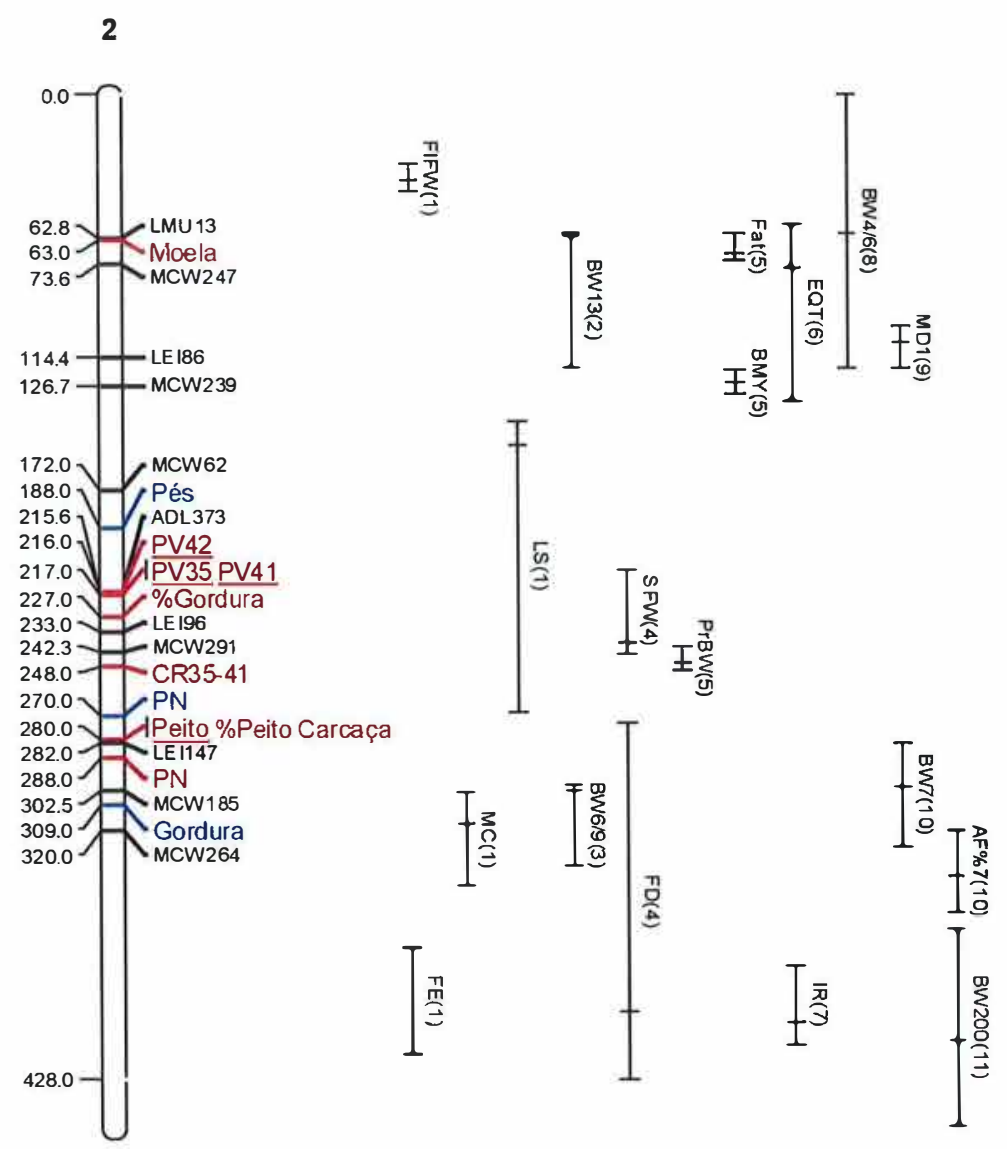

Figura 4 - Mapa dos marcadores e QTLs encontrados no cromossomo 2. Os QTLs foram identificados pelo nome das características correspondentes. Os QTLs encontrados pela análise de "linecross" foram representados em vermelho. Aqueles encontrados sob análise de "half-sib" estão representados em azul. Os QTLs, para as duas análises que foram significativos a $5 \%$ no genoma estão sublinhados. As linhas verticais representam os QTLs encontrados em outros estudos, com os respectivos intervalos entre marcadores. 1) $\mathrm{FIFW}=$ consumo de ração num determinado intervalo de peso; $\mathrm{FE}=$ eficiência alimentar entre 23 e 48 dias; $\mathrm{MC}=$ cor da carne ajustada para peso vivo aos 48 dias (Van Kaam et al., 1999a e 1999b); 2) BW13=peso vivo às 13 semanas (Tatsuda \& Fujinaka, 2001);3) BW6/9=peso vivo às 6 semanas e às 9 semanas (Sewalem et al., 2002); 4) SFW=peso de gordura subcutânea; FD=distribuição de gordura (Ikeobi et al., 2002); 5) Fat=peso de gordura; BMY=porcentagem de peso de peito; PrBW=peso corporal anterior ao transporte (McElroy et al., 2002); 6) EQT=características de qualidade do ovo (Tuiskula-Haavisto et al., 2002); 7) 
$\mathrm{IR}=$ resposta imune (Yonash et al., 2001);8) BW4/6=peso vivo às 4 semanas e às 6 semanas (Siwek et al., 2004); 9) MD1=sobrevivência à doença de Marek (Vallejo et al., 1998); 10) $\mathrm{BW7}=$ peso vivo às sete semanas; $\mathrm{AF} \%=$ porcentagem de gordura abdominal (Jennen et al., 2004); 11) BW200=peso vivo aos 200 dias de idade (Kerje et al., 2003).

\section{4}

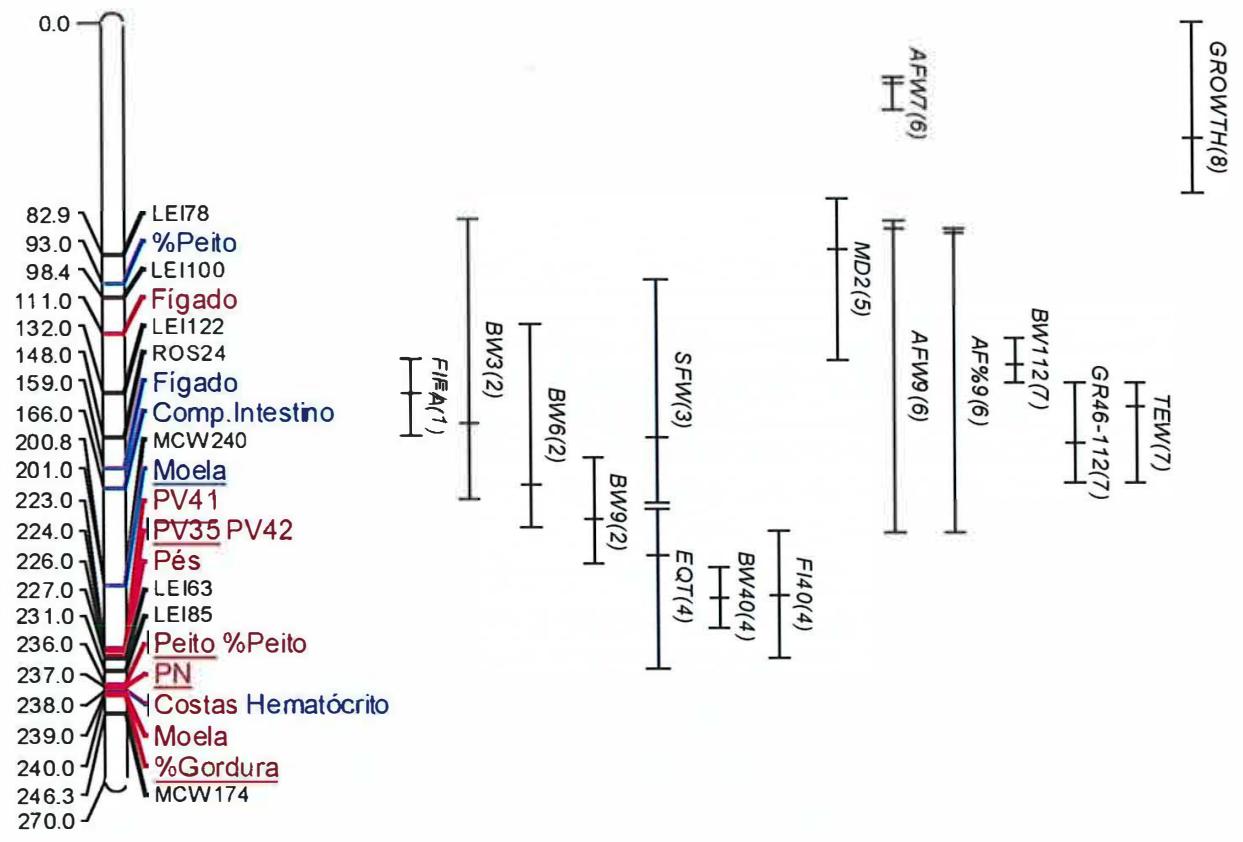

Figura 5 - Mapa dos marcadores e QTLs encontrados no cromossomo 4. Os QTLs foram identificados pelo nome das características correspondentes. Os QTLs encontrados pela análise de "linecross" foram representados em vermelho. Aqueles encontrados sob análise de "half-sib" estão representados em azul. Os QTLs, para as duas análises que foram significativos a $5 \%$ no genoma estão sublinhados. As linhas verticais representam os QTLs encontrados em outros estudos, com os respectivos intervalos entre marcadores. 1) FIFA=consumo de ração num determinado intervalo de idade (Van Kaam et al., 1999b); 2) BW3/6/9=peso vivo às 3, 6 e 9 semanas (Sewalem et al., 2002); 3) SFW=peso de gordura subcutânea (Ikeobi et al., 2002); 4) BW40=peso vivo às 40 semanas; FI40=consumo de ração de 32 à 36 semanas de idade; 
EQT $=$ características de qualidade do ovo (Tuiskula-Haavisto et al., 2002); 5) MD2=número de tecidos afetados por tumor (Vallejo et al., 1998); 6) AFW7 e AFW9=peso vivo às sete semanas e às nove semanas respectivamente; $\mathrm{AF} \%=$ porcentagem de gordura abdominal às nove semanas (Jennen et al., 2004); 7) BW112=peso vivo aos 112 dias de idade; GR46-112=ganho de peso médio entre 46 e 112 dias; TEW=produção total de ovos (Kerje et al., 2003); 8) GROWTH=características relacionadas à peso corporal em população comercial (De Koning et al., 2003).

Comparando este estudo com outros, Sewalem et al. (2002) encontraram QTL posicionado a $177 \mathrm{cM}$, no intervalo entre ADL266 (138 cM) e LEI73 (243 cM) associado a peso corporal às seis semanas, no cromossomo 4. O QTL identificado por Sewalem et al. (2000) pode corresponder ao encontrado para PV42 à $224 \mathrm{cM}$, no intervalo entre MCW240 (200 cM) e LEI63 (227 cM), na nossa população. Essa suposição se dá pleo fato do QTL encontrado para PV42 estar inserido no intervalo de confiança encontrado por Sewalem et al (2002).

Outros QTLs foram encontrados para diferentes características ainda no cromossomo 4. Van Kaam et al. (1999a; 1999b), detectaram um QTL com pico na posição de $147 \mathrm{cM}$, para características de desempenho e conversão alimentar entre os marcadores MCW85 e LEI122. Na nossa população, na mesma região foi identificado um QTL para fígado. Esse QTL poderia estar relacionado com a conversão alimentar se o peso do fígado for correspondente à sua capacidade funcional já que a capacidade de armazenamento de glicogênio pelo fígado, por exemplo, vai estar interferindo na conversão alimentar. De Koning et al. (2003) escolheram para seu estudo o cromossomo 4, assim como Van Kaam et al. (1999 ${ }^{\mathrm{a}}$ ), Sewalem et al. (2002) e Tuiskula-Haavisto et al. (2002), encontrando QTLs em diferentes posições, um QTL afetando consumo à esquerda do marcador ADL194 e outros dois afetando diferentes aspectos de crescimento na mesma região, aproximadamente $40 \mathrm{cM}$.

Para o cromossomo 2, Van Kaam et al. (1999a; 1999b), encontraram um QTL com picos nas posições de 345 cM para coloração da carne, entre os marcadores 
MCW185 e MCW234. No nosso estudo envolvendo o marcador MCW185 foi identificado um QTL para peso ao nascimento, mas a quase $100 \mathrm{cM}$ de diferença do encontrado por Van Kaam et al, (1999b). Na posição de 369 cM para características que afetam a carcaça foi identificado pelos autores um QTL entre os marcadores MCW264 e ADL164, e ainda no cromossomo 2 na posição de $41 \mathrm{cM}$ entre os marcadores MCW82 e MCW245 para características de desempenho e conversão alimentar. Nessas posições somente foi encontrado um QTL a $63 \mathrm{cM}$ entre os marcadores LMU13 e MCW247 para moela. É conveniente lembrar que nos estudos de Van Kaam et al. $\left(1999^{a}, 1999 b\right)$ as análises utilizadas foram de mapeamento por intervalo, utilizando regressão num modelo genético de "full-sib" ou irmãos completos. E os níveis de significância foram derivados do uso de permutação e pela correção de Bonferroni. A mesma metodologia utilizada neste estudo. Kerje et al. (2003) e Jennen et al. (2004) estudaram também características de desempenho. Foi encontrado por Jennen et al. (2004), pela análise de "linecross" por regressão, QTLs com ligação sugestiva no cromossomo 2 para peso vivo às 7 semanas de idade e porcentagem de gordura abdominal, entre os intervalos dos marcadores LEI147-MCW96 e MCW264-ADL164, respectivamente. No entanto, na nossa população foi possível identificar um QTL para peso de gordura, com ligação sugestiva, pela análise de "half-sib", à 309 cM, no intervalo entre MCW185 e MCW264. Tanto Kerje et al. (2003) quanto Jennen et al. (2004) encontraram QTLs para desempenho no cromossomo 4. Kerje (2003) identificou duas regiões com ligação sugestiva para peso vivo aos 112 dias e ganho de peso médio entre 46 e 112 dias, sendo a primeira posicionada à $122 \mathrm{cM}$ e o segundo à $150 \mathrm{cM}$. Ambas foram consideradas pelos autores um único QTL. Essa última região reportada não foi identificada por Jennen et al. (2004), no entanto os autores identificaram um QTL com ligação sugestiva para peso da gordura abdominal às 7 semanas, à $22 \mathrm{cM}$ e outras duas regiões, também com ligação sugestiva para peso e porcentagem de gordura abdominal às 9 semanas, à 71 e $75 \mathrm{cM}$ respectivamente, que foi considerado pelo autores como um único QTL. O QTL encontrado por Jennen et al. (2004) para o cromossomo 4, foram também encontradas por Ikeobi et al. (2002). 
Em geral os resultados das análises de "linecross"e "half-sib" mostram pequena correspondência, o que é esperado quando se faz a análise de meio-irmãos por famílias paternas. No caso de um QTL mendeliano analisado num modelo "linecross", a variância explicada pelo modelo é máxima (De Koning et al., 2001). Quando o mesmo QTL é analisado por um modelo de meio irmãos por famílias paternas a variância explicada será máxima de acordo com a proporção de machos F1 que são heterozigotos para o QTL. Para um QTL mendeliano aditivo que está fixado para alelos alternativos em duas populações fundadoras, a variância explicada pelo QTL na análise de "linecross" é duas vezes maior que utilizando o modelo de "half-sib". Se este QTL for completamente dominante a variância explicada pode ser 3 vezes maior em um modelo que no outro. Quando as linhas fundadoras não são completamente fixadas ou possuem os alelos do QTL segregando em igual frequência, somente o modelo de half-sib é capaz de detectar QTLs. No entanto em populações, como as duas utilizadas neste estudo, possuem provavelmente um nível moderado de alelos compartilhados, é esperado que o modelo de linecross tenha maior poder de detecção de QTLs. Nesse caso, o modelo de linecross é capaz de detectar QTLs que explicam diferenças fenotípicas entre as linhagens, enquanto que o modelo de half-sib detecta QTL que estão explicando diferenças fenotípicas dentro das linhagens e não entre elas. De qualquer forma as duas análises devem ser consideradas separadamente, e diferem em seu modelo genético para a análise (De Koning et al, 2003).

Até este estudo não foi possível identificar algum gene candidato nas regiões onde foram encontrados QTLs. A maior razão para isso é o fato das regiões onde foram identificados QTLs ainda serem muito amplas em relação à distâncias em centiMorgans. O ideal é que os intervalos de confiança para os QTLs fossem reduzidos pela metodologia de "fine mapping", ou seja, aumentar o número de marcadores, com distâncias menores entre eles do que as que foram utilizadas. 


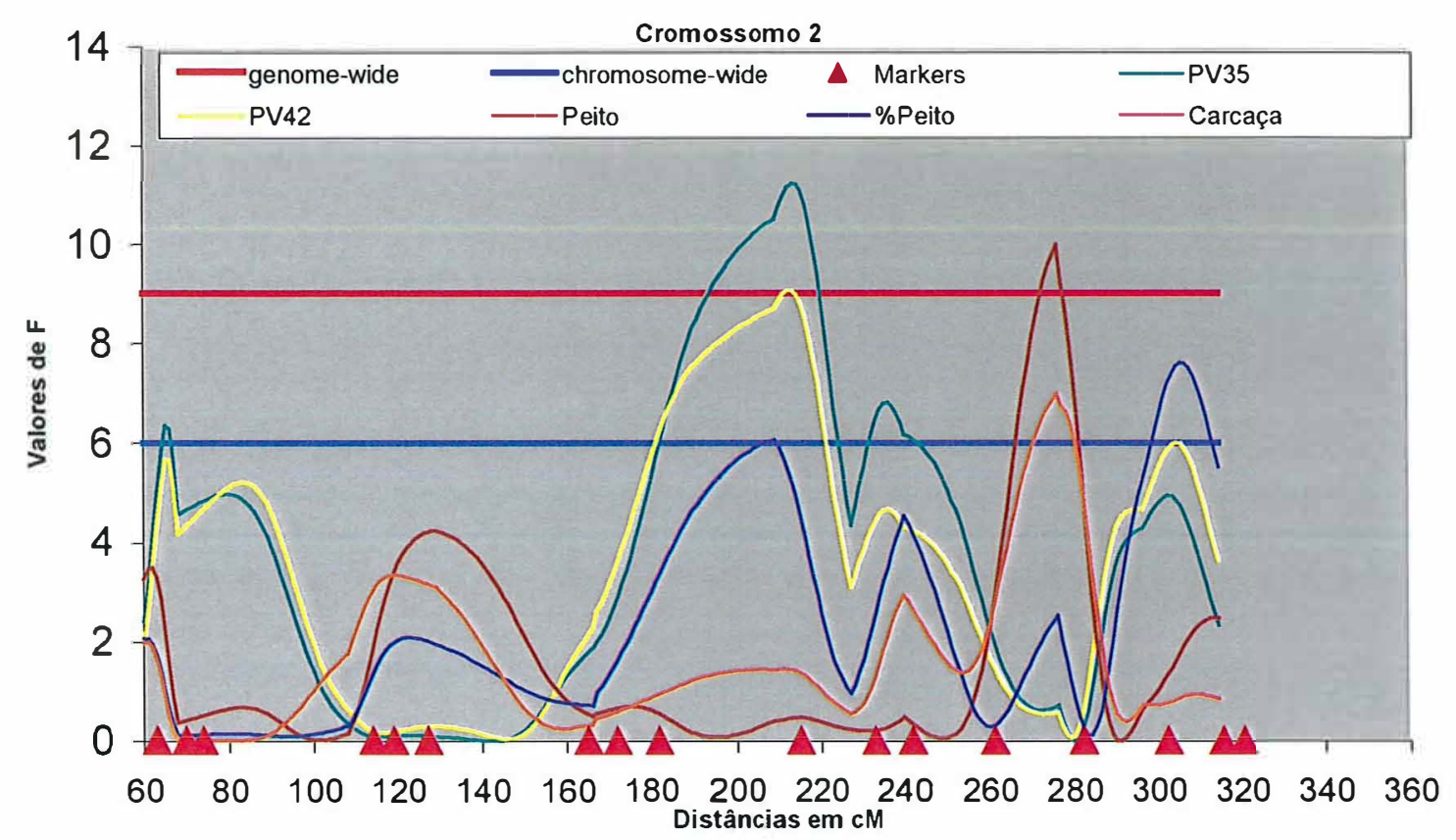

Figura 6 - Curvas do mapeamento de QTLs para o cromossomo 2 sob análise de "linecross". "Genome-wide" é o nível de significância a 5\% no genoma; "Chromosome-wide" é o nível de significância a 5\% no cromossomo; "markers" são as posições dos marcadores; PV35 é o peso vivo aos 35 dias; PV42 é o peso vivo aos 42 dias; Peito é o peso do peito; \%Peito é a porcentagem do peso do peito em relação ao peso vivo aos 42 dias; Carcaça é a soma dos pesos das partes. 


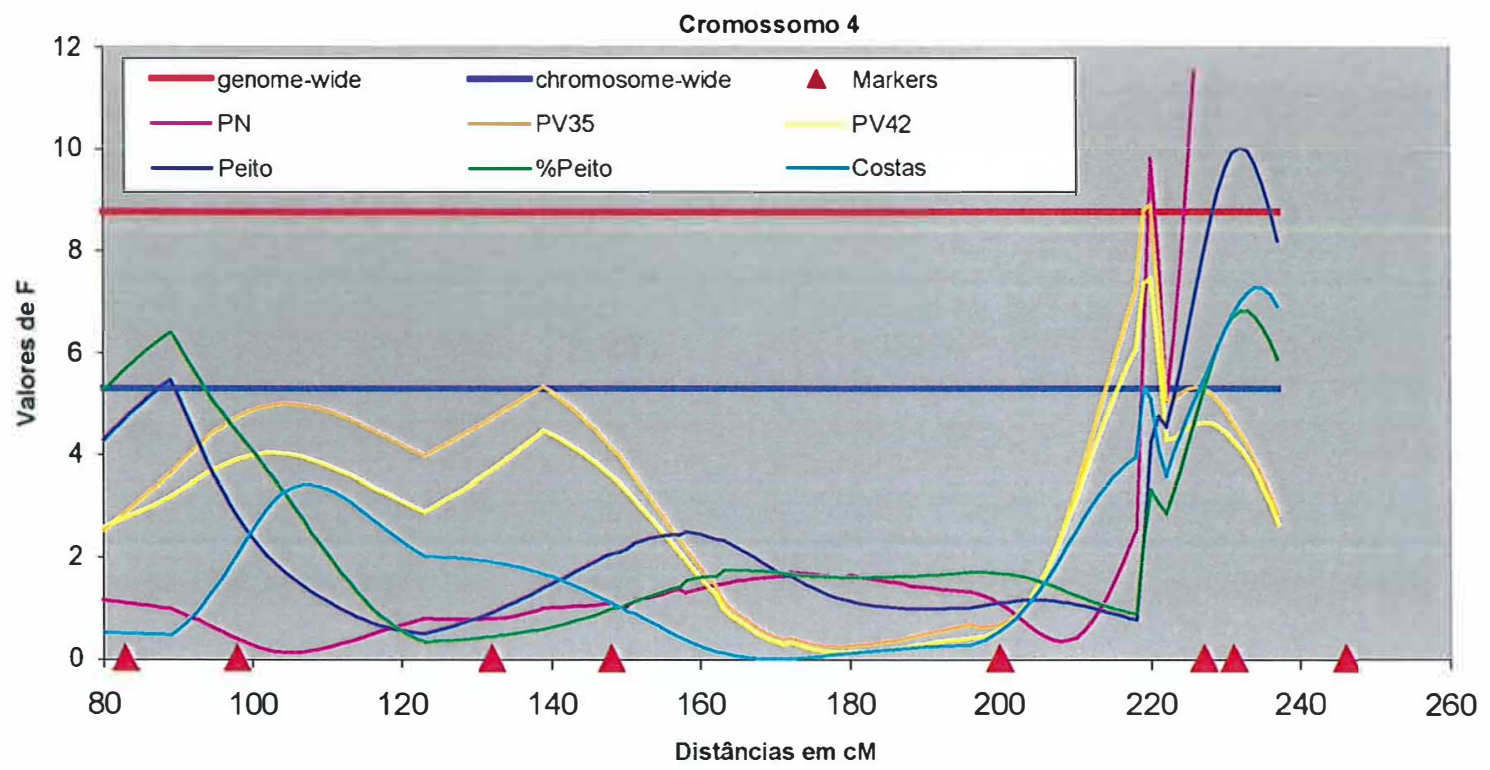

Figura 7 - Curvas do mapeamento de QTLs para o cromossomo 4 sob análise de "linecross". "Genome-wide" é o nível de significância a 5\% no genoma; "Chromosome-wide" é o nível de significância a 5\% no cromossomo; "markers" são as posições dos marcadores; PN é o peso ao nascer; PV35 é o peso vivo aos 35 dias; PV42 é o peso vivo aos 42 dias; Peito é o peso do peito; \%Peito é a porcentagem do peso do peito em relação ao peso vivo aos 42 dias; Costas é o peso da carcaça sem os órgãos, coxa, asa, cabeça e peito. 


\section{CONCLUSÃO}

Pode-se conlcuir que:

1. Os mapas de ligação construídos para os cromosssomos 2 e 4 , utilizando as informações da população experimental desenvolvida na EMBRAPA, corroboraram os mapas publicados até o momento para outras populações estudadas;

2. As estratégias de genotipagem seletiva e escolha de famílias mais informativas para os marcadores nos dois diferentes cromossomos, foram eficientes para identificar, QTLs, nos cromossomos 2 e 4, tanto sob análises de "linecross" como "half-sib".

3. Para nossa estrutura populacional a análise de "linecross" teve maior poder de detecção de QTLem relação à análise de "half-sib", no que diz respeito ao número de QTLs encontrados e desses quantos foram significativos no genoma. 
ANEXOS 


\section{ANEXO A}

Tabela dos genótipos dos machos F1 para os marcadores microssatélites do cromossomo 2. As primeiras colunas correspondem à numeração dos animais machos.

\begin{tabular}{|c|c|c|c|c|c|c|c|c|c|c|c|c|}
\hline Animais & LEI0070 & LE10086 & LEI0089 & LE10096 & LEI0104 & LEI0117 & LEI0127 & LEI0141 & LEI0147 & LEI0163 & LMU0013 & MCW009 \\
\hline 7716 & $191 / 197$ & $249 / 249$ & $186 / 190$ & $240 / 240$ & $219 / 223$ & $208 / 212$ & $243 / 247$ & $230 / 242$ & $263 / 273$ & $189 / 207$ & $272 / 272$ & $172 / 172$ \\
\hline _7769 & $191 / 191$ & $249 / 253$ & $249 / 253$ & $236 / 236$ & $219 / 223$ & $212 / 212$ & $227 / 227$ & $230 / 230$ & $271 / 271$ & $189 / 207$ & $272 / 272$ & $160 / 160$ \\
\hline _ 7797 & $205 / 205$ & $249 / 251$ & $180 / 194$ & $224 / 240$ & $219 / 223$ & $194 / 194$ & $221 / 243$ & $224 / 230$ & $263 / 267$ & $189 / 189$ & $272 / 272$ & $172 / 172$ \\
\hline _ 7822_ & $181 / 205$ & $229 / 251$ & $194 / 198$ & $234 / 234$ & $219 / 219$ & $214 / 216$ & $227 / 227$ & $222 / 222$ & $263 / 273$ & $189 / 189$ & $272 / 272$ & $164 / 164$ \\
\hline _.7975 & $183 / 187$ & $229 / 253$ & $194 / 194$ & $194 / 194$ & $219 / 219$ & $214 / 214$ & $243 / 247$ & $230 / 230$ & $263 / 267$ & $189 / 189$ & $272 / 278$ & $172 / 172$ \\
\hline _7977_ & $221 / 223$ & $229 / 229$ & $198 / 198$ & $240 / 240$ & $219 / 223$ & $214 / 216$ & $227 / 227$ & $230 / 230$ & $267 / 267$ & $189 / 189$ & $272 / 272$ & $172 / 172$ \\
\hline _7985 & $201 / 205$ & $229 / 239$ & $196 / 196$ & $224 / 224$ & $223 / 223$ & $194 / 194$ & $227 / 239$ & $230 / 230$ & $263 / 267$ & $189 / 205$ & $272 / 272$ & $164 / 172$ \\
\hline
\end{tabular}

\begin{tabular}{|c|c|c|c|c|c|c|c|c|c|c|c|c|}
\hline Animais & MCW027 & MCW063 & MCW087 & MCW173 & MCW184 & MCW185 & MCW205 & MCW220 & MCW234 & MCW239 & MCW245 & MCW247 \\
\hline 7716 & $133 / 137$ & $148 / 148$ & $270 / 270$ & $243 / 243$ & $270 / 270$ & $196 / 196$ & $286 / 290$ & $257 / 257$ & $261 / 261$ & $166 / 166$ & $288 / 288$ & $204 / 210$ \\
\hline 7769 & $121 / 145$ & $138 / 138$ & $272 / 280$ & $241 / 241$ & $240 / 242$ & $196 / 196$ & $286 / 290$ & $257 / 257$ & $259 / 259$ & $166 / 166$ & $282 / 288$ & $210 / 210$ \\
\hline _ 7797 & $145 / 145$ & $148 / 148$ & $280 / 284$ & $249 / 249$ & $244 / 244$ & $202 / 202$ & $290 / 290$ & $257 / 257$ & $261 / 271$ & $160 / 166$ & $282 / 288$ & $198 / 204$ \\
\hline _7822 & $139 / 153$ & $138 / 138$ & $272 / 280$ & $249 / 249$ & $288 / 288$ & $196 / 196$ & $286 / 290$ & $257 / 257$ & $263 / 263$ & $166 / 166$ & $288 / 288$ & $204 / 204$ \\
\hline _7975_ & $135 / 135$ & $138 / 158$ & $280 / 184$ & $257 / 267$ & $240 / 246$ & $208 / 222$ & $290 / 290$ & $253 / 259$ & $259 / 263$ & $164 / 164$ & $282 / 288$ & $198 / 204$ \\
\hline _7977_ & $127 / 127$ & $144 / 148$ & $270 / 270$ & $249 / 249$ & $242 / 246$ & $196 / 196$ & $290 / 290$ & $257 / 257$ & $261 / 263$ & $160 / 164$ & $282 / 288$ & $204 / 204$ \\
\hline -7985_ & $127 / 151$ & $138 / 138$ & $280 / 284$ & $249 / 271$ & $242 / 246$ & $204 / 222$ & $288 / 290$ & $249 / 257$ & $261 / 261$ & $164 / 164$ & $284 / 288$ & $204 / 204$ \\
\hline
\end{tabular}

\begin{tabular}{|c|c|c|c|c|c|c|c|c|c|c|c|}
\hline Animais & MCW257 & MCW264 & MCW282 & MCW288 & MCW290 & MCW291 & MCW293 & MCW310 & MCW314 & MCW320 & MCW324 \\
\hline -7716 & $286 / 294$ & $227 / 227$ & $284 / 284$ & $118 / 118$ & $196 / 196$ & $187 / 189$ & $220 / 220$ & $316 / 316$ & $274 / 278$ & $167 / 173$ & $277 / 283$ \\
\hline _7769_ & $286 / 294$ & $227 / 227$ & $284 / 302$ & $122 / 122$ & $196 / 196$ & $187 / 187$ & $220 / 226$ & $316 / 316$ & $274 / 278$ & $169 / 169$ & $277 / 283$ \\
\hline _ 7797 & $290 / 300$ & $231 / 235$ & $284 / 302$ & $122 / 122$ & $196 / 196$ & $187 / 187$ & $222 / 222$ & $318 / 318$ & $278 / 278$ & $167 / 177$ & $277 / 283$ \\
\hline -7822_ & $290 / 294$ & $231 / 239$ & $284 / 302$ & $116 / 116$ & $196 / 196$ & $187 / 187$ & $226 / 226$ & $316 / 316$ & $274 / 278$ & $167 / 173$ & $277 / 283$ \\
\hline 7975_ & $290 / 300$ & $231 / 239$ & $284 / 284$ & $116 / 116$ & $196 / 196$ & $185 / 189$ & $230 / 230$ & $316 / 316$ & $274 / 278$ & $169 / 173$ & $279 / 283$ \\
\hline _7977_ & $286 / 290$ & $235 / 239$ & $302 / 302$ & $114 / 118$ & $196 / 196$ & $187 / 187$ & $226 / 226$ & $314 / 318$ & $274 / 278$ & $167 / 171$ & $277 / 283$ \\
\hline 7985 & $288 / 290$ & $225 / 231$ & $290 / 302$ & $116 / 116$ & $196 / 196$ & $187 / 187$ & $226 / 226$ & $314 / 318$ & $274 / 278$ & $167 / 177$ & $277 / 283$ \\
\hline
\end{tabular}




\section{ANEXO B}

Tabela dos genótipos das fêmeas F1 para os marcadores microssatélites do cromossomo

2. As primeiras colunas correspondem à numeração dos animais.

\begin{tabular}{|c|c|c|c|c|c|c|c|c|c|c|c|c|}
\hline Animais & LEI0070 & LEI0086 & LEI0089 & LE10096 & LE10104 & LE10117 & LE10127 & LEI0141 & LEI0147 & LE10163 & LMU0013 & MCW009 \\
\hline-7805 & $201 / 201$ & $285 / 285$ & $192 / 194$ & $242 / 242$ & $219 / 219$ & $216 / 218$ & $215 / 215$ & $222 / 244$ & $263 / 267$ & $189 / 207$ & $272 / 272$ & $164 / 164$ \\
\hline${ }^{7761}$ & $187 / 197$ & $229 / 241$ & $194 / 194$ & $242 / 242$ & $219 / 223$ & $192 / 192$ & $215 / 215$ & $242 / 242$ & $267 / 271$ & $189 / 189$ & $272 / 272$ & $160 / 166$ \\
\hline 7743 & $201 / 201$ & $229 / 253$ & $194 / 198$ & $234 / 240$ & $219 / 223$ & $216 / 218$ & $215 / 247$ & $222 / 242$ & $271 / 271$ & $189 / 189$ & $268 / 278$ & $160 / 160$ \\
\hline _ 7972_ & $181 / 189$ & $251 / 251$ & $194 / 198$ & $234 / 240$ & $219 / 223$ & $194 / 194$ & $251 / 251$ & $222 / 242$ & $271 / 271$ & $189 / 207$ & $272 / 272$ & $162 / 168$ \\
\hline _7798_ & $217 / 217$ & $249 / 251$ & $180 / 194$ & $224 / 234$ & $219 / 223$ & $194 / 194$ & $225 / 243$ & $222 / 230$ & $267 / 267$ & $189 / 189$ & $272 / 272$ & $160 / 160$ \\
\hline 7749 & $193 / 197$ & $229 / 249$ & $196 / 198$ & $224 / 234$ & $219 / 223$ & $214 / 216$ & $225 / 225$ & $222 / 230$ & $267 / 267$ & $189 / 189$ & $272 / 272$ & $160 / 160$ \\
\hline _7722_ & $225 / 225$ & $249 / 275$ & $192 / 192$ & $224 / 224$ & $219 / 223$ & $194 / 212$ & $215 / 235$ & $228 / 228$ & $267 / 267$ & $189 / 207$ & $272 / 272$ & $168 / 168$ \\
\hline _7755 & $193 / 197$ & $229 / 229$ & $196 / 198$ & $224 / 224$ & $219 / 223$ & $194 / 194$ & $217 / 251$ & $230 / 230$ & $263 / 267$ & $189 / 207$ & $272 / 272$ & $160 / 160$ \\
\hline _7971_ & $215 / 217$ & $277 / 281$ & $194 / 194$ & $224 / 234$ & $219 / 223$ & $194 / 194$ & $215 / 225$ & $222 / 232$ & $271 / 271$ & $189 / 207$ & $272 / 278$ & $160 / 160$ \\
\hline -7980 & $195 / 221$ & $229 / 251$ & $178 / 198$ & $234 / 234$ & $219 / 219$ & $192 / 192$ & $215 / 215$ & $222 / 232$ & $261 / 263$ & $189 / 205$ & $272 / 272$ & $160 / 170$ \\
\hline . 7810 & $221 / 221$ & $229 / 229$ & $194 / 194$ & $224 / 234$ & $219 / 219$ & $194 / 194$ & $215 / 243$ & $228 / 228$ & $271 / 271$ & $189 / 205$ & $272 / 272$ & $160 / 166$ \\
\hline _7978_ & $181 / 193$ & $229 / 249$ & $198 / 198$ & $224 / 234$ & $219 / 223$ & $194 / 194$ & $227 / 239$ & $230 / 230$ & $267 / 267$ & $189 / 207$ & $272 / 272$ & $160 / 164$ \\
\hline _ 7709 & $225 / 225$ & $229 / 241$ & $194 / 194$ & $224 / 234$ & $219 / 223$ & $216 / 218$ & $215 / 215$ & $228 / 242$ & $263 / 267$ & $189 / 189$ & $272 / 272$ & $160 / 160$ \\
\hline 7816 & $215 / 217$ & $253 / 277$ & $180 / 194$ & $224 / 224$ & $219 / 223$ & $194 / 194$ & $225 / 225$ & $230 / 230$ & $271 / 271$ & $189 / 205$ & $272 / 272$ & $160 / 160$ \\
\hline _ 7713 & $217 / 221$ & $249 / 259$ & $180 / 194$ & $224 / 234$ & $235 / 235$ & $216 / 218$ & $215 / 215$ & $232 / 232$ & $263 / 263$ & $189 / 189$ & $272 / 272$ & $160 / 160$ \\
\hline _7987_ & $207 / 207$ & $229 / 229$ & $178 / 198$ & $226 / 235$ & $219 / 223$ & $196 / 196$ & $215 / 215$ & $222 / 230$ & $267 / 267$ & $189 / 189$ & $272 / 272$ & $160 / 170$ \\
\hline${ }_{-} 7771 \ldots$ & $207 / 207$ & $229 / 251$ & $194 / 198$ & $226 / 240$ & $219 / 219$ & $192 / 192$ & $215 / 215$ & $222 / 234$ & $261 / 271$ & $189 / 189$ & $272 / 272$ & $160 / 160$ \\
\hline _7765_ & $207 / 207$ & $229 / 253$ & $194 / 198$ & $230 / 240$ & $219 / 223$ & $192 / 192$ & $215 / 227$ & $228 / 228$ & $263 / 273$ & $189 / 205$ & $272 / 272$ & $160 / 160$ \\
\hline _ 7812 & $197 / 197$ & $251 / 253$ & $194 / 198$ & $224 / 240$ & $219 / 219$ & $194 / 194$ & $215 / 243$ & $228 / 228$ & $271 / 271$ & $189 / 207$ & $272 / 272$ & $162 / 162$ \\
\hline -7736_ & $197 / 197$ & $229 / 285$ & $180 / 194$ & $224 / 240$ & $219 / 219$ & $194 / 194$ & $215 / 243$ & $230 / 230$ & $261 / 261$ & $205 / 207$ & $272 / 272$ & $.160 / 160$ \\
\hline Animais & MCW027 & MCW063 & MCW087 & MCW173 & MCW184 & MCW185 & MCW205 & MCW220 & MCW234 & MCW239 & MCW245 & MCW247 \\
\hline 7805 & $125 / 137$ & $142 / 148$ & $276 / 276$ & $270 / 270$ & $243 / 243$ & $196 / 196$ & $286 / 290$ & $257 / 257$ & $263 / 263$ & $160 / 166$ & $288 / 288$ & $204 / 204$ \\
\hline${ }^{7761}$ & $153 / 153$ & $142 / 142$ & $280 / 282$ & $248 / 248$ & $243 / 247$ & $204 / 222$ & $282 / 288$ & $257 / 257$ & $261 / 261$ & $160 / 166$ & $288 / 288$ & $200 / 204$ \\
\hline _ 7743 & $133 / 137$ & $142 / 142$ & $274 / 280$ & $268 / 270$ & $241 / 243$ & $208 / 208$ & $290 / 290$ & $257 / 259$ & $263 / 263$ & $164 / 164$ & $282 / 288$ & $200 / 204$ \\
\hline - 7972 & $135 / 151$ & $136 / 136$ & $272 / 280$ & $270 / 270$ & $243 / 247$ & $202 / 222$ & $286 / 290$ & $253 / 259$ & $265 / 265$ & $160 / 164$ & $282 / 288$ & $204 / 210$ \\
\hline _7798_ & $121 / 135$ & $150 / 150$ & $280 / 284$ & $248 / 254$ & $243 / 247$ & $202 / 222$ & $288 / 290$ & $257 / 257$ & $263 / 263$ & $160 / 160$ & $282 / 288$ & $200 / 204$ \\
\hline _7749_ & $123 / 137$ & $134 / 142$ & $268 / 272$ & $270 / 270$ & $243 / 247$ & $210 / 210$ & $290 / 290$ & $257 / 257$ & $263 / 263$ & $160 / 164$ & $282 / 288$ & $204 / 204$ \\
\hline _ 7722_ & $123 / 139$ & $148 / 148$ & $276 / 276$ & $270 / 270$ & $241 / 243$ & $196 / 196$ & $286 / 286$ & $257 / 259$ & $263 / 263$ & $160 / 166$ & $288 / 288$ & $204 / 210$ \\
\hline _7755 & $119 / 145$ & $142 / 148$ & $288 / 288$ & $258 / 258$ & $243 / 247$ & $210 / 222$ & $286 / 290$ & $257 / 257$ & $271 / 271$ & $164 / 164$ & $282 / 288$ & $204 / 204$ \\
\hline _7971_ & $133 / 137$ & $142 / 146$ & $276 / 280$ & $270 / 270$ & $241 / 247$ & $208 / 222$ & $286 / 290$ & $253 / 259$ & $263 / 263$ & $160 / 164$ & $288 / 288$ & $200 / 204$ \\
\hline _7980_ & $123 / 153$ & $142 / 144$ & $274 / 280$ & $248 / 248$ & $243 / 247$ & $204 / 204$ & $290 / 290$ & $257 / 257$ & $261 / 261$ & $164 / 164$ & $282 / 288$ & $200 / 200$ \\
\hline-7810 & $123 / 137$ & $134 / 146$ & $284 / 284$ & $270 / 270$ & $241 / 241$ & $208 / 208$ & $286 / 288$ & $257 / 257$ & $263 / 263$ & $164 / 164$ & $288 / 288$ & $204 / 210$ \\
\hline${ }^{7978}$ & $131 / 131$ & $134 / 142$ & $268 / 278$ & $268 / 270$ & $243 / 247$ & $196 / 222$ & $286 / 290$ & $257 / 257$ & $263 / 267$ & $160 / 164$ & $282 / 288$ & $204 / 204$ \\
\hline -7709_ & $121 / 121$ & $142 / 152$ & $280 / 284$ & $248 / 248$ & $243 / 247$ & $202 / 222$ & $290 / 290$ & $257 / 257$ & $261 / 261$ & $166 / 166$ & $282 / 288$ & $200 / 204$ \\
\hline _7816 & $137 / 153$ & $148 / 152$ & $276 / 276$ & $248 / 248$ & $241 / 243$ & $202 / 222$ & $286 / 088$ & $257 / 257$ & $265 / 271$ & $164 / 164$ & $282 / 288$ & $204 / 210$ \\
\hline _7713 & $125 / 137$ & $134 / 148$ & $280 / 284$ & $248 / 248$ & $243 / 247$ & $196 / 196$ & $288 / 290$ & $257 / 257$ & $263 / 263$ & $160 / 166$ & $282 / 288$ & $200 / 204$ \\
\hline _ 7987 & $123 / 137$ & $138 / 138$ & $280 / 284$ & $248 / 248$ & $243 / 247$ & $204 / 204$ & $290 / 290$ & $257 / 257$ & $261 / 261$ & $164 / 164$ & $282 / 288$ & $204 / 204$ \\
\hline _ 7771 & $133 / 137$ & $142 / 142$ & $274 / 280$ & $268 / 268$ & $241 / 241$ & $196 / 196$ & $286 / 290$ & $257 / 257$ & $263 / 267$ & $166 / 166$ & $288 / 288$ & $204 / 204$ \\
\hline _ 7765 & $121 / 135$ & $134 / 152$ & $272 / 280$ & $268 / 268$ & $241 / 241$ & $196 / 222$ & $286 / 288$ & $257 / 257$ & $263 / 267$ & $166 / 166$ & $288 / 288$ & $204 / 210$ \\
\hline _7812 & $123 / 137$ & $148 / 152$ & $268 / 284$ & $268 / 270$ & $241 / 243$ & $208 / 208$ & $286 / 290$ & $257 / 257$ & $263 / 263$ & $164 / 164$ & $282 / 288$ & $204 / 204$ \\
\hline -7736_ & $123 / 123$ & $134 / 146$ & $276 / 276$ & $264 / 268$ & $243 / 247$ & $202 / 222$ & $286 / 288$ & $257 / 257$ & $263 / 263$ & $164 / 164$ & $282 / 288$ & $204 / 204$ \\
\hline
\end{tabular}




\begin{tabular}{|c|c|c|c|c|c|c|c|c|c|c|c|}
\hline Animais & MCW257 & MCW264 & MCW282 & MCW288 & MCW290 & MCW291 & MCW293 & MCW310 & MCW314 & MCW320 & MCW324 \\
\hline-7805 & $294 / 300$ & $241 / 241$ & $286 / 286$ & $116 / 116$ & $194 / 194$ & $185 / 189$ & $228 / 228$ & $316 / 316$ & $276 / 280$ & $167 / 173$ & $279 / 283$ \\
\hline _7761 & $288 / 290$ & $223 / 235$ & $292 / 304$ & $116 / 116$ & $196 / 196$ & $187 / 187$ & $220 / 224$ & $318 / 318$ & $276 / 280$ & $167 / 175$ & $277 / 283$ \\
\hline _7743_ & $290 / 294$ & $231 / 239$ & $286 / 292$ & $116 / 116$ & $196 / 196$ & $185 / 189$ & $220 / 228$ & $316 / 316$ & $276 / 280$ & $167 / 171$ & $277 / 283$ \\
\hline _7972_ & $290 / 294$ & $235 / 239$ & $286 / 292$ & $116 / 122$ & $196 / 196$ & $185 / 189$ & $220 / 228$ & $318 / 318$ & $276 / 280$ & $167 / 173$ & $279 / 283$ \\
\hline _7798_ & $290 / 300$ & $231 / 231$ & $290 / 290$ & $114 / 114$ & $196 / 196$ & $187 / 187$ & $222 / 222$ & $318 / 318$ & $276 / 280$ & $167 / 171$ & $279 / 285$ \\
\hline -7749 & $286 / 290$ & $225 / 239$ & $286 / 290$ & $118 / 122$ & $196 / 196$ & $187 / 187$ & $222 / 228$ & $318 / 318$ & $276 / 280$ & $167 / 177$ & $277 / 283$ \\
\hline _ 7722 & $294 / 300$ & $235 / 239$ & $286 / 286$ & $116 / 116$ & $194 / 194$ & $185 / 189$ & $224 / 224$ & $316 / 316$ & $276 / 280$ & $167 / 171$ & $277 / 283$ \\
\hline _ 7755 & $286 / 290$ & $235 / 239$ & $288 / 288$ & $114 / 118$ & $196 / 196$ & $187 / 187$ & $228 / 232$ & $318 / 318$ & $276 / 280$ & $167 / 171$ & $277 / 283$ \\
\hline _7971_ & $290 / 294$ & $231 / 239$ & $284 / 290$ & $118 / 122$ & $196 / 196$ & $185 / 189$ & $224 / 228$ & $316 / 316$ & $276 / 280$ & $167 / 173$ & $277 / 283$ \\
\hline 7980 & $286 / 290$ & $243 / 243$ & $284 / 298$ & $116 / 116$ & $194 / 194$ & $187 / 189$ & $222 / 228$ & $316 / 316$ & $276 / 280$ & $167 / 177$ & $283 / 283$ \\
\hline-7810 & $294 / 300$ & $241 / 243$ & $286 / 286$ & $116 / 116$ & $190 / 198$ & $185 / 189$ & $220 / 226$ & $318 / 318$ & $276 / 280$ & $167 / 177$ & $277 / 283$ \\
\hline _7978_ & $286 / 290$ & $235 / 239$ & $284 / 284$ & $116 / 116$ & $196 / 196$ & $187 / 187$ & $222 / 222$ & $318 / 318$ & $276 / 280$ & $167 / 173$ & $277 / 283$ \\
\hline 7709 & $288 / 290$ & $225 / 235$ & $286 / 286$ & $116 / 116$ & $196 / 196$ & $187 / 187$ & $222 / 222$ & $318 / 318$ & $276 / 280$ & $167 / 177$ & $277 / 283$ \\
\hline -7816 & $290 / 300$ & $235 / 239$ & $286 / 286$ & $120 / 122$ & $196 / 200$ & $187 / 187$ & $224 / 230$ & $318 / 318$ & $276 / 280$ & $167 / 171$ & $277 / 283$ \\
\hline _ 7713 & $288 / 300$ & $225 / 231$ & $286 / 286$ & $116 / 122$ & $194 / 194$ & $169 / 189$ & $220 / 224$ & $318 / 318$ & $276 / 280$ & $167 / 177$ & $277 / 283$ \\
\hline _ 7987 & $288 / 290$ & $225 / 231$ & $284 / 284$ & $118 / 118$ & $196 / 196$ & $187 / 187$ & $224 / 228$ & $316 / 316$ & $276 / 280$ & $167 / 177$ & $283 / 283$ \\
\hline _7771_ & $290 / 294$ & $225 / 231$ & $284 / 284$ & $116 / 122$ & $196 / 196$ & $187 / 187$ & $228 / 228$ & $316 / 316$ & $276 / 280$ & $167 / 171$ & $227 / 283$ \\
\hline _ 7765 & $286 / 294$ & $231 / 231$ & $286 / 304$ & $120 / 120$ & $194 / 194$ & $187 / 187$ & $226 / 230$ & $316 / 316$ & $276 / 280$ & $167 / 167$ & $277 / 283$ \\
\hline _ 7812 & $294 / 300$ & $235 / 239$ & $286 / 304$ & $114 / 122$ & $196 / 196$ & $185 / 189$ & $220 / 220$ & $318 / 318$ & $276 / 280$ & $167 / 177$ & $277 / 283$ \\
\hline _ 7736 & $294 / 300$ & $243 / 243$ & $286 / 304$ & $116 / 116$ & $196 / 200$ & $187 / 187$ & $222 / 230$ & $318 / 318$ & $276 / 280$ & $167 / 177$ & $277 / 283$ \\
\hline
\end{tabular}




\section{ANEXO C}

Tabela dos genótipos dos machos F1 para os marcadores microssatélites do cromossomo 4. As primeiras colunas correspondem à numeração dos animais.

\begin{tabular}{|c|c|c|c|c|c|c|c|c|c|}
\hline Animais & LE1062 & LEI063 & LEI073 & LEI076 & LEI081 & LEI085 & LEI094 & LEI100 & LEI1 22 \\
\hline 7716 & $85 / 109$ & $206 / 266$ & $195 / 195$ & $252 / 252$ & $246 / 246$ & $265 / 265$ & $261 / 271$ & $274 / 274$ & $287 / 299$ \\
\hline 7769 & $99 / 109$ & $208 / 254$ & $173 / 173$ & $266 / 266$ & $218 / 218$ & $257 / 263$ & $271 / 271$ & $274 / 274$ & $287 / 299$ \\
\hline 7797 & $79 / 109$ & $208 / 208$ & $161 / 191$ & $256 / 256$ & $238 / 238$ & $261 / 263$ & $261 / 271$ & $264 / 276$ & $297 / 297$ \\
\hline 7822 & $79 / 85$ & $208 / 208$ & $185 / 185$ & $262 / 268$ & $234 / 234$ & $261 / 263$ & $271 / 275$ & $274 / 274$ & $? / ?$ \\
\hline 7975 & $85 / 85$ & $208 / 208$ & $167 / 167$ & $268 / 268$ & $234 / 234$ & $267 / 273$ & $261 / 273$ & $274 / 274$ & $287 / 299$ \\
\hline 7977 & $79 / 99$ & $266 / 266$ & $187 / 201$ & $256 / 266$ & $216 / 250$ & $257 / 263$ & $263 / 283$ & $266 / 268$ & $297 / 297$ \\
\hline -7985 & $79 / 107$ & $206 / 206$ & $185 / 193$ & $268 / 268$ & $234 / 234$ & $261 / 263$ & $263 / 271$ & $274 / 276$ & $295 / 295$ \\
\hline
\end{tabular}

\begin{tabular}{|c|c|c|c|c|c|c|c|c|c|}
\hline Animais & LEI144 & MCW99 & MCW122 & MCW174 & MCW240 & MCW251 & MCW284 & MCW295 & MCW308 \\
\hline 7716 & $265 / 265$ & $279 / 279$ & $269 / 269$ & $274 / 278$ & $171 / 171$ & $177 / 177$ & $? / ?$ & $98 / 102$ & $205 / 205$ \\
\hline _7769_ & $265 / 265$ & $277 / 277$ & $267 / 267$ & $262 / 264$ & $189 / 193$ & $177 / 177$ & $236 / 242$ & $98 / 98$ & $203 / 203$ \\
\hline _ 7797 & $265 / 265$ & $279 / 281$ & $269 / 269$ & $262 / 274$ & $191 / 193$ & $177 / 177$ & $236 / 242$ & $92 / 102$ & $205 / 205$ \\
\hline _ 7822 & $265 / 271$ & $277 / 277$ & $267 / 267$ & $262 / 272$ & $181 / 191$ & $175 / 175$ & $242 / 248$ & $92 / 98$ & $203 / 205$ \\
\hline _ 7975 & $265 / 265$ & $277 / 277$ & $273 / 277$ & $262 / 278$ & $171 / 191$ & $175 / 175$ & $236 / 236$ & $98 / 104$ & $203 / 203$ \\
\hline _.7977_ & $265 / 265$ & $279 / 279$ & $267 / 271$ & $262 / 278$ & $171 / 193$ & $175 / 175$ & $236 / 242$ & $98 / 102$ & $203 / 203$ \\
\hline _.7985_ & $263 / 267$ & $279 / 279$ & $267 / 271$ & $274 / 278$ & $171 / 193$ & $177 / 177$ & $236 / 242$ & $98 / 102$ & $205 / 205$ \\
\hline
\end{tabular}




\section{ANEXO D}

Tabela dos genótipos das fêmeas F1 para os marcadores microssatélites do cromossomo 4. As primeiras colunas correspondem à numeração dos animais.

\begin{tabular}{|c|c|c|c|c|c|c|c|c|c|}
\hline Animais & LEI062 & LEI063 & LE1073 & LEI076 & LEO081 & LEI085 & LEI094 & LEI100 & LEI122 \\
\hline-7805 & $109 / 109$ & $208 / 208$ & $185 / 193$ & $250 / 250$ & $218 / 218$ & $261 / 263$ & $281 / 281$ & $274 / 274$ & $299 / 301$ \\
\hline _7761_ & $85 / 109$ & $206 / 206$ & $159 / 159$ & $264 / 268$ & $234 / 240$ & $261 / 263$ & $259 / 271$ & $262 / 266$ & $295 / 295$ \\
\hline -7743_ & $79 / 85$ & $208 / 208$ & $167 / 167$ & $252 / 280$ & $216 / 254$ & $263 / 263$ & $271 / 283$ & $274 / 276$ & $287 / 299$ \\
\hline 7972 & $85 / 109$ & $206 / 206$ & $167 / 167$ & $268 / 268$ & $234 / 234$ & $263 / 263$ & $261 / 263$ & $274 / 274$ & $297 / 297$ \\
\hline -7798 & $109 / 109$ & $206 / 206$ & $193 / 193$ & $266 / 266$ & $238 / 240$ & $261 / 263$ & $261 / 263$ & $266 / 276$ & $295 / 295$ \\
\hline 7749 & $109 / 113$ & $208 / 208$ & $159 / 159$ & $266 / 268$ & $234 / 234$ & $265 / 271$ & $271 / 271$ & $274 / 274$ & $305 / 305$ \\
\hline 7722 & $109 / 109$ & $206 / 206$ & $185 / 193$ & $266 / 266$ & $218 / 238$ & $257 / 259$ & $261 / 271$ & $274 / 274$ & $285 / 297$ \\
\hline -7755 & $85 / 99$ & $208 / 208$ & $159 / 159$ & $264 / 268$ & $234 / 234$ & $257 / 263$ & $271 / 271$ & $274 / 274$ & $297 / 297$ \\
\hline _ 7971 & $79 / 85$ & $208 / 208$ & $167 / 167$ & $250 / 250$ & $254 / 254$ & $263 / 263$ & $271 / 283$ & $276 / 276$ & $287 / 299$ \\
\hline 7980 & $109 / 109$ & $206 / 206$ & $159 / 159$ & $264 / 268$ & $234 / 234$ & $261 / 263$ & $279 / 279$ & $274 / 276$ & $295 / 295$ \\
\hline-7810 & $85 / 109$ & $274 / 274$ & $167 / 167$ & $250 / 268$ & $234 / 234$ & $263 / 263$ & $281 / 281$ & $272 / 276$ & $295 / 295$ \\
\hline 7978 & $79 / 85$ & $206 / 206$ & $159 / 159$ & $266 / 266$ & $234 / 250$ & $255 / 255$ & $271 / 283$ & $274 / 274$ & $289 / 289$ \\
\hline 7709 & $79 / 85$ & $206 / 206$ & $187 / 193$ & $268 / 268$ & $234 / 240$ & $261 / 273$ & $271 / 271$ & $274 / 276$ & $287 / 295$ \\
\hline _7816 & $85 / 85$ & $206 / 206$ & $167 / 167$ & $250 / 268$ & $234 / 234$ & $273 / 273$ & $261 / 271$ & $274 / 274$ & $297 / 303$ \\
\hline _ $7713 \ldots$ & $85 / 85$ & $208 / 214$ & $193 / 193$ & $268 / 268$ & $234 / 240$ & $263 / 263$ & $263 / 267$ & $274 / 276$ & $295 / 295$ \\
\hline _ 7987 & $105 / 105$ & $208 / 208$ & $159 / 159$ & $264 / 268$ & $234 / 240$ & $261 / 263$ & $249 / 255$ & $274 / 276$ & $295 / 299$ \\
\hline _7771_ & $85 / 109$ & $208 / 208$ & $159 / 159$ & $250 / 268$ & $234 / 234$ & $261 / 263$ & $271 / 283$ & $274 / 274$ & $287 / 299$ \\
\hline _ 7765 & $85 / 99$ & $208 / 208$ & $159 / 159$ & $266 / 280$ & $218 / 218$ & $257 / 263$ & $261 / 263$ & $264 / 266$ & $297 / 297$ \\
\hline -7812 & $85 / 109$ & $208 / 208$ & $159 / 167$ & $250 / 268$ & $226 / 244$ & $261 / 263$ & $279 / 279$ & $270 / 276$ & $287 / 287$ \\
\hline _-7736 & $79 / 109$ & $274 / 274$ & $167 / 167$ & $250 / 268$ & $226 / 246$ & $261 / 263$ & $261 / 271$ & $276 / 276$ & $287 / 287$ \\
\hline
\end{tabular}

\begin{tabular}{|c|c|c|c|c|c|c|c|c|c|}
\hline Animais & LEI144 & MCW99 & MCIV122 & MCW174 & MCW240 & MCW251 & MCW284 & MCW295 & MCW308 \\
\hline _7805 & $261 / 261$ & $277 / 279$ & $267 / 267$ & $266 / 274$ & $171 / 171$ & $177 / 177$ & $236 / 236$ & $98 / 102$ & $201 / 205$ \\
\hline _7761 & $265 / 265$ & $279 / 279$ & $267 / 267$ & $274 / 274$ & $189 / 189$ & $175 / 175$ & $236 / 236$ & $98 / 102$ & $205 / 205$ \\
\hline _ 7743 & $271 / 271$ & $279 / 279$ & $269 / 269$ & $278 / 280$ & $173 / 189$ & $177 / 177$ & $236 / 242$ & $98 / 102$ & $205 / 205$ \\
\hline _ 7972 & $265 / 273$ & $279 / 279$ & $269 / 273$ & $274 / 278$ & $171 / 191$ & $177 / 177$ & $236 / 236$ & $108 / 108$ & $205 / 205$ \\
\hline 7798 & $271 / 271$ & $279 / 279$ & $267 / 267$ & $262 / 278$ & $191 / 191$ & $177 / 177$ & $236 / 242$ & $98 / 102$ & $203 / 203$ \\
\hline _7749_ & $259 / 267$ & $279 / 279$ & $267 / 267$ & $274 / 278$ & $171 / 193$ & $175 / 175$ & $238 / 242$ & $98 / 102$ & $203 / 203$ \\
\hline _ 7722 & $257 / 259$ & $277 / 279$ & $269 / 269$ & $266 / 274$ & $171 / 171$ & $177 / 177$ & $236 / 236$ & $90 / 102$ & $203 / 203$ \\
\hline -7755_ & $271 / 271$ & $279 / 279$ & $267 / 271$ & $266 / 280$ & $171 / 193$ & $175 / 175$ & $236 / 236$ & $98 / 102$ & $203 / 203$ \\
\hline _7971_ & $259 / 271$ & $277 / 277$ & $269 / 269$ & $274 / 280$ & $193 / 189$ & $177 / 177$ & $236 / 242$ & $90 / 98$ & $203 / 205$ \\
\hline -7980_ & $263 / 269$ & $277 / 277$ & $267 / 267$ & $262 / 278$ & $179 / 189$ & $177 / 177$ & $236 / 242$ & $90 / 102$ & $205 / 205$ \\
\hline 7810 & $265 / 265$ & $279 / 279$ & $267 / 267$ & $262 / 278$ & $173 / 185$ & $177 / 177$ & $236 / 236$ & $98 / 102$ & $205 / 205$ \\
\hline _ 7978 & $265 / 271$ & $279 / 279$ & $267 / 267$ & $266 / 280$ & $171 / 181$ & $175 / 175$ & $238 / 242$ & $92 / 102$ & $205 / 205$ \\
\hline _7709_ & $265 / 279$ & $277 / 277$ & $267 / 273$ & $262 / 274$ & $189 / 191$ & $177 / 177$ & $236 / 242$ & $92 / 92$ & $205 / 205$ \\
\hline _7816 & $263 / 263$ & $279 / 279$ & $271 / 275$ & $262 / 278$ & $171 / 185$ & $177 / 177$ & $236 / 236$ & $96 / 110$ & $201 / 201$ \\
\hline _7713 & $271 / 271$ & $279 / 281$ & $267 / 271$ & $266 / 274$ & $183 / 189$ & $175 / 175$ & $238 / 242$ & $92 / 102$ & $205 / 205$ \\
\hline _ 7987 & $265 / 265$ & $277 / 277$ & $263 / 275$ & $262 / 274$ & $179 / 189$ & $177 / 177$ & $236 / 242$ & $92 / 112$ & $205 / 205$ \\
\hline _ 7771 & $265 / 267$ & $279 / 299$ & $267 / 267$ & $262 / 266$ & $181 / 191$ & $175 / 175$ & $236 / 236$ & $90 / 98$ & $203 / 203$ \\
\hline _ $7765_{-}$ & $279 / 279$ & $277 / 277$ & $267 / 267$ & $262 / 264$ & $171 / 193$ & $177 / 177$ & $236 / 236$ & $104 / 104$ & $203 / 203$ \\
\hline _7812_ & $259 / 269$ & $299 / 301$ & $269 / 269$ & $262 / 274$ & $173 / 173$ & $177 / 177$ & $236 / 236$ & $92 / 96$ & $205 / 205$ \\
\hline _ 7736 & $265 / 279$ & $277 / 277$ & $267 / 267$ & $262 / 262$ & $173 / 173$ & $177 / 177$ & $236 / 236$ & $92 / 98$ & $203 / 203$ \\
\hline
\end{tabular}




\section{ANEXO E}

Relação dos 5\% (machos e fêmeas) mais leves aos 42 dias de idade, e dos $5 \%$ mais pesados, representando $10 \%$ da população organizados nas placas. Animais leves possuem o código "0" (zero) e animais pesados possuem o código "1" (um) na coluna L/P. Cada bloco nas colunas "well" e "animal" representam uma família que teve seus animais amostrados. Como pode ser observado temos repetição de alguns parentais nas duas placas, o que possibilita a confirmação do genótipo encontrado e garantindo que as corridas podem ser equiparadas, ou seja, que os alelos encontrados em uma e outra placa, apesar de terem passado por eletroforeses diferentes, são os mesmos.

\begin{tabular}{|c|c|c|c|c|c|c|c|}
\hline $\begin{array}{l}\text { Placa } 01 \\
\text { Parentais }\end{array}$ & Well & Animal & $\mathrm{L} / \mathrm{P}$ & $\begin{array}{c}\text { Placa } 02 \\
\text { Parentais }\end{array}$ & Well & Animal & $\mathbf{L} / \mathbf{P}$ \\
\hline & A01 & 6037 & & & A01 & 5561 & \\
\hline & A02 & 241 & & & A02 & 88 & \\
\hline & A03 & 5596 & & & A03 & 6232 & \\
\hline & A04 & 5 & & & A04 & 332 & \\
\hline & A05 & 5561 & & & A05 & 6037 & \\
\hline & A06 & 570 & & & A06 & 241 & \\
\hline & A07 & 5921 & & & A07 & 5596 & \\
\hline & A08 & 37 & & & A08 & 5 & \\
\hline & A09 & 6232 & & & A09 & 5649 & \\
\hline & A10 & 332 & & & A10 & 886 & \\
\hline & A11 & 5661 & & & & & \\
\hline & A12 & 88 & & & A11 & 821 & 0 \\
\hline 6232 & & & & 5661 & A 12 & 827 & 0 \\
\hline 332 & B01 & 2691 & 1 & 88 & B01 & 1233 & 1 \\
\hline 5661 & B02 & 2801 & 0 & & B02 & 1236 & 0 \\
\hline 88 & & & & & B03 & 1642 & 1 \\
\hline & B03 & 2066 & 0 & 6037 & B04 & 1975 & 1 \\
\hline 5561 & B04 & 2401 & 1 & 241 & B05 & 2479 & 1 \\
\hline 570 & B05 & 704 & 1 & & B06 & 2480 & 0 \\
\hline & B06 & 939 & 1 & & & & \\
\hline 5921 & B07 & 1140 & 0 & & B07 & 1244 & 1 \\
\hline 37 & B08 & 1352 & 0 & 5661 & B08 & 1460 & 1 \\
\hline & B09 & 1355 & 0 & 88 & B09 & 1462 & 1 \\
\hline & B10 & 1357 & 1 & & $\mathrm{~B} 10$ & 1466 & 0 \\
\hline & B11 & 1548 & 0 & & B11 & 2149 & 1 \\
\hline & B12 & 1716 & 1 & 6232 & $\mathrm{~B} 12$ & 2319 & 0 \\
\hline & & & & 332 & $\mathrm{C} 01$ & 2321 & 0 \\
\hline & C01 & 951 & 0 & & $\mathrm{C} 02$ & 2639 & 0 \\
\hline 5561 & $\mathrm{CO2}$ & 1376 & 1 & & & & \\
\hline 570 & $\mathrm{CO3}$ & 1378 & 1 & & $\mathrm{C} 03$ & 893 & 0 \\
\hline
\end{tabular}




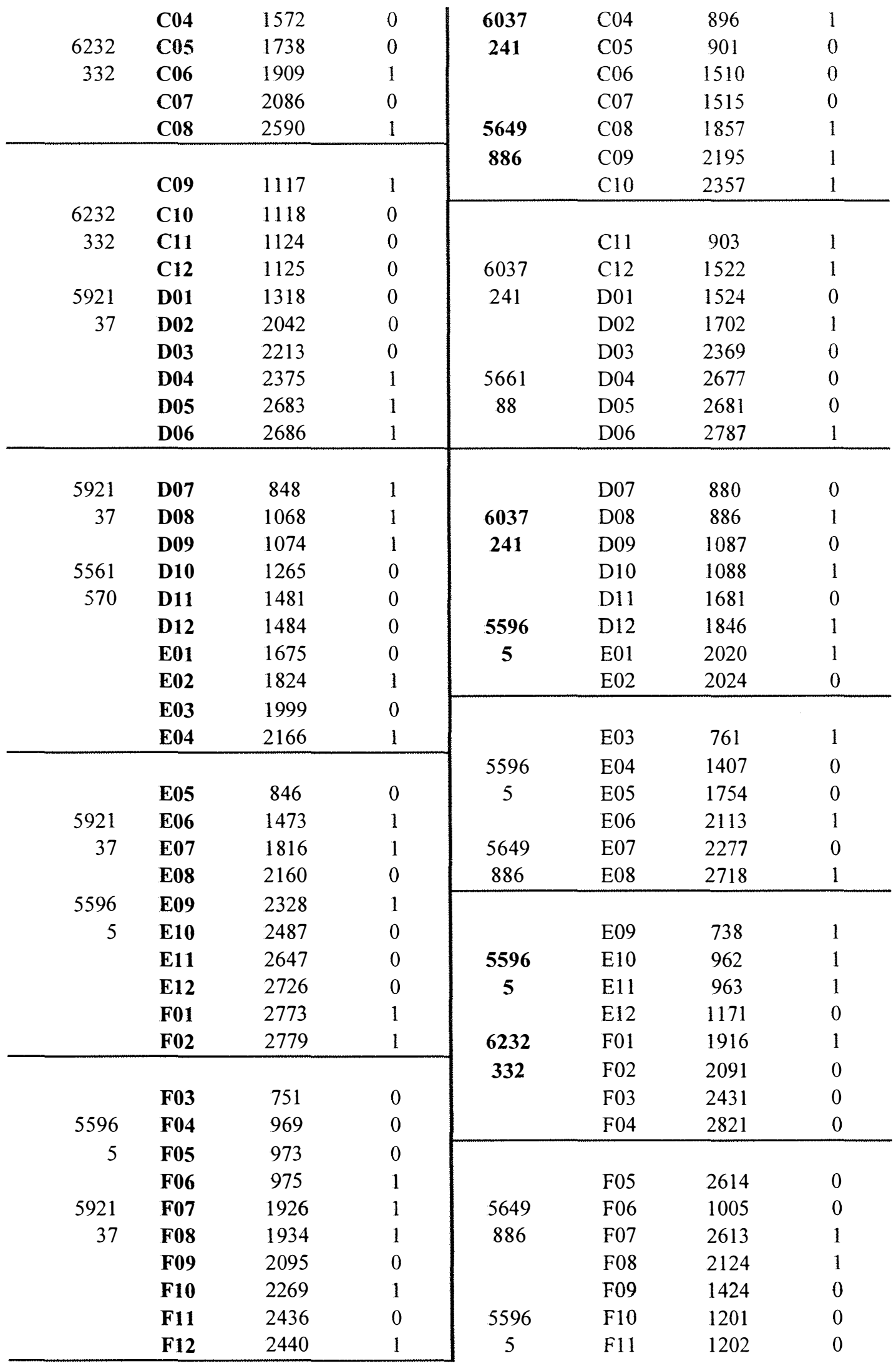




\begin{tabular}{|c|c|c|c|c|c|c|c|}
\hline 6232 & $\begin{array}{l}\text { G01 } \\
\text { G02 }\end{array}$ & $\begin{array}{c}932 \\
1344\end{array}$ & $\begin{array}{l}1 \\
1\end{array}$ & & $\begin{array}{l}\text { F12 } \\
\text { G01 } \\
\text { G02 }\end{array}$ & $\begin{array}{l}2293 \\
1421 \\
1200\end{array}$ & $\begin{array}{l}1 \\
1 \\
1\end{array}$ \\
\hline \multirow{2}{*}{332} & G03 & 1539 & 1 & \multirow{6}{*}{$\begin{array}{c}5649 \\
886\end{array}$} & & & \\
\hline & G04 & 2060 & 1 & & G03 & 1623 & 0 \\
\hline 5561 & G05 & 2396 & 0 & & G04 & 1785 & 1 \\
\hline \multirow[t]{5}{*}{570} & G06 & 2551 & 0 & & G05 & 1960 & 0 \\
\hline & G07 & 2553 & 0 & & G06 & 2300 & 0 \\
\hline & G08 & 2704 & 0 & & G07 & 2301 & 0 \\
\hline & & & & \multirow{3}{*}{$\begin{array}{c}6232 \\
332\end{array}$} & G08 & 2463 & 1 \\
\hline & G09 & 810 & 0 & & G09 & 2929 & 1 \\
\hline 5661 & G10 & 1218 & 0 & & G10 & 2931 & 1 \\
\hline \multirow[t]{2}{*}{88} & G11 & 1444 & 0 & \multirow{7}{*}{$\begin{array}{c}5649 \\
886\end{array}$} & & & \\
\hline & G12 & 1633 & 1 & & G11 & 990 & 0 \\
\hline 5561 & H01 & 1968 & 0 & & G12 & 1191 & 0 \\
\hline \multirow[t]{5}{*}{570} & H02 & 2133 & 1 & & H01 & 1195 & 1 \\
\hline & H03 & 2138 & 1 & & H02 & 1611 & 0 \\
\hline & H04 & 2477 & 1 & & $\mathrm{H} 03$ & 1615 & 1 \\
\hline & & & & & H04 & 1773 & 1 \\
\hline & H05 & 1494 & 0 & \multirow{4}{*}{$\begin{array}{c}6037 \\
241\end{array}$} & H05 & 1948 & 1 \\
\hline 5921 & H06 & 1830 & 0 & & H06 & 2117 & 1 \\
\hline \multirow[t]{2}{*}{37} & H07 & 2008 & 1 & & $\mathrm{H} 07$ & 2604 & 0 \\
\hline & H08 & 2343 & 1 & & H08 & 2768 & 0 \\
\hline \multirow{5}{*}{$\begin{array}{r}6037 \\
241\end{array}$} & H09 & 2348 & 1 & & & & \\
\hline & H10 & 2505 & 0 & 6232 & H09 & 924 & 1 \\
\hline & H11 & 2507 & 0 & 332 & $\mathrm{H} 10$ & 2386 & 1 \\
\hline & H12 & 2661 & 1 & 5661 & $\mathrm{H} 11$ & 2549 & 0 \\
\hline & & & & 88 & $\mathrm{H} 12$ & 2550 & 0 \\
\hline
\end{tabular}




\section{ANEXO F}

Tabela apresentando os marcadores microssatélites para o cromossomo 2 com suas respectivas posições em $\mathrm{cM}$, tamanho em pares de bases, marcação fluorescente e número de alelos utilizados na genotipagem seletiva.

\begin{tabular}{ccccc}
\hline $\begin{array}{c}\text { Marcadores } \\
\text { CROMOSSOMO 2 }\end{array}$ & Posição (cM) & Tamanho(pb) & Cor & n.alelos \\
\hline LEI0163 & 3 & $189-207$ & FAM & 3 \\
MCW205 & 5 & $282-290$ & HEX & 4 \\
MCW0082 & 30 & $100-118$ & HEX & 3 \\
LMU0013 & 65 & $270-280$ & FAM & 4 \\
LEI0117 & 70 & $192-217$ & FAM & 4 \\
MCW0063 & 119 & $134-153$ & HEX & 6 \\
MCW0239 & 135 & $258-170$ & FAM & 5 \\
LEI0089 & 165 & $180-189$ & HEX & 5 \\
MCW0293 & 182 & $224-232$ & TET & 3 \\
ADL373 & 215 & $166-168$ & FAM & - \\
LEI0096 & 233 & $228-246$ & FAM & 7 \\
MCW0291 & 246 & $183-191$ & TET & 4 \\
MCW0009 & 261 & $162-174$ & FAM & 3 \\
LEI0147 & 282 & $263-273$ & HEX & 4 \\
MCW0185 & 304 & $200-226$ & TET & 3 \\
MCW0234 & 315 & $262-269$ & TET & 3 \\
MCW0264 & 320 & $227-241$ & HEX & 5 \\
GCT02 & 349 & $\sim 156$ & HEX & - \\
MCW0245 & 364 & $284-290$ & FAM & 2 \\
MCW0314 & 375 & $278-284$ & TET & 2 \\
LEI0070 & 379 & $185-223$ & HEX & 6 \\
MCW0320 & 392 & $169-177$ & FAM & 4 \\
MCW0324 & 412 & $279-285$ & TET & 3 \\
MCW157 & 474 & $291-301$ & HEX & 3 \\
\hline
\end{tabular}




\section{ANEXO G}

Tabela apresentando os marcadores microssatélites para o cromossomo 4 com suas respectivas posições em $\mathrm{cM}$, tamanho em pares de bases, marcação fluorescente e número de alelos utilizados na genotipagem seletiva.

\begin{tabular}{ccccc}
\hline $\begin{array}{c}\text { Marcadores } \\
\text { CROMOSSOMO 4 }\end{array}$ & Tam(pb) & Cor & n.alelos & Pos.(cM) \\
\hline MCW0295 & $94-108$ & HEX & 5 & 75 \\
MCW0251 & $175-177$ & TET & 2 & 87 \\
LEI0100 & $242-274$ & FAM & 2 & 98 \\
LEI0122 & $289-301$ & HEX & 6 & 132 \\
LEI0144 & $261-275$ & TET & 4 & 152 \\
LEI0076 & $254-280$ & HEX & 5 & 182 \\
LEI0081 & $218-260$ & TET & 5 & 188 \\
MCW0240 & $172-197$ & FAM & 8 & 205 \\
LEI0063 & $206-290$ & HEX & 7 & 227 \\
LEI0085 & $259-273$ & HEX & 5 & 231 \\
LEI0062 & $81-113$ & FAM & 7 & 239 \\
MCW0174 & $261-278$ & HEX & 7 & 252 \\
\hline
\end{tabular}




\section{REFERÊNCIAS BIBLIOGRÁFICAS}

ALLY, A.H.; CHOMCZYNSKI, P. DNAzol TM reagent for rapid and efficient purification of genomic DNA. Focus, v.17, p.70-71, 1997.

ARÚS, P.; MORENO-GONZÁLEZ, J. Marker-assisted selection. In: HAYWARD, M.D.; BOSEMARK, N.O.; ROMAGOSA, I. Plant Breeding: principles and prospects. London: Chapman \& Hall, 1993. Cap.19, p.314-331.

BARON, E.E; RUY, D.C.; NONES, K.; LEDUR, M.C.; ZANELLA, E.L.; COUTINHO, L.L. Avaliação de marcadores microssatélites para mapeamento de QTLs nos cromossomos 1, 2, 3, 4 e 5 de aves. In: REUNIÃO DA SOCIEDADE BRASILEIRA DE GENÉTICA, 47., Águas de Lindóia, 2001. Poster/ Resumos. Águas de Lindóia: SBG, 2001.

BECKMANN, J.S.; SOLER, M. Detection of linkage between marker loci and loci affecting quantitative traits in crosses between segregating populations. Theoretical and Applied Genetics, v. 6, p.228-236, 1988.

BOTSTEIN, D.; WHITE, R.L.; SKOLNICK, M.; DAVIS, R.W. Construction of a genetic map in man using restriction fragment length polymorphisms. American Journal of Humam Genetics, v.32, p.314-331, 1980. 
BOVENHUIS, H.; SPELMAN, R.J. Selective genotyping to detect quantitative trait loci for multiple traits in outbred populations. Journal of Dairy Science, v.83, p.173-180, 2000.

BOVENHUIS, H.; VAN AENDONK, J.A.M.; DAVIS, G.; ELSEN, J.M.; HALEY, C.S.; HILL, W.G.; BARET, P.V.; HETZEL, D.J.S.; NICHOLAS, F.W. Detection and mapping of quantitative trait loci in farm animals. Livestock Production Science, v.52, p.135-144, 1997.

BUMSTEAD, N.; PALYGA, J. A preliminary linkage map of the chicken genome. Genomics, v.13, p.690-697, 1992.

CERVUS, versão 2.0, (Copyright Tristan Marshall 1998-2000)

(http://helios.bto.ed.ac.uk/evolgen/cervus/cervus.html) (31 may 2003)

CHENG, H.H. Mapping the chicken genome. Poultry Science, v.76, p.1101-1107, 1997.

CHENG, H.H.; CRITTENDEN, L.B. Microssatelite markers for genetic mapping in chicken. Poultry Science, v.73, p.539-546, 1994.

CHENG, H.H.; LEVIN, I.; VALlEJO, R.L.; KHATIB, H.; DODGSON, J.B.; CRITTENDEN, L.B.; HILLEL, J. Development of a genetic map of the chicken with markers of high utility. Poultry Science, v.74, p.1855-1874, 1995.

CHURCHILL, G. A. ; DOERGE, R. W. Emperical thresold values for quantitative trait mapping. Genetics, v.138, p.963-971, 1994. 
CRITTENDEN, L.B.; PROVENCHER, L.S.; LEVIN, I.; ABPLANALP, H.; BRILES, R.W.; BRILES, W.E.; DODGSON, J.B. Characterization of a red jungle fowl by white leghorn backcross reference population for molecular mapping of the chicken genome. Poultry Science, v.72, p.334-348, 1993.

CROOIJMANS, R. Gene hunting: molecular analysis of the chicken genome. Wageningen, 2000. 150p Dissertation (D.) - Wageningen University.

CROOIJMANS, R.P.M.A.; VAN KAMPEN, A.J.A.; VAN DER POEL, J.J.; GROENEN, M.A.M. High polymorphic microsatellite markers in poultry. Animal Genetics, v.34, p.410-413, 1993.

CROOIJMANS, R.P.M.A.; VAN KAMPEN, A.J.A.; VAN DER POEL, J.J.; GROENEN, M.A.M. New microsatellite markers on the linkage map of the chicken genome. Journal of Heredity, v.85, p.410-413, 1994.

CROOIJMANS, R.P.M.A.; VAN OERS, P.A.M.; STRIJK, J.A.; VAN DER POEL, J.J.; GROENEN, M.A.M. Preliminary linkage map of the chicken (Gallus domesticus) genome based on microsatellite markers: 77 new markers mapped. Poultry Science, v.75, p.746-754, 1996.

CROOIJMANS, R.P.M.A.; DIJKHOF, R.J.M.; VAN DER POEL, J.J.; GROENEN, M.A.M. New microsatellite markers in chicken optimized for automated fluorescent genotyping. Animal Genetics, v.28, p.427-437, 1997.

DARVASI, S.; SOLLER, M. Selective genotyping for determination of linkage between a marker locus and a quatitative trait locus. Theoretical and applied genetics, v.85, p.353-359, 1992. 
DE KONING, D. J.; JANSS, L. L. G.; RATTINK, A. P.; VAN OERS, P. A. M.; DE VRIES, B. J.; GROENEN, M. A. M.; VAN DER POEL, J. J.; DE GROOT, P. N.; BRASCAMP, E. W.; VAN ARENDONK, J. A. M. Detection of quantitative trait loci for backfat thickness and intramuscular fat content in Pigs (Sus scrofa). Genetics, v.152, p.1679-1690, 1999.

DE KONING, D. J.; RATTINK, A. P.; HARLIZIUS, B.; VAN AREDONK, J. A. M.; BRASCAMP, E. W.; GROENEN, M. A. M. Genome-wide scan for body composition reveals important role of imprinting. Proceedings of the National Academy of Sciences USA, v. 14, p.7947-7950, 2000.

DE KONING, D. J.; RATTINK, A. P.; HARLIZIUS, B; GROENEN, M. A. M.; BRASCAMP, E. W.; VAN ARENDONK, J. A. M. Detection and characterization of quantitative trait loci for growth and reproduction traits in pigs. Livestock Production Science, v.72, p.185-198, 2001.

DE KONING, D. J.; WINDSOR, D.; HOCKING, P. M.; BURT, D. W.; LAW, A.; HALEY, C. S.; MORRIS, A.; VINCENT, J.; GRIFFIN, H. Quantitative trait locus detection in commercial broiler lines using candidate regions. Journal of Animal Science v. 81, p. 1158-1165, 2003.

DODGSON, J.B.; CHENG, H.H.; OKIMOTO, R. DNA marker technology: A revolution in animal genetics. Poultry Science, v.76, p.1108-1114, 1997.

EMPRESA BRASILEIRA DE PESQUISA AGROPECUÁRIA . Artigos/2003 http://www.cnpsa.embrapa.br/ (17 jun 2004).

FALCONER, D.S.; MACKAY, T.F.C. Introduction to quantitative genetics. 4.ed. London: Prentice Hall, 1996. 464p. 
FERREIRA, M.E.; GRATTAPAGLIA, D. Introdução ao uso de marcadores moleculares em análise genética. 2.ed. Brasília: Embrapa, CENARGEN, 1996. 220 p.

GREEN, P.; FALLS, K.; CROOKS, S. Programa CRI-MAP VERSION 2.4. St. Louis: Washington University School of Medicine, 1990.

GROENEN, M.A.M.; CROOIJMANS, R.P.M.A.; VEENENDAL, T.; VAN KAAM, J.B.C.H.M.; VEREIJKEN, A.L.J.; VAN ARENDONK, J.A.M.; VAN DER POEL, J.J. QTL mapping in chicken using a three generation full sib family structure of an extreme broiler $x$ broiler cross. Animal Biotechnology, v.8, p.41-46, 1997.

GROENEN, M.A.M.; CROOIJMANS, R.P.M.A.; VEENENDAAL, A.; CHENG, H.H.; SIWEK, M.; VAN DER POEL, J.J. A comprehensive microsatellite linkage map of the chicken genome. Genomics, v.49, p.265-274, 1998.

GROENEN, M.A.M.; CHENG, H.H.; BUMSTEAD, N.; BENKEL, B.F.; BRILES, W.E.; BURKE, T.; BURT, D.W.; CRITTENDEN, L.B.; DODGSON, J.; HILLEL, J.; LAMONT, S.; PONCE DE LEON, A.; SOLLER, M.; TAKAHASHI, H.; VIGNAL, A. A consensus linkage map of the chicken genome. Genome Research, v.10, p.137-147, 2000.

HALEY, C.S.; KNOTT, S.A. A simple regression method for mapping quantitative trait loci in line crosses using flanking markers, Heredity, v.69, p.315-324, 1992.

HALEY, C.S.; KNOTT, S.A.; ELSEN, J.M. Mapping quantitative trait loci in crosses between outbred lines using least squares, Genetics, v.136, p.1195-1207, 1994. 
HAVESTEIN, G.B.; FERKET, P.R.; SCHEIDELER, S.E.; RIVES, D.V. Carcass composition and yield of 1991vs 1957 broilers when fed "typical"1957 and 1991 broiler diets. Poultry Science, v.73, p.1795-1804, 1994.

HILLEL, J. Map-Based quantitative trait locus identification. Poultry Science, v.76, p.1115-1120, 1997.

HILLEL, J.; PLOTZY, Y.; HABERFELD, U.; LAVI, U.; CAHANER,A.; JEFFREYS, A.J. DNA fingerprints of poultry. Animal Genetics, v.20, p.145-155, 1989.

HU J.; BUMSTEAD, N.; BARROW, P.; SEBASTIANI, G.; OLIEN, L.; MORGAN, K.; MALO, D. Resistance to salmonellosis in the chicken is linked to NRAMP1 and TNC. Genome Research, v.7, p.693-704, 1997.

IKEOBI, C.O.N.; WOOLLIAMS, J.A.; MORRICE, D.R.; LAW, A.; WINDSOR, D.; BURT, D.W.; HOCKING, P.M. Quantitative trait loci affecting fatness in the chicken. Animal Genetics, v.33, p.428-435, 2002.

JENNEN, D.G.J.; VEREIJKEIN, A.L.J.; BOVENHUIS, H.; CROOIJMANS, R.P.M.A.; VEENENDAAL, A.; VAN DER POEL, J.J.; GROENEN, M.A.M. Detection and localization of quantitative trait loci affecting fatness in broilers. Poultry Science, v.83, p.295-301, 2004.

KERJE, S.; CARLBORG, Ö.; JACOBSSON, L.; SCHUTZ, K.; HARTMANN, C.; JENSEN, P.; ANDERSSON, L. The twofold difference in adult size between the red junglefowl and White Leghorn chickens is largely explained by a limited number of QTLs. Animal Genetics, v.34, p.264-274, 2003. 
KIRKPATRICK, B.W.; MENGELT, A.; SCHULMAN, N.; MARTIN, L.C.A. Identification of quantitative trait loci for prolificacy and growth in mice. Mammalian Genome, v.09, p.97-102, 1998.

KNOTT, S.A.; MARKLUND, L.; HALEY, C.S.; ANDERSSON, K.; DAVIES, W.; ELLEGREN, H.; FREDHOLM, M.; HANSSON, I.; HOYHEIM, B.; LUNDSTRÕM, MOLLER, M.; ANDERSSON, L. Multiple marker mapping of quantitative trait loci in a cross between outbred wild boar and large white pigs. Genetics, v.149, p. 1069-1080, 1998.

LANDER, E.S.; BOTSTEIN, D. Mapping mendelian factors underlying quantitative traits using RFLP linkage maps, Genetics, v.121, p.185-199, 1989.

LANDER, E.; KUGLYAK, L. Genetic dissection of complex traits guidelines for interpreting and reporting linkage results. Nature genetics, v.11, p.241-247, 1995.

LEBOWITZ, R.J.; SOLLER, M.; BECKMANN, J.S. Trait-based analyses for the detection of linkage between marker loci and quantitative trait loci crosses between inbred lines. Theoretical and apllied genetics, v.73, p.556-562, 1987.

LEVIN, I.; CRITTENDEN, L.B.; DODGSON, J.B. Genetic map of the chicken Z chromosome using random amplified polymorphic DNA (RAPD) markers, Genomics, v.16, p.224-230, 1993.

LEVIN, I.; SANTAGELO, L.; CHENG, H.; CRITTENDEN, L.B.; DODGSON, J.B. An autossomal genetic linkage map of the chicken. Journal of Heredity, v.85, p.79$85,1994$. 
LIPKIN, E.; MOSIG, M.O.; DARVASI, A.; EZRA, E.; SHALOM, A.; FRIEDMANN, A.; SOLLER, M. mapping loci controlling milk protein percentage in dairy cattle by means of selective milk DNA pooling using dinucleotide microsatellite markers. Genetics, v.149, p.1557-1567, 1998.

LIU, B.H. Statistical genomics: linkage, mapping, and QTL analysis. Boca Raton: CRC Press, 1998. $611 \mathrm{p}$.

LYNCH, M.; WALSH, B. Genetics and analysis of quantitative traits. Sunderland: Sinauer Associates, 1998. $611 \mathrm{p}$.

McELROY, J.P.; HARRY, D.E.; DEKKERS, J.C.M.; LAMONT, S.J. Molecular markers associated with growth and carcass traits in meat-type chickens. In: WORLD CONGRESS ON GENETICS APPLIED TO LIVESTOCK PRODUCTION, 7, Montpellier, 2002. Proceedings. Montpellier: s.ed., 2002. (Session, 4: Poultry and rabbit breeding).

MICHELMORE, R.W.; PARAN, I.; KESSELI, R.V. Identification of markers linked to disease-resistance genes by bulked segregant analysis: A rapid method to detect markers in specific genomic regions by using segregating populations. Proceedings of the National Academy of Sciences USA, v.88, p.9828-9832, 1991.

MOODY, D.E.; POMP, D.; NIELSEN, M.K.; VAN VLECK, L.D. Identification of quantitative trait loci influencing traits related to energy balance in selection and inbred lines of mice. Genetics, v.152, p.699-711, 1999.

MUIR, W.M. Group selection for adaptation to multiple-hen cages: selection program and direct responses. Poultry Science, v.75, p.447-458, 1996. 
MURANTY, H. Power of tests for quantitative trait loci detection using full-sib families in different schemes. Heredity, v.76, p.156-165, 1996.

MURANTY, H. Selective genotyping for location and estimation of the effect of a quantitative trait locus. Biometrics, v.53, p.629-643, 1997.

MURANTY, H.; GOFFINET, B.; SANTI, F. Multitrait and multipopulation QTL search using selective genotyping. Genet. Res. Camb., v.70, p.259-265, 1997.

OHNO, Y.; TANASE, H.; NABIKA, T.; OTSUKA, K.; SASAKI, T.; SUZAWA, T.; MORII, T.; YAMORI, Y.; SARUTA, T. Selective genotyping with epistasis can be utilized for a mojor quantitative trait locus mapping in hypertension in rats. Genetics, v.155, p.785-792, 2000.

SAS INSTITUTE. SAS stat guide: release 6.03 edition. Cary, 1988, 1028p.

SEATON, G.; HALEY, C.; KNOTT, S.; KEARSEY, M.; VISSCHER, P. QTL Express: mapping quantitative trait loci in simple and complex pedigrees. Bioinformatics Applications Note, v.18, p.339-340, 2002. QTL Express: http://qtl.cap.ed.ac.uk/ (31 may 2003).

SEWALEM, A.; MORRICE, D.M.; LAW, A.; WINDSOR, D.; HALEY, C.S.; IKEOBI, C.O.N.; BURT, D.W.; HOCKING, P.M. Mapping of quantitative trait loci for body weight at three, six, and nine weeks of age in a broiler layer cross. Poultry Science, v.81, p.1775-1781, 2002. 
SIWEK, M.; CORNELISSEN, S.J.B.; BUITENHUIS, A.J.; NIEUWLAND, M.G.B.; BOVENHUIS, H.; CROOIJMANS, R.P.M.A.; GROENEN, M.A.M.; PARMENTIER, H.K.; VAN DER POEL, J.J. Quantitative trait loci for body weight in layers differ from quantitative trait loci specific for antibody responses to sheep red blood cells. Poultry Science, v.83, p.853-859, 2004.

SOLLER, M.; GENIZI, A; BRODY, t. On the power of experimental designs for the detection of linkage between marker loci and quantitative loci in crosses between inbred lines. Theoretical and Applied Genetics, v.47, p.35-39, 1976.

SPELMAN, R.; COPPIETERS, W.; KARIM, L.; VAN ARENDONK, J.A.M. Quantitative trait loci analysis for five milk production traits in chromososome six in Dutch Holstein-Friesian population. Genetics, v.144, p.1799-1808, 1996.

TATSUDA, K.; FUJINAKA, K. Genetic mapping of the QTL affecting body weight in chickens using a F2 family, British Poultry Science, v.42, p.333-337, 2001.

TAUTZ, D. Hypervariability of simple sequences as a general source of polymorphic DNA markers. Nucleic Acids Research, v.17, p.6463-6471, 1989.

TUISKULA-HAAVISTO, M.; HONKATUKIA, M.; VILKKI, J.; DE KONING, D.J.; SCHULMAN, N.F.; MÄKI-TANILA, A. Mapping of quantitative trait loci affecting quality and production traits in egg layers. Poultry Science, v.81, p.919927, 2002.

VALLEJO, R.L.; BACON, L.D.; LIU, H.C.; WITTER, R.L.; GROENEN, M.A. M.; HILLEL, J.; CHENG, H.H. Genetic mapping of quantitative trait loci affecting susceptibility to Marek's disease virus induced tumors in F2 intercross chickens. Genetics, v.148, p.349-360, 1998. 
VAN DER BEEK, S.; VAN ARENDONK, J.A.M.; GROEN, A.F. Power of two- and three-generations QTL mapping experiments in an outbred population containing full-sib and half-sib families. Theoretical and Applied Genetics, v.91, p. 11151124, 1995.

VAN KAAM, J.B.C.H.M.; VAN ARENDONK, J.A.M.; GROENEN, M.A.M.; BOVENHUIS, H.; VEREIJKEN, A.L.J.; CROOIJMANS, R.P.M.A.; VAN DER POEL, J.J.; VEENENDAAL, A. Whole genome scan for quantitative trait loci affecting body weight in chickens using a three generation design. Livestock Production Science, v.54, p.133-150, 1998.

VAN KAAM, J.B.C.H.M.; GROENEN, M.A.M.; BOVENHUIS, H.; VEENENDAAL, A.; VEREIJKEN, A.L.J.; VAN ARENDONK, J.A.M. Whole genome scan in chickens for quantitative trait loci affecting carcass traits. Poultry Science, v.78, p.1091-1099, 1999a.

VAN KAAM, J.B.C.H.M.; GROENEN, M.A.M.; BOVENHUIS, H.; VEENENDAAL, A.; VEREIJKEN, A.L.J.; VAN ARENDONK, J.A.M. Whole genome scan in chickens for quantitative trait loci affecting growth and feed efficiency. Poultry Science, v.78, p.15-23, 1999 b.

VIGNAL, A.; MONBRIN, C.; THOMPSON, P.; BARRE-DIRIE, A.; BURKE, T.; GROENEN, M.A.M.; HILLEL, J.; MAKI-TANILA, A.; TIXIER-BOICHARD, M.; WINNERS, K.; WEIGEND, S. Estimation of SNP frequencies in European chicken population. Abstract 27th International Conference on Animal Genetics, ISAG, 2000.

WELLER, J.I. Quantitative trait loci analysis in animals. Oxon: CABI Publ., 2001. $287 \mathrm{p}$. 
WELLER, J.I. Maximum likelihood techniques for the mapping and analysis of quantitative trait loci with the aid of genetic markers. Biometrics v.42, p.627640,1986

WELLER, J.I.; KASHI, Y.; SOLLER, M. Power of daughter and granddaughter designs for determining linkage between marker loci and quantitative trait loci in dairy cattle. Journal of Dairy Science, v.73, p.2525- 2537, 1990.

YONASH, N.; CHENG, H.H.; HILLEL, J.; HELLER, D.E.; CAHANER, A. DNA microsatellites linked to quantitative trait loci affecting antibody response and survival rate in meat-type chickens. Poultry Science, v.80, p.22-28, 2001.

ZENG, Z.B. Precision mapping of quantitative trait loci. Genetics, v.136, p.1457-1468, 1994.

ZHU, J.J.; LILLEHOJ, H.S.; CHENG, H.H.; POLLOCK, D.; SADJADI, M.; EMARA, M.G. Screening for highly heterozygous chickens in outbred commercial broiler lines to increase detection power for mapping quantitative trait loci. Poultry Science, v.80, p.6-12, 2001. 